ERNEST DRLANDI LAWRENCE BERKELEY NATIONAL LABIRATIRY

\section{A Survey and Critical Review of the Literature on Indoor Air Quality, Ventilation and Health Symptoms in Schools}

Joan M. Daisey and William J. Angell

Environmental Energy Technologies Division March 1998

\section{MASTER}

\section{REGEIVED}

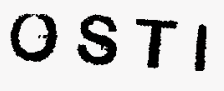




\section{DISCLAIMER}

This document was prepared as an account of work sponsored by the United States Government. While this document is believed to contain correct information, neither the United States Government nor any agency thereof, nor The Regents of the University of California, nor any of their employees, makes any warranty, express or implied, or assumes any legal responsibility for the accuracy, completeness, or usefulness of any information, apparatus, product, or process disclosed, or represents that its use would not infringe privately owned rights. Reference herein to any specific commercial product, process, or service by its trade name, trademark, manufacturer, or otherwise, does not necessarily constitute or imply its endorsement, recommendation, or favoring by the United States Government or any agency thereof, or The Regents of the University of California. The views and opinions of authors expressed herein do not necessarily state or reflect those of the United States Government or any agency thereof, or The Regents of the University of California.

Ernest Orlando Lawrence Berkeley National Laboratory is an equal opportunity employer. 


\section{DISCLAIMER}

Portions of this document may be illegible in electronic image products. Images are produced from the best available original document. 


\title{
A SURVEY AND CRITICAL REVIEW OF THE LITERATURE ON INDOOR AIR QUALITY, VENTILATION AND HEALTH SYMPTOMS IN SCHOOLS
}

\author{
Submitted to \\ Dr. Amy Arcus \\ Office of Environmental Health Hazard Assessment \\ California Environmental Protection Agency \\ Berkeley, California \\ by \\ Joan M. Daisey and William J. Angell ${ }^{\dagger}$ \\ Indoor Environment Program \\ Energy \& Environment Division \\ Lawrence Berkeley National Laboratory \\ Berkeley, CA 94720 \\ Indoor Air Quality Project \\ Minnesota Extension Service \\ University of Minnesota \\ St. Paul, MN 55108
}

March, 1998

This research was supported the California Environmental Protection Agency, Office of Environmental Health Hazard Assessments, under Contract No. 94-E0076 and by the Office of Energy Efficiency and Renewable Energy, Office of Building Technology, State and Community Programs, U.S. Department of Energy, under Contract No. DE-AC03-76SF00098. The statements and conclusions in this report are those of the contractor and not necessarily those of the California Air Resources Board. The mention of commercial products, their source or their use in connection with material reported herein is not to be construed as either and actual or implied endorsement of such products. 


\section{ACKNOWLEDGMENTS}

The authors wish to especially thank Bill Fisk, Lawrence Berkeley National Laboratory, and Dave Grimsrud, University of Minnesota, for their careful reviews of and thoughtful comments on the first draft of this report. Special thanks for Mark Mendell, NIOSH, for his assistance in providing copies of many of the HHERs, and to Al Blevins, County of Orange, Health Care Agency; John Fanning, Director, and Steven Ulhman, $\mathrm{CH}$, Department. of Environmental Health, Riverside, CA; and Michael Sibitz, Superintendent, Sylvan School District, Modesto, CA, for providing copies of a number of reports of investigations of California schools. These reports have provided unique and valuable information on indoor air quality and related health problems in California schools. Thanks also to Amy Arcus and Richard Lam, Office of Environmental Health Hazard Assessments, California Environmental Protection Agency, for initiating this review and for their assistance and support in the preparation this report.

This research was supported the California Environmental Protection Agency, Office of Environmental Health Hazard Assessments, under Contract No. 94-E0076 and by the Office of Energy Efficiency and Renewable Energy, Office of Building Technology, State and Community Programs, U.S. Department of Energy, under Contract No. DE-AC03-76SF00098. The statements and conclusions in this report are those of the contractor and not necessarily those of the California Air Resources Board. The mention of commercial products, their source or their use in connection with material reported herein is not to be construed as either and actual or implied endorsement of such products. 


\begin{abstract}
A survey and critical review were undertaken of existing published literature and reports on indoor air quality (IAQ), ventilation, and IAQ- and building-related health problems in schools, including California schools. Over 450 relevant publications were obtained and reviewed, including papers published in the archival peer-reviewed scientific literature, proceedings of scientific meetings, government reports, 77 NIOSH Health Hazard Evaluation Reports (HHER) and 70 reports on investigations of problem schools in California. Most of the reviewed literature was for complaint or problem schools.
\end{abstract}

The types of health symptoms reported in schools were very similar those defined as "sick building syndrome" (SBS) symptoms, although this may be due, at least in part, to the type of health symptom questionnaires used. Some of the symptoms, e.g., wheezing, are indicative of asthma. In the studies in which complaint and noncomplaint buildings or areas were compared, complaint buildings generally had higher rates of health symptoms.

Formaldehyde, total VOCs, $\mathrm{CO}$ and microbiological pollutants were the most commonly measured air pollutants in schools. Most of the formaldehyde measurements made in the U.S. were made in complaint schools but were generally below $0.05 \mathrm{ppm}$. Measurements of other pollutants were too limited to make conclusions as to the prevalence of indoor concentrations above levels of concern, even in problem schools. However, there is some evidence indicating that microbiological pollutants may be of particular concern. The few scientific studies on causes of symptoms in complaint schools indicate that exposures to molds and to allergens in schools contribute to asthma, SBS and other respiratory symptoms. Other indoor air pollutants, such as VOCs, aldehydes, etc., have been investigated to only a very limited extent, although there are reasons to suspect they may also contribute to health symptom prevalences in schools.

The major building-related problem identified was "inadequate ventilation with outside air." Several lines of evidence indicate that inadequate ventilation with outside air is a fairly common problem in schools in general, including those in Califormia. However, "inadequate ventilation" can only be considered an indicator, not the causal agent(s) for health symptoms reported in problem schools. Waterdamage to the building shells of schools, leading in turn to mold contamination and growth, was the second most frequently reported building-related problem. The root causes of many of the ventilation and water-damage problems in the schools was inadequate and/or deferred maintenance of school buildings and HVAC systems. However, in most studies, neither the building and ventilation systems problems nor specific pollutants have been clearly and unambiguously demonstrated to be causally related to the symptoms.

Although there is now considerable qualitative information on health complaints, ventilation and IAQ problems in complaint schools, we do not know what fraction of schools is experiencing IAQ and ventilation problems, and related health symptoms. There is also a lack of scientifically rigorous and quantitative information on the causal relationships between health symptoms, exposure, and dose response relationships that are needed to establish health standards for the protection of children in schools. Finally, the effectiveness and the costs and benefits of various remedial actions, undertaken to solve problems in specific schools, remain largely unknown. Recommendations to address these issues are made in this report. 


\section{LIST OF TABLES}

No.

Title

Page

4.1 California School Indoor Air Quality Reports, Number of Requests, Responses, and Reports Received

5.1 Comparison of Occupant Ratings of Environmental Comfort Conditions in HHERS for Schools and Office Buildings

5.2 Comparison of Faculty and Student Health Symptoms Experienced in Three New York Complaint Schools and a Control School in Percent ${ }^{2}$

5.3 Health Symptoms Over Four Weeks That Got Better When Away From Work of School Staff in Complaint and Non-Complaint Areas in Percent

5.4 Symptom frequencies among school personnel with wall-to-wall carpet in their workrooms in comparison with school personnel with hardwood floor coverings, 1982

6.1 Concentrations of $\mathrm{CO}_{2}$ Measured in U.S. and Canadian Schools and Reported in the Published Scientific Literature and Government Reports

6.2 Concentrations of $\mathrm{CO}_{2}$ Measured in European Schools and Reported in the Published Scientific Literature

6.3 Reported $\mathrm{CO}_{2}$ Measurements in California Schools from California Schools $\quad 40$ Reports

6.4 Outside Air Ventilation Rates Measured in Schools in the U.S. and Europe and 46 Reported in the Published Scientific Literature or Reports

7.1 Frequency of Airborne Pollutant Measurements by Study Group

7.2 Concentrations of TVOC Measured in U.S. and European Schools and Reported in Scientific Literature

7.3 Concentrations of Formaldehyde Measured in School Classrooms and Reported in the Published Scientific Literature

7.4 Summary of Reported Formaldehyde Measurements in California Schools 58

7.5 Measurements of Airborne Bacterial Counts in Schools Reported in the 61 Published Scientific Literature

7.6 Measurements of Allergens in Dusts Collected in Schools and Reported in the 64 Published Scientific Literature

7.7 Measurements of Airborne Fungi in U.S. and Canadian Schools Which Have 66

7.8 Measurements of Airborne Fungi in European Schools Which Have Been 68 Reported in the Published Scientific Literature 



\section{LIST OF FIGURES}

No.

Title

Page

1.1 Distribution of $\mathrm{CO}_{2}$ Measurements from 44 HHERs.

1.2 Comparison of the percent of HHERS and California schools reports reporting problems (among schools reporting) by type.

5.1 Types of Health and Environmental Complaints Cited in Request for Evaluation, 53 NIOSH School Health Hazard Evaluation Reports, 1981 1994

5.2 Health Symptom Prevalences and Perceived Environmental Deficiencies for 522 Respondents in 14 NIOSH School Health Hazard Evaluation Reports, 1993-1994.

5.3 Comparison of Pre-Investigative Health and Environmental Complaints for 35

California School Indoor Air Quality Investigations, 1988-1996, and 53 NIOSH School HHERs, 1981-1994.

8.1 Building Factors Associated with IAQ Problems, 49 NIOSH School Health Hazard Evaluation Reports, 1981 - 1994

8.2 Building Factors Associated with IAQ Problems, 37 California School Investigative Reports, 1988 - 1996 


\section{TABLE OF CONTENTS}

ACKNOWLEDGMENTS

ABSTRACT

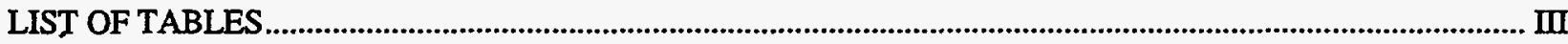

LIST OF FIGURES

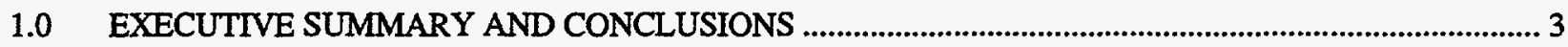

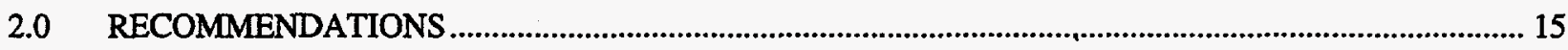

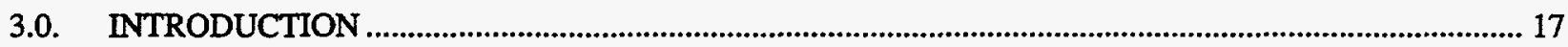

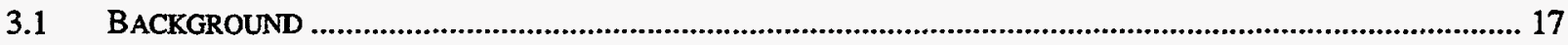

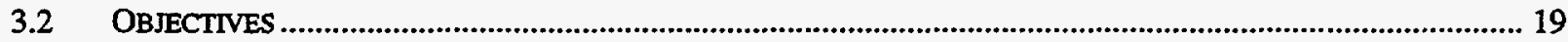

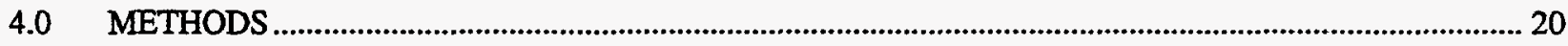

4.1 SEARCH OF THE PUBLISHED SCIENTIFIC LTERATURE

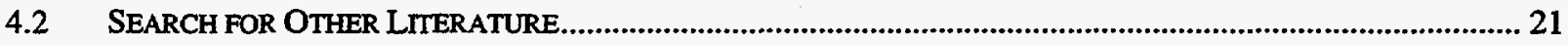

5.0 BUILDING-RELATED SYMPTOMS AND COMPLAINTS REPORTED FOR SCHOOLS IN THE

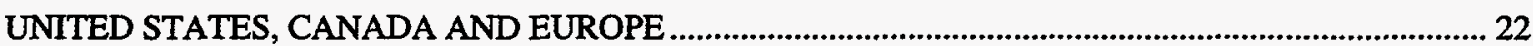

5.1 NATIONAL INSTITUTE FOR OCCUPATIONAL SAFETY AND HEALTH'S (NIOSH) HEALTH HAZARD

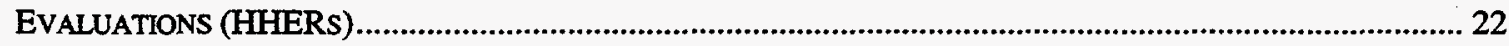

5.1.1 Types of Health and Environmental Complaints Prompting Evaluation.......................................... 23

5.1.2 Medical Evaluation Findings and Occupant Rated Environmental Conditions................................ 23

5.2 HEALTH SYMPTOMS AND ENVIRONMENTAL CONDITIONS IN SCHOOLS AS REPORTED IN THE PUBLISHED

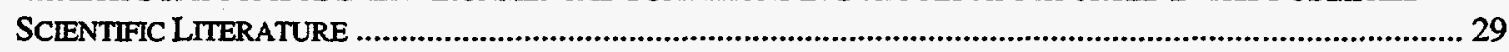

5.3 TYPES OF HEALTH AND ENVIRONMENTAL COMPLAINTS PROMPTING CALIFORNIA SCHOOL INVESTIGATIONS

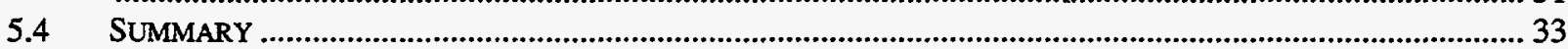

6.0 Measurements of Carbon Dioxide and Ventilation Rates in Schools............................................................... 34

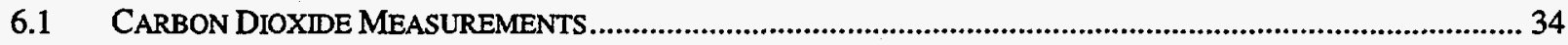

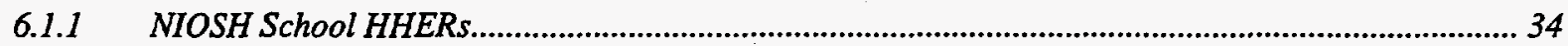

6.1.2 Publications in Scientific Journals, Conference Proceedings, and Government Reports ...................... 34

6.1.3 California School Indoor Air Quality Investigations........................................................................ 39

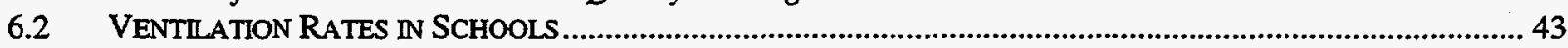

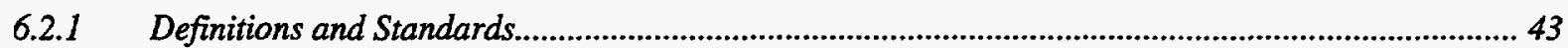

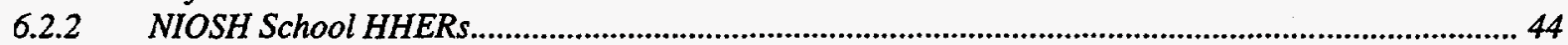

6.2.3 Publications in Scientific Journals, Conference Proceedings and Reports.................................... 44

6.2.4 California School Indoor Air Quality Investigations....................................................................4

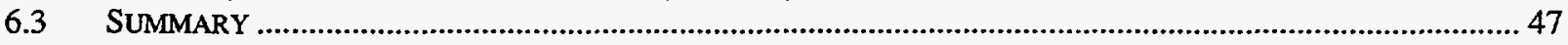

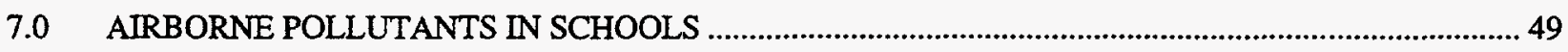

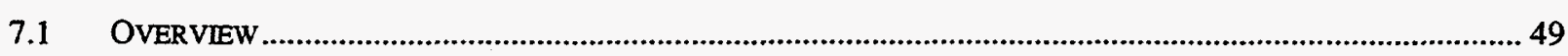

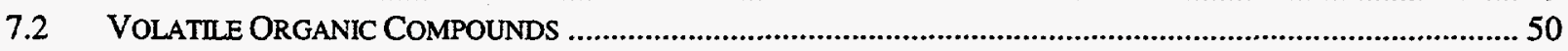

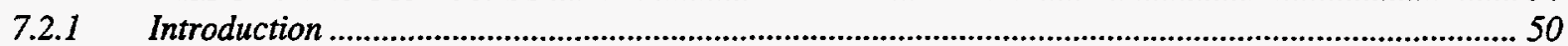

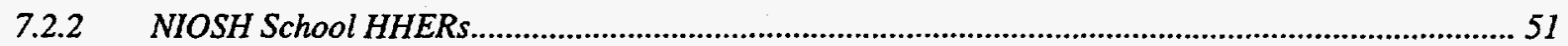

7.2.3 Publications in Scientific Journals and Conference Proceedings .................................................... 52

7.2.4 California School Indoor Air Quality Investigations........................................................................... 52 


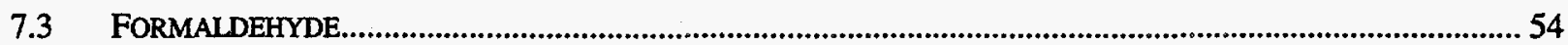

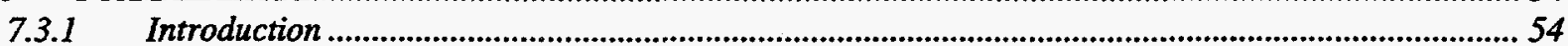

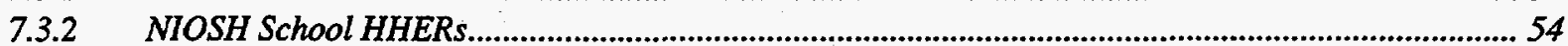

7.3.3 Publications in Scientific Journals and Conference Proceedings. ........................................................ 54

7.3.4 California School Indoor Air Quality Investigations.................................................................. 55

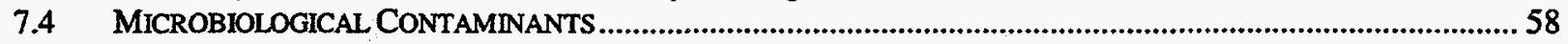

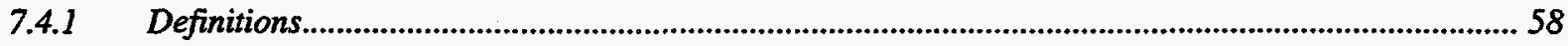

7.4.2 NIOSH School HHERs......................................................................................................................59

7.4.3 Publications in Scientific Journals and Conference Proceedings. ....................................................... 60

7.4.4 California School Indoor Air Quality Investigations.......................................................................... 68

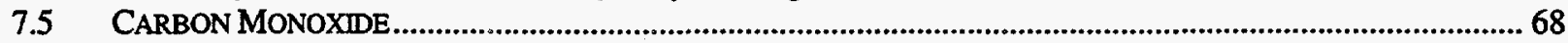

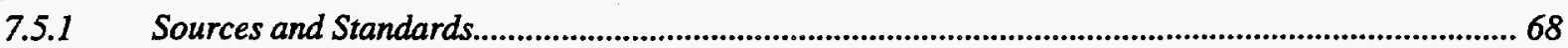

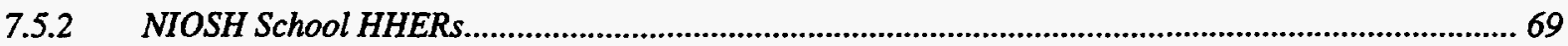

7.5.3 Publications in Scientific Journals and Conference Proceedings ....................................................69

7.5.4 California School Indoor Air Quality Investigations................................................................69

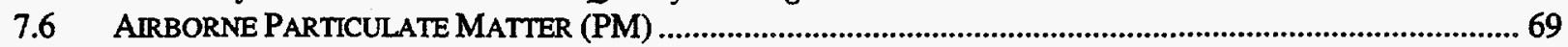

7.7 OZONE AND RELATED PHOTOCHEMICAL AIR POLLUTANTS ................................................................... 70

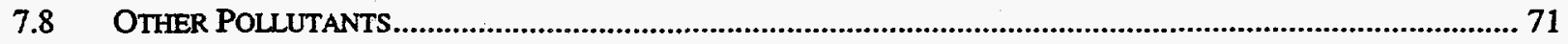

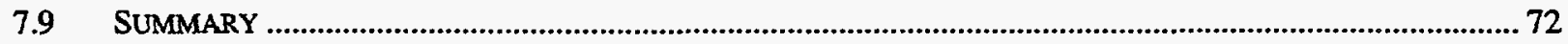

8.0 BUILDING CHARACTERISTICS ASSOCIATED WITH HEALTH COMPLAINTS .............................. 75

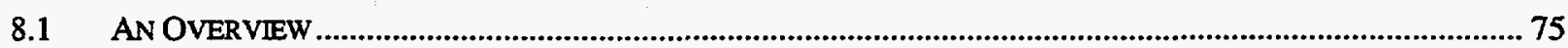

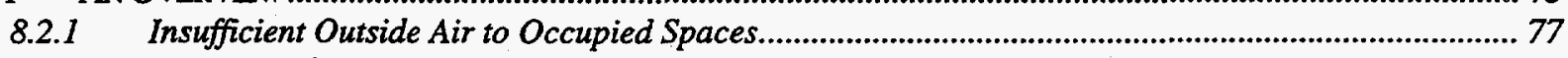

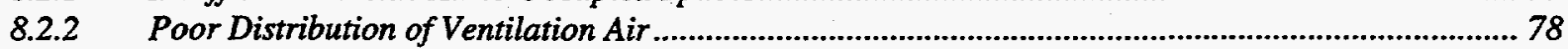

8.2.3 Poor Design of HVAC System...................................................................................................... 78

8.2.4 HVAC Operations-Related Ventilation Problems.................................................................................... 79

8.2.5 Service-Related Causes of Inadequate Ventilation ............................................................................. 79

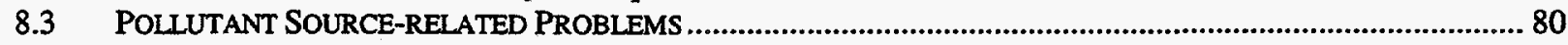

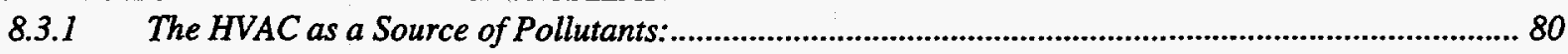

8.3.2 Water Leaks in the Building Shell ................................................................................................... 81

8.3.3. Inadequate Source Exhaust for Photocopiers, Kilns, and Other Special Sources.............................. 82

8.3.4 Carpeting as a Source of Indoor Air Pollutants ............................................................................... 82

8.4 MAINTENANCE OR RENOVATION ACTIVITIES WITHOUT SUFFICIENT CONTROL OF GENERATED AIRBORNE

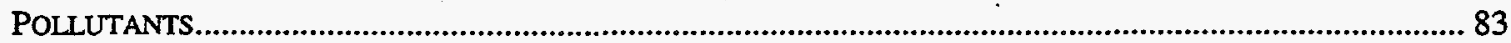

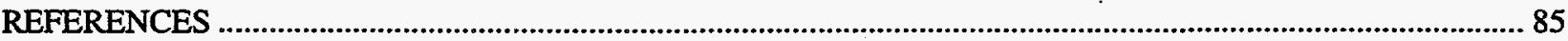

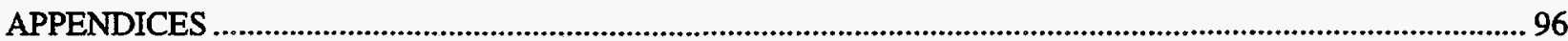




\subsection{EXECUTIVE SUMMARY AND CONCLUSIONS}

\section{Introduction}

A survey and critical review were undertaken of existing published literature and reports on indoor air quality (IAQ), ventilation, and IAQ- and building-related health problems in schools. Information on California schools, in particular, was sought. Since indoor air quality complaints are generally related to acute or more short-term health effects and symptoms, emphasis was placed on publications and reports of these types of health effects rather than chronic (or long-term) health effects such as cancer.

The objectives of this review were to:

1. Identify the most commonly reported building-related health symptoms involving schools;

2. Assemble, evaluate, and summarize existing measurement data on key indoor air pollutants most likely to be related to these symptoms, e.g., $\mathrm{CO}_{2}$, volatile organic compounds, bioaerosols;

3. Assemble and summarize existing measurements of ventilation rates in schools.

4. Summarize information on causes of indoor air quality and health symptom problems in schools.

\section{Some Background Facts}

- $36 \%$ of U.S. schools have reported heating, ventilating and air-conditioning (HVAC) systems as a "less-than-adequate building feature" while $19 \%$ reported indoor air quality problems in a nationwide assessment of school facilities (U.S. GAO, 1995a).

- $41 \%$ of California schools reported HVAC systems as less-than-adequate and $22 \%$ reported IAQ problems (U.S. GAO, 1995b).

- Indoor air quality (IAQ) problems are now the most common complaint made to the California Department of Education.

\section{Approach}

Over 600 publications on indoor air quality, ventilation and related health complaints in schools were identified through computer searches of a variety of bibliographic databases. These included papers published in the archival peer-reviewed scientific literature, proceedings of scientific meetings and government reports. A subset of approximately 450 of the most relevant publications were obtained and reviewed. The National Institute for Occupational Safety and Health (NIOSH) has conducted thousands of field investigations of possible health hazards in the workplace under authorization of the Occupational Safety and Health Act of 1970 . These field investigations are summarized in Health Hazard Evaluation Reports (HHER). Seventy-seven HHERs on investigations on indoor air quality and related health complaints in educational facilities were reviewed. These provided a national perspective on indoor air quality complaints and issues across 31 states, although half of these were from three states (Pennsylvania, Ohio, and West Virginia); none of the school HHERs was conducted in California.

In addition, 70 reports on IAQ investigations of schools in California were obtained through requests for information to various California state authorities. Fifty-six of the California reports originated from two southern California county health departments and the remainder were produced by environmental consultants. 
Health Symptom Complaints in Schools

Almost all of the complaints that prompted school HHERs were health related, although a small portion cited environmental conditions, especially odors. The health complaints were most often the same type that are classified as "sick building syndrome" (SBS) as defined by the World Health Organization (1979).
"Sick Building Syndrome" Symptoms

- Eye, nose or throat irritation

- Dry mucous membranes and skin

- Headaches

- Fatigue

- Dry or itchy skin

- Difficulty breathing or chest tightness

SBS symptoms are a spectrum of nonspecific complaints that occur during building occupancy and are absent or less severe when the individuals are not in the building.

In a subset of 14 HHERs, a standardized, self-administered, and detailed questionnaire was used to collect data from 552 occupants concerning health symptoms experienced at work during the last four weeks, that improved when away from the school building. The questionnaire also asked about environmental conditions experienced during the last four weeks at work as well as on the day the survey was completed. In general, the most commonly reported symptoms in these HHERs were eye, nose, and throat irritation, headaches, and unusual tiredness or fatigue. The prevalences of these symptoms ranged from $16 \%$ to $20 \%$ of the respondents. These symptoms were very similar to those that initially prompted the HHERs and to those associated with SBS (Malkin, et al., 1996). The questionnaire, however, was designed to elicit information on SBS-type symptoms. The prevalences of lower respiratory symptoms which improved when away from work (in the schools) ranged from $4 \%$ (wheezing, breathlessness, and chest tightness) to $8 \%$ for cough. Although the prevalences of lower respiratory symptoms were lower than for upper respiratory and central nervous symptoms, the lower respiratory symptoms may be more serious since they may be related to asthma.

A few of the HHERs (Gorman and Singal, 1984, Cantor and Lee, 1987, and Salisbury and Scharf, 1993) compared control populations in similar non-complaint schools or non-complaint areas in the same school. These all reported an overall higher frequency of health symptoms in the complaint school populations relative to the controls.

In contrast to the HHERS, the studies published in the archival literature on schools were generally initiated as research, rather than a response to a problem, and the purposes of the studies varied widely, e.g., to better understand the general causes of commonly reported symptoms such as SBS, or to characterize indoor concentrations of air pollutants.
NIOSH School HHERs

- Most investigations initiated in response to health complaints

- Health complaint questionnaire responses similar to the initial complaints that prompted the evaluations

- A pattern of health complaints similar to those reported for "sick building syndrome" (SBS)

- Higher rates of health symptoms found in complaint than noncomplaint buildings or areas

These studies utilized a variety of study protocols and often do not include very specific information on the symptoms or complaints of the building(s) occupants. Thus, quantitative comparisons of symptom reporting for studies published in the archival scientific literature with the HHERs is not possible. 
Qualitatively, however, the symptom complaints for school studies reported in the archival literature are very similar to those in the NIOSH HHERSs, i.e., SBS symptoms.

Some of the studies reported in the published scientific literature were conducted to elucidate the causes of SBS and other health effects, such as asthma, in problem schools and typically included control populations or pre- and post-mitigation measurements of symptoms. These studies indicate that exposures to molds and to allergens found in deposited dusts in schools are related to asthma, SBS and other respiratory symptoms. Other personal and psychosocial factors also contribute to symptom prevalences and must be accounted for in these studies. The effects of exposures to many other indoor air pollutants, such as VOCs, aldehydes, endotoxins in dust, etc., have been investigated to only a very limited extent, although there are reasons to suspect that these agents may also contribute in varying degrees to health symptom prevalences in schools.

In many of these epidemiological studies, actual exposures to molds, allergens, VOCs, etc., were not measured for the individuals, or were measured in indoor air for only very short time periods. In some studies, exposures were not measured at all, e.g., the presence of mold in a building was used as an indicator of exposure. Thus, the exposure- and dose-response relationships for SBS and other health symptoms are not well characterized and it is difficult to set scientifically based standards for health protection. Because of the lack of a quantitative understanding of exposure and response, it is not possible to estimate how much of a reduction in health effects and symptoms can be achieved for a given reduction in exposure to any given agent. Thus, the effectiveness (and cost-effectiveness) of various mitigation measures and exposure reduction measures remains highly uncertain.

All of the California schools investigations were conducted in response to some complaint or request for an investigation. Thirty-five of these listed occupant health symptoms and/or environmental complaints, including odors, which were identified in the request for the evaluation or were identified prior to the field environmental evaluation. The remaining California school reports were too general to classify, were pollutant specific, or the reports simply did not report any symptom or complaint. None of the California reports indicated that there were standardized medical evaluations using for example, written questionnaires. Thus, the prevalences of occupant health symptoms and environmental complaints cannot be assessed. However, the health symptoms described in the California school investigation reports bear a strong qualitative resemblance to the SBS character of the NIOSH school and office building HHERs.

\section{Measurements of Carbon Dioxide and Ventilation Rates in Schools}

Carbon dioxide is often used as a surrogate for occupant-generated pollutants, some of which are odorous, and as an indicator of the rate of outside air supply per occupant. Indoor concentrations above about $1000 \mathrm{ppm} \mathrm{CO}_{2}$ are generally regarded as indicative of indoor air quality that is unacceptable with respect to body odors. 
Forty-six of the HHERs reported $\mathrm{CO}_{2}$ measurements. In a third of these schools, 40 percent or more of the $\mathrm{CO}_{2}$ measurements were greater than $1000 \mathrm{ppm}$, as shown in Figure 1.1. In the archival literature, nine papers were found in which measurements of $\mathrm{CO}_{2}$ were reported for 25 schools in the U.S. or in Canada. In the schools with radon concentrations above $4 \mathrm{pCi} / \mathrm{L}$, reported $\mathrm{CO}_{2}$ concentrations were generally nẹar or above $1000 \mathrm{ppm}$.

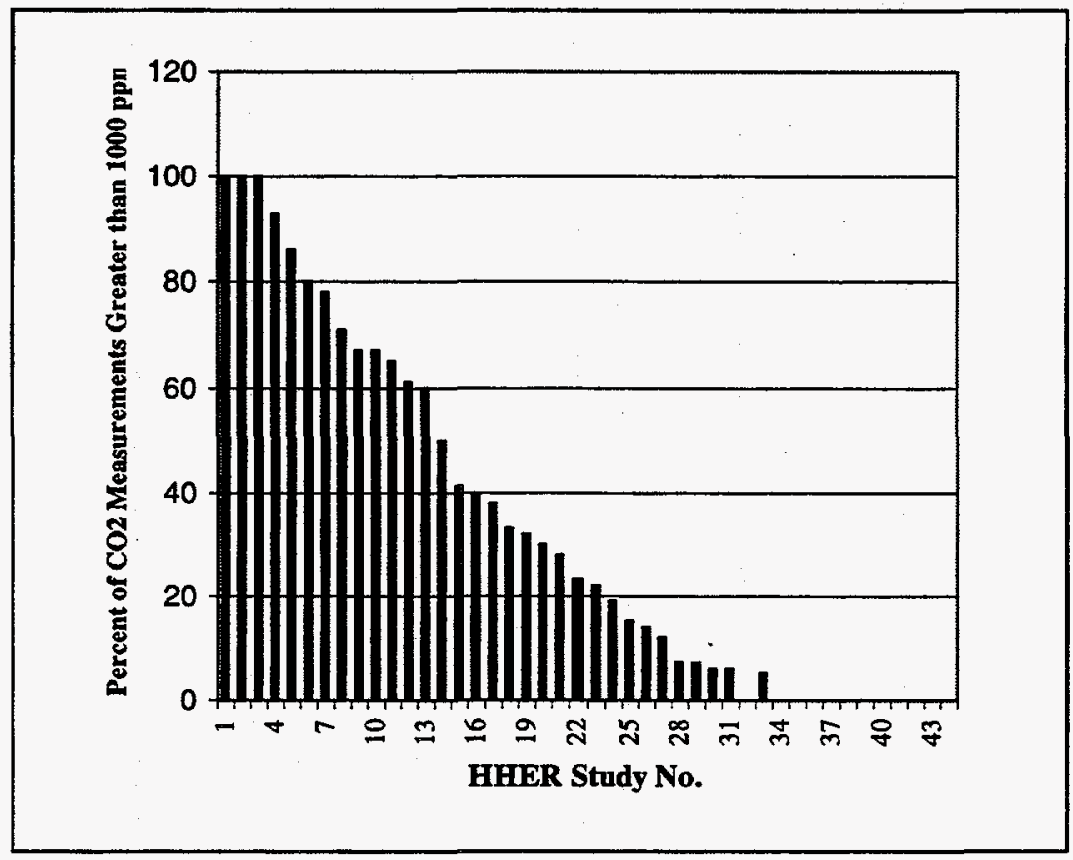

Figure 1.1 Distribution of $\mathrm{CO}_{2}$ Measurements from 44 HHERs.

Key to HHER Studies: 1. Burkhart, et al., 1992, 2. McManus, 1987b, 3. McManus, 1986, 4. Burr, et al., 1993, 5. Lee \& Hales, 1993a, 6. McManus, 1987a, 7. Martinez \& Ruder, 1993, 8. Zimmer \& Stayner, 1993, 9. Kaiser, 1988b, 10. Deitchman \& Fajen, 1993, 11. Berardinelli, 1994, 12. Burkhart \& Jennison, 1993, 13. Kiefer, et al., 1993, 14. Elliott \& Baron, 1989, 15. Blade \& Behrens, 1993, 16. Decker, 1993, 17. Mattorano, et al., 1993, 18. Roper \& Deitchman, 1988, 19. Donovan, 1994, 20. Daniels \& Connon, 1993, 21.Malkin \& Earnest, 1993, 22. Wilcox \& Crandall, 1987, 23. Bicknell, 1989, 24. Gunter, 1988, 25. Crandall \& Galson, 1987, 26. Elliott, 1988, 27. Sim \& Bryant, 1993, 28. Kinnes \& Bresler, 1993, 29. Blade, 1992, 30. Martinez, et al, 1992, 31. Kaiser \& Klincewicz, 1988, 32. Hanley, et al., 1992, 33. McCammon, 1991, 34. Lee \& Hales, 1993b, 35. Salisbury \& Scharf, 1993, 36. Bicknell, McManus, 1989, 37. Bryant, et al., 1989, 38. McManus, 1989a, 39. McManus, 1989b, 40. Gorman, 1988, 41. McManus, 1988, 42. McManus, 1987c, 43. Gorman, Tar-Ching, 1986, 44. Anderson \& Daniels, 1983.

In a draft paper, Bradstreet (unpublished) reported that concentrations of $\mathrm{CO}_{2}$ averaged $2300 \mathrm{ppm}$ for temporary (portable and site built) classrooms in non-complaint schools in Maine. Seventy-three percent of the $\mathrm{CO}_{2}$ measurements were above $1000 \mathrm{ppm}$ and 6 percent were above $5000 \mathrm{ppm}$. About half of the temporary classrooms had no mechanical ventilation and these averaged $2700 \mathrm{ppm}$.

Thirty-four of the California school indoor air quality investigations reported making $\mathrm{CO}_{2}$ measurements, although only 21 provided the measured concentrations. The range of reported $\mathrm{CO}_{2}$ concentrations in the California complaint schools was $300 \mathrm{ppm}$ to $4,000 \mathrm{ppm} \mathrm{CO}_{2}$, with one report of $11,500 \mathrm{ppm} \mathrm{CO}_{2}$. The $\mathrm{CO}_{2}$ concentrations were often in excess of $1000 \mathrm{ppm}$ in portable classrooms that had no outdoor air intakes or had ventilation systems that were off, with windows and doors closed due to fan or outdoor noise. 
The $\mathrm{CO}_{2}$ measurements in schools suggest that many classrooms have concentrations that exceed the guidelines of $1,000 \mathrm{ppm} \mathrm{CO}_{2}$, at least part of the time, and that this situation may be more acute in portable classrooms. However, there have not been any statistically based surveys of a random sample of classrooms that would provide information on the prevalence of high $\mathrm{CO}_{2}$ concentrations in schools on statewide, regional, or national basis.

Ventilation rates", the rates at which air is supplied and removed from an enclosed space by natural or mechanical means, have rarely been measured in schools. ASHRAE Standard 62-1989 (ASHRAE, 1989) recommends a ventilation rate of $15 \mathrm{cfm} /$ person $(7 \mathrm{~L} / \mathrm{s}$-person) for classrooms. This standard also specifies a maximum occupancy of 50 persons per $1000 \mathrm{ft}^{2}$ for schools. For typical occupancy, the current ASHRAE standard would require an air exchange rate of about 3 air changes per hour (ACH) for a classroom. One of the largest sets of ventilation rate measurements is for California schools (Lagus Applied Technology, 1995). Although this is not a random subset of schools, it is probably reasonably representative; furthermore, these were not complaint schools. The median ventilation rate measured in these 14 California schools during occupancy was $2.24 \mathrm{ACH}$. Nine of the schools had air change rates below $2.5 \mathrm{ACH}$.

For six non-complaint ${ }^{\S}$ schools in the Pacific Northwest for which measurements were made (Turk, et al., 1987), two out of six of the schools had whole building ventilation rates below the current ASHRAE Standard. Ventilation rates that have been reported for U.S. schools with high radon concentrations are also generally below the recommended rate, but it is not known how representative the high radon schools are of schools in general.

A substantial fraction of the schools in which there was evidence of elevated $\mathrm{CO}_{2}$ concentrations and/or inadequate ventilation rates were non-complaint schools. Furthermore, ventilation was one of the conditions most frequently reported to be unsatisfactory in the U.S. GAO (1995a, b) survey of U.S. schools, in which $41 \%$ of California schools reported HVAC systems as less-than-adequate and $22 \%$ reported IAQ problems. The measurement data and the results of the survey indicate that inadequate ventilation may be a fairly common problem in schools, including those in California.

\footnotetext{
* Ventilation rate is used here to refer only to the rate at which outside air is supplied to the occupied space and does not include recirculated air.

$\S$ Non-complaint schools are defined as those in which the study was not undertaken in response to a problem.
} 


\section{Airborne Pollutants in Schools}

The most commonly measured air pollutants in schools, other than $\mathrm{CO}_{2}$, have been the volatile organic compounds (VOCs) (including total VOCs or TVOC), formaldehyde, $\mathrm{CO}$ and microbiological pollutants, including bioaerosols. However, even among problem schools, such measurements have not been made in the majority of cases. Several publications on the penetration of outdoor criteria pollutants into indoor air, airborne particulate matter and ozone, were also reviewed.

TVOC measurements were reported in 27 of 77 NIOSH school HHERs. Of these, many were below the limits of detection or were similar to typical indoor concentrations that have been reported in homes (Wallace, et al., 1991). In some HHERs, TVOC concentrations have been reported which are in the range in which SBS symptoms such as eye, nose, and throat irritancy and headaches might be expected (Molhave, 1990). For these HHERs, high TVOC concentrations were associated with high emission indoor sources such as liquid-based photocopiers, floor mastic and painting.

In nine of the California schools, measurements were made of individual VOCs or of TVOC, with the highest TVOC concentration of $2.9 \mathrm{mg} / \mathrm{m}^{3}$ reported for a portable classroom. At this concentration, some of the occupants might have experienced eye, nose and throat irritation and other SBS symptoms. None of the reported measurements of individual VOCs were unusual relative to typical indoor air concentrations reported in homes.

Formaldehyde is classified separately from the VOCs and TVOC because the sampling and analysis for this compound requires a different method. This compound is widely used in the manufacture of building materials, e.g., particleboard, furnishings, and has sometimes been found in indoor air at levels that can cause eye, nose and throat irritation as well as lower airway and pulmonary effects. The World Health Organization (WHO, 1987) indoor air quality guideline for formaldehyde is $100 \mu \mathrm{g} / \mathrm{m}^{3}(0.08 \mathrm{ppm})$ for a 30 minute exposure, based on annoyance (irritant) effects. The Canadian target level (acceptable level) for formaldehyde in residential indoor air is $0.05 \mathrm{ppm}$ (Canada Department of National Health and Welfare, 1987). The California Department of Health Services (DHS, 1983) has also recommended that indoor concentrations of formaldehyde in non-industrial settings should not exceed $0.05 \mathrm{ppm}$.

There have been many more measurements of formaldehyde than of TVOC made in schools, although, surprisingly, formaldehyde measurements were reported for only 15 of the 77 HHERs investigations. Of this set, less than $20 \%$ exceeded $0.05 \mathrm{ppm}$. For California schools, formaldehyde measurements were made for 16 schools, including some in portable buildings. The formaldehyde concentrations were almost all below $0.05 \mathrm{ppm}$. However, since formaldehyde is highly irritating, and the measurements have been quite limited, it would be wise to measure both formaldehyde and other higher molecular weight aldehydes in cases where there are irritant complaints and/or any possibility of elevated concentrations. Certain aldehydes, $\mathbf{n}$-pentanal, $\mathbf{n}$-hexanal, $\mathbf{n}$-heptanal, which have been found at very high concentrations in some newly constructed residential buildings, may also be present in newly constructed schools.

"Microbiological contaminants" or "bioaerosols" refers to a diverse variety of microbiological agents that have been found in indoor environments and can cause human diseases and adverse health effects. The major classes of microbiological pollutants of concern which were considered in this review were: (1) bacteria; (2) allergens, including house dust mite allergens and allergens from animal dander, and (3) fungal spores. Although there is reason to suspect that airborne microbiological pollutants may be a 
significant factor in causing adverse health effects often observed in complaint schools, the sampling and analysis methods which have been developed and used to date severely limit our ability to characterize exposures to these agents in a way that is useful for understanding cause and effect. Standards against which to assess measurements are also not well developed with respect to dose and response.

Despite these limitations, the measurements that have been reported provide some valuable insights. In the case of airborne bacteria, for which humans are a major source, high levels are suggestive of high occupancies and inadequate ventilation. One of the largest databases of measurements of bacteria is for 150 classrooms in 40 California schools with complaints (Gallup, et al., 1993). The average airborne bacterial count for these classrooms when occupied was 2,345 colony forming units $(\mathrm{CFU}) / \mathrm{m}^{3}$, twice the $1000 \mathrm{CFU} / \mathrm{m}^{3}$ level which Morey (1984) suggested as indicative of possible microbial contamination and warranting further investigation. At the upper end of the range, concentrations as high as $18,432 \mathrm{CFU} / \mathrm{m}^{3}$ were reported for these California schools. These data suggest again that a significant fraction of California schools may not have the ventilation rates needed to remove and dilute the indoor concentrations of airborne bacteria and viruses which can cause infectious diseases, e.g., influenza, colds, tuberculosis.

The existing literature also indicates that there is a significant potential for exposures to allergens such as house dust mite, cat and dog allergens, and molds in re-suspended dusts from carpeted and uncarpeted floors and other surfaces in schools. The climate of coastal California is one in which house dust mites might be expected to flourish. Studies in European schools have shown that dust mite allergen and cat and dog allergens can be found in schools, the latter two brought in on the clothing of children and teachers who have pets. There is evidence to suggest that carpeted floors may be a greater reservoir for such allergens than uncarpeted floors. However, there is also evidence from a study in Florida that good cleaning practices can substantially reduce levels of these allergens. Since approximately $5-10 \%$ of children are asthmatic and may be sensitive to one or more of these allergens, or to cockroach allergen, the presence of such allergens in schoolrooms could pose a significant health risk with respect to asthma attacks.

Mold growth can also be a problem when there is water damage from leaks or flooding, or mold growth in wet sections of HVAC systems. A significant fraction of the population is allergic to molds. In addition, some molds are highly toxigenic and, even when non-viable, may contain endotoxins which can cause serious health problems. The potential for exposure to molds is probably best assessed through examinations of buildings for evidence of mold growth rather than more costly but less effective air sampling.

Carbon Monoxide. Carbon monoxide (CO) is regulated as an outdoor Criteria Air Pollutant for which the 8-hour standard is $9 \mathrm{ppm}$. Sources in indoor air include outdoor air, malfunctioning heating appliances, vehicle exhaust from attached garages or loading docks located near building air intakes. Exposures to very high concentrations can lead to coma and death within minutes. Exposures at lower concentrations can cause headaches and nausea.

Carbon monoxide was measured in 12 of $77(16 \%)$ the HHERs and was generally near or below the limit of detection. In the archival literature, $\mathrm{CO}$ has not generally been found at concentrations of concern in schools. In the California school reports, 3 of the reports presented $\mathrm{CO}$ measurements; one reported 5 $\mathrm{ppm}$ in a classroom that was not continuously ventilated as required by state regulation. In general, the 
reported measurements of carbon monoxide in schools are very limited but suggest that the source of this pollutant in many schools is outdoor air.

Penetration of Outdoor Air Pollutants into Schools. Finally, the penetration of outdoor air pollutants, such as $\mathrm{CO}$, particulate matter (PM) and ozone, into schools may also be important in areas with high outdoor air concentrations. The penetration of PM-2.5 into buildings, along with ventilation air, is typically quite high. Thus children attending schools near major freeways may be exposed to airborne particulate matter at levels similar to those outdoors. A recent report by Brunekreef, et al. (1997) raises concerns about the potential impact of outdoor airborne particulate matter ${ }^{1}$ in schools located near major highways. These investigators found decrements in the lung function of children living near and attending schools located near major highways in the Netherlands. They also reported that truck traffic density and black smoke concentrations were associated with increased reporting of chronic respiratory symptoms.

Ozone is largely an outdoor air pollutant but penetrates into buildings via infiltration and active ventilation. Subsequent depositional losses to indoor surfaces reduce indoor concentrations of ozone to varying degrees. However, if the ventilation rate with outdoor air is very high, indoor concentrations can be very close to outdoor concentrations (Weschler, et al., 1989; Stock and Venso, 1993). Ozone is a strong irritant and high concentrations are common in outdoor air in many parts of California during late spring, summer and early fall. Photocopiers and laser printers can be additional sources of ozone in indoor air if filters in these devices are defective, overloaded by heavy use, or are not properly installed and maintained.

Ozone was not measured in any of the HHERs nor was it reported in any of the more recently published scientific papers. However, $\mathrm{O}_{3}$ measurements were reported in three of the California school investigations. The measurement results in two of the investigations were less than the lower limit of detection. In the third case, the result was $0.7 \mathrm{ppm}$. The ambient one-hour outdoor air standard for $\mathrm{O}_{3}$ is $0.12 \mathrm{ppm}$. This case involved office worker complaints of headaches, sore throats, eye and respiratory irritation, and cough that coincided with the arrival of a new laser printer. The printer had a defective filter.

Building Characteristics Associated with Health Complaints. Ideally, every building investigation would identify a specific pollutant or physical agent causing the indoor environmental complaints or occupant health symptoms and would measure changes in air pollutant levels and in symptom prevalences as a consequence of some remediation. Typically, however, building investigations identify certain building characteristics or problems that are likely to be associated with the complaints or symptoms, correct these, and assume that the remediation will mitigate the symptoms.

The most commonly cited building characteristics associated with indoor environmental complaints in the NIOSH HHERs and in the California schools reports are shown and compared in Figure 1.2. These fall into three broad categories:

- Ventilation system-related problems (including inadequate ventilation, inadequate source exhaust, poor distribution or balance of air, and poor HVAC maintenance)

\footnotetext{
${ }^{1}$ Airborne particulate matter from outdoor air is brought into buildings with ventilation air; typical penetration factors for PM2.5 are about 0.8 to 0.9 .
} 
- Water leaks in building shells

- Maintenance and renovation-related problems

Again it must be emphasized that these investigations were not intended or designed as scientific investigations of cause and effect, i.e., there were no follow-up measurements to determine if symptoms were reduced by the corrective measures. None the less, the results are consistent with the results of the GAO survey (U.S. GAO, 1995 a, b)in which $36 \%$ of the schools reported HVAC systems as "less than adequate" and $19 \%$ reported indoor air quality problems.

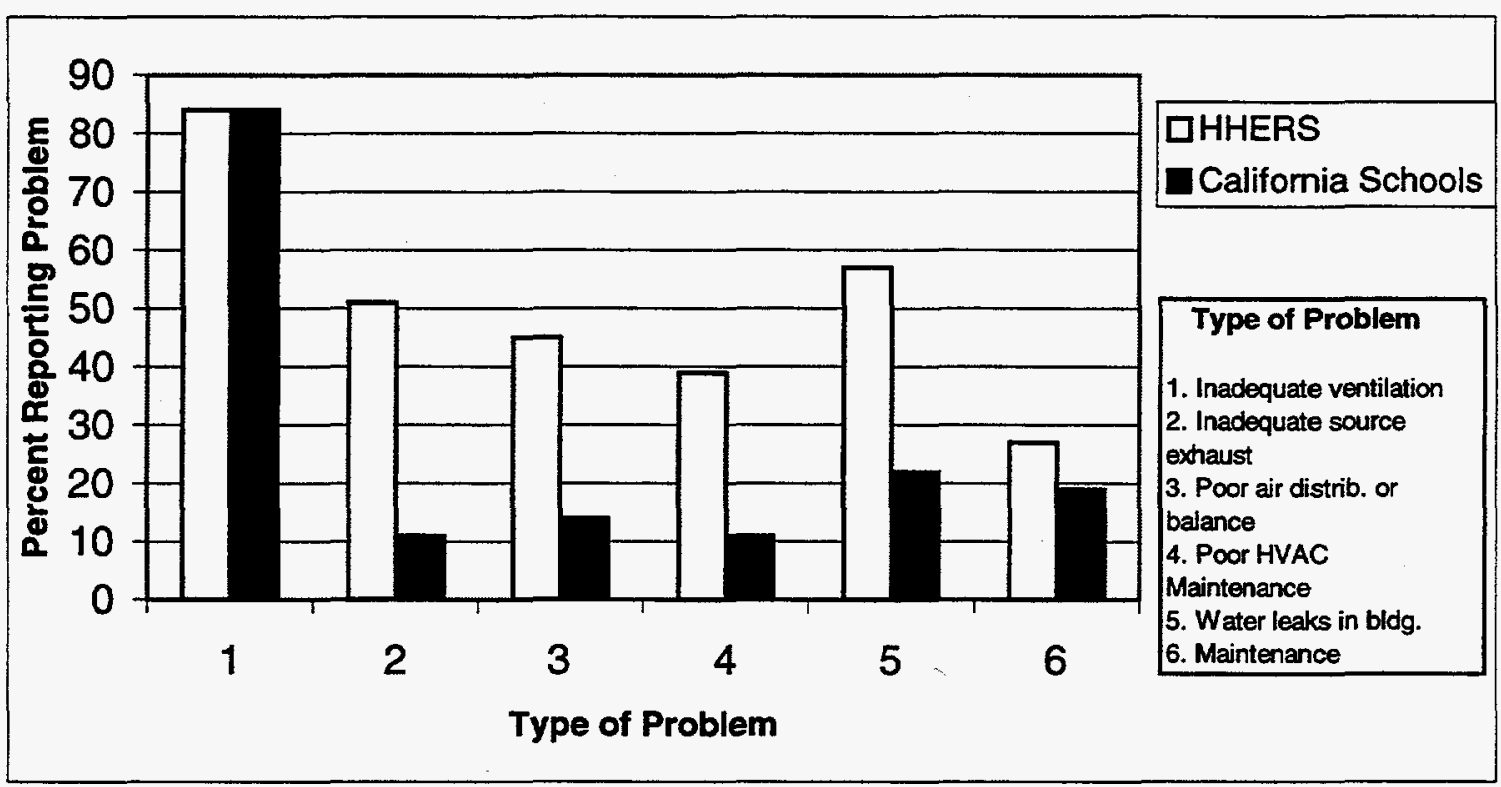

Figure 1.2. Comparison of the percent of HHERS and California schools reports reporting problems (among schools reporting) by type.

Ventilation System-related Problems. In the NIOSH HHERs, the most common building factors associated with indoor environmental complaints were related to the ventilation system, with insufficient outdoor air being supplied to the occupied space the most frequently cited problem (84\%). This was also the most common building factor identified as a problem in the California schools investigations. Califomia school investigators frequently found that ventilation would only be provided to classrooms and other occupied space when there was a call for heating or cooling. Furthermore, if the fan in the system could be operated manually to bring in ventilation air, it was often turned off because the noise of the fan made it difficult for the teacher and students to hear.

Half of the HHERs that identified building factors associated with indoor air quality problems cited inadequate spot exhaust of pollutant generating activities, e.g. use of a household-type bathroom exhaust fan as the only means to vent combustion products from a kiln, no exhaust ventilation for woodworking equipment in the industrial arts classroom. California school investigations found similar cases that were associated with indoor air quality problems. 
Poor distribution or balancing of ventilation air was also a commonly cited ventilation problem in the HHERs (45\%) and the California schools reports (14\%). Among the HHERs, examples of poor air distribution or poor air balancing included one classroom with $2000 \mathrm{ppm}$ of $\mathrm{CO}_{2}$ while the other classrooms had concentrations below 1000 ppm (McCammon, 1990).

In both the NIOSH HHERs and the California Schools Reports, problems due to poor design of HVAC systems were frequently cited. These included systems in which outside air dampers were not accessible, insulation on the outside of a main air handling unit (AHU) that blocked access to the coils, and access to filters blocked by pipes and ducts.

In a substantial number of problem schools, poor HVAC maintenance led to contamination of the system and the HVAC system became a source of air pollution. Nineteen of the 49 (39\%) of the NIOSH school HHERs and 4 of $37(11 \%)$ California school investigations cited poor maintenance of the heating, ventilation and air condition system as a factor in indoor air quality problems.

Water Leaks in Building Shells. The second most commonly cited building factor in the NIOSH HHERS and the California schools reports was water leaks in the building shell. This factor is frequently associated with mold contamination and may be classified a pollutant source-related building problem. Water leaks were reported in 28 (of 49) HHERs and 8 (of 37) of the California school investigations. The HHERs cases included mold contamination of ceiling tiles from a roof leak that occurred during reconstruction of the roof; numerous roof leaks and broken, missing, and water-stained ceiling tiles that existed for five years and that were so severe that classes were canceled; and mold and mildew associated with a chronically leaking roof in a windowless Florida elementary school. The Califormia school investigations included standing water under a portable classroom, roof drains connected to the crawlspace of a school (which filled with water when it rained), and a carpeted school classroom that had been flooded due to surface run-off.

Maintenance and Renovation Activity-related Problems. Thirteen of the HHERs and 7 of the California school investigations reported indoor air quality problems associated with maintenance and renovation or other construction-related activity that was carried out without adequate control of pollutants that were generated by those activities. The HHERs cases included maintenance personnel that used a turpentine solution to remove gum from a carpet and complaints about burning eyes, headaches, nausea, and respiratory problems following application of coal tar to the roof of an occupied school. The California reports included application of caulk to a roof-mounted air handler while the school was occupied and the air handlers were in operation and use of a highly irritating chemical agent to facilitate drying and inhibit microbial growth in a school classroom carpet that had been flooded. The chemical agent was recommended for use in well-ventilated areas. 


\section{Conclusions}

- The vast majority of the literature reviewed for this report was for complaint or problem schools. There is a lack of information on the fraction of schools experiencing building-related health symptoms and ventilation and indoor air quality problems.

- In general, the types of symptoms reported in the NIOSH HHERs and the California schools investigations are very similar those defined as SBS symptoms, although this may be due, at least in part, to the type of health symptom questionnaires used in the HHERs. Some of the symptoms, e.g., wheezing, are probably related to asthma. In the few HHERs in which complaint and noncomplaint buildings or areas were compared, higher rates of health symptoms were found in the complaint buildings or areas. The symptom complaints for school studies reported in the published scientific literature are also very similar qualitatively to those in the HHERs.

- Studies conducted to elucidate the causes of SBS and other health effects, such as asthma, indicate that exposures to molds and to allergens found in deposited dusts in schools are related to asthma, SBS and other respiratory symptoms. Personal and psychosocial factors have also been found to contribute to but do not completely account for symptom prevalences in these studies. The effects of exposures to many other indoor air pollutants, such as VOCs, aldehydes, endotoxins in dust, etc., have been investigated to only a very limited extent, although there are reasons to suspect that these agents may also contribute in varying degrees to health symptom prevalences in schools.

- Measurements of airborne pollutants in schools have been very limited. In addition, there are often differences in sampling protocols and analysis methods among different investigators. The most commonly measured air pollutants in schools include formaldehyde, TVOC, $\mathrm{CO}$ and microbiological pollutants. Most of the formaldehyde measurements made in the U.S. were made in complaint schools but were generally below $0.05 \mathrm{ppm}$, the level which the California Department of Health Services (DHS, 1983) has recommended should not be exceeded in non-industrial indoor settings. The TVOC and CO measurements were too limited to make conclusions as to the prevalence of indoor concentrations above levels of concern, even in problem schools.

- Measurements of microbiological pollutants, including bacteria, house dust mite allergens, cat and dog allergens, and molds, have also been very limited, due in part to the lack of adequate sampling and analysis methods. There is some evidence indicating that these pollutants may be causally related to the health symptoms reported in complaint schools.

- The major building-related problem identified is "inadequate ventilation with outside air," with several lines of evidence supporting the conclusion that inadequate ventilation with outside air is a fairly common problem in schools, including those in California. However, "inadequate ventilation" can only be considered an indicator, not the causal agent(s) for health symptoms reported in problem schools.

- The second most common building-related problem identified was water-damage to the building shells of schools, leading in turn to mold contamination and growth. The root cause of many of the ventilation and water-damage problems in the schools was inadequate and/or deferred maintenance of school buildings and HVAC systems. 
- Although there is now considerable qualitative information on health complaints, ventilation and IAQ problems in problem schools, we do not know what fraction of schools is experiencing IAQ and ventilation problems, and related health symptoms. There is also a lack of scientifically rigorous and quantitative information on the causal relationships between health symptoms, exposure, and dose response relationships that are needed to establish health standards for the protection of children in schools. Finally, the effectiveness and the costs and benefits of various remedial actions, undertaken to solve problems in specific schools, remain largely unknown. 


\subsection{RECOMMENDATIONS}

1. Survey of California Schools. A random survey of California schools is recommended to determine the prevalences of school building-related health symptoms, and ventilation and indoor air quality problems for California schools, in general, not just problem schools, and to characterize the true extent of these problems for purposes of planning mitigation.

The vast majority of the literature reviewed for this report was for complaint or problem schools. Thus, there is not adequate information on the prevalences of school building-related health symptoms and ventilation and indoor air quality problems. A random survey should use a questionnaire designed to elicit information on the prevalences of SBS symptoms, allergy and asthma, and infectious respiratory illnesses, and on building factors which might be causally related to these. In addition, some measurements of $\mathrm{CO}_{2}$ and other potential pollutants and inspections of HVAC systems should be made on random sub-sample of these schools to more objectively characterize potential ventilation problems and obtain information of the prevalence of these problems.

2. Standardized Protocol. A standardized protocol for investigations of complaints in schools should be developed and tested, and made available to California schools.

A standardized protocol would be of use to staff in Departments of Health who must investigate and resolve these problems when they arise, and to school districts who must deal with such problems. The use of a standardized protocol would also provide information that would be more comparable across schools for broader analyses and surveillance of these kinds of problems.

3. Purchase Specifications for Portables. Purchase specifications for portable buildings should include requirements for HVAC systems that operate to supply ventilation air even when there is no need for heating or cooling. In addition, the specification should require low noise fans for the HVAC systems.

Review and analysis of the California schools reports indicated that a common problem in portable buildings is HVAC systems that supply ventilation air only when heating or cooling is required. They also included reports of teachers turning off noisy ventilation systems so they could be heard by the students.

4. Commitment to Repair and Maintain School Buildings. A commitment should be made to provide the funding required for long deferred repairs in school buildings, e.g., repairs of water damage and HVAC systems, and for ongoing maintenance of buildings to meet existing standards.

The GAO survey of school facilities indicated that a root cause of many of the ventilation and air quality problems in schools is deferred maintenance. 
5. Research Needs. Research is needed to :

Determine, in a more quantitative way, the degree to which IAQ problems in schools increase asthma, SBS symptoms and absentee rates of students;

$>$ Identify the specific agents which cause the health effects and determine the exposure- and dose-response relationships for those pollutants which are the most significantly related to health symptoms.

$>$ Determine if learning (e.g., test scores) can be significantly increased through improved indoor air quality;

$>$ Determine the cost-effectiveness of various remediation measures undertaken to solve problems in complaint schools through intervention studies in which changes in health symptoms and test scores are measured before and after remediation;

$>$ Determine the costs of deferred building maintenance with respect to health and learning in students;

$>$ Determine the viability of using $\mathrm{CO}_{2}$ and other types of sensors ${ }^{\dagger}$ to routinely control ventilation and to provide an indication of low ventilation;

$>$ Develop improved sampling and analysis methods for bioaerosols;

$>$ Develop low cost samplers for measuring 6-hour exposures to other key indoor pollutants, such as aldehydes, which may be contributing to the kinds of symptoms observed in problem schools.

\footnotetext{
The cost of some $\mathrm{CO}_{2}$ sensors is only a few hundred dollars.
} 


\subsection{INTRODUCTION}

\subsection{Background}

It is well recognized that a high-quality school environment is essential for education. Congress passed the Education Infrastructure Act of 1994 (as part of the Improving America's Schools Act, P.L. 103-382, October 20, 1994) in an effort to improve school facilities. A recent United States (U.S.) Government Accounting Office (U.S. GAO, 1995a, b) survey of school facilities in the U.S. suggests that ventilation and indoor air quality are significant problems, in general, in schools. Thirty-six percent of the schools reported heating, ventilating and air-conditioning (HVAC) systems as a "less-than-adequate building feature" while $19 \%$ reported indoor air quality problems. By comparison, $41 \%$ of California schools reported HVAC systems as less-than-adequate and $22 \%$ reported IAQ problems (U.S. GAO, 1995b). Furthermore, nationally, there appears to be evidence that that there is an association between unsatisfactory school IAQ and the proportion of the school's students from low-income households, i.e., in U.S. schools with less than $20 \%$ of the students eligible for reduced price lunch, $16 \%$ have unsatisfactory IAQ while in U.S. schools with $70 \%$ or more of the students eligible for reduced price lunch, 23\% have unsatisfactory IAQ (U.S. GAO, 1996).

In addition to Congress, states have increasingly addressed issues involving indoor air quality in schools. At least 14 states regulate one or more environmental factors related to indoor air quality in schools including: pesticide application in schools (Arizona, Louisiana, Michigan, Montana, Tennessee, and Texas); urea formaldehyde insulation in any building (California and Connecticut); ventilation standards in schools, public buildings, or workplaces (California, Connecticut, Maine, New Jersey, and New Hampshire); mandatory consideration of indoor air quality in school energy conservation efforts (California and Maine); state review or evaluation of school indoor air quality (Florida, Maine, and New Hampshire); state assistance to local health departments in adopting indoor air quality in programs in public buildings (Wisconsin); and mandatory school indoor air quality programs and best practices requirements to improve indoor air quality in new school buildings (Washington) (Environmental Law Institute, 1996).

In the state of California during October 1995, 5.5 million students and over 200,000 teachers occupied approximately 175,000 classrooms in 7,900 schools serving kindergarten through 12th grade (K-12) according to data available from the California Department of Education (1995) and the U.S . Department of Education (1996). Indoor air quality (IAQ) problems are now the most common complaint made to the California Department of Education. There have been several schools with such serious air quality problems that they have come to the combined attention of the California Department of Education, the California Department of Health Services, the California Air Resources Board, and the Indoor Air Risk Assessment Group (IARAG) of the California Environmental Protection Agency.

Portable or relocatable buildings, which are in wide use in California, are suspected to have more air quality problems than conventionally-built schools due to a number of factors such as: the materials used in construction, air-tightness, ventilation characteristics, and other factors. There are 6,000 portable buildings that the districts leased from the state and about 44,000 other relocatables on public K-12 school campuses. In the case of the leased portables, the state has certain building specifications (i.e., heating capacity, air flow capacity, and other basic/standard criteria) but the buildings are only inspected 
by the state if there is a problem or if they are being returned to the state. Although there is considerable evidence that some schools have air quality problems, the extent and severity of air quality and ventilation problems in California schools in general are not known.

Poor indoor air quality is a known cause of a number of significant adverse health effects. Asthma, which affects approximately $5 \%$ of the population (ALA, 1996) ${ }^{\text {a. }}$, can be triggered by airborne allergenic matter from house dusts mites which commonly grow in carpets and by irritant vapors and gases, such as formaldehyde and ozone, which are commonly found in indoor environments. In 1985, asthma was responsible for approximately 1.8 -million emergency room visits for the U.S. as a whole. Health care costs for asthma in the U.S. were estimated to be $\$ 6.2$ billion in 1990 .

The indoor environment affects the rates of transmission of important infectious diseases such as influenza (approximately 20 million cases occur annually in the U.S.), tuberculosis, and common colds. In a study by the U.S. army, occupants of barracks with low ventilation rates and extensive air recirculation had a $50 \%$ higher incidence of respiratory disease with fever than occupants of older, betterventilated barracks (Brundage, et al., 1988). Reduction of even 10\% of respiratory disease transmission in schools would be beneficial to students, staff and parents.

Sick building syndrome (SBS) is characterized by a set of symptoms that occur in association with occupancy of a building and disappear when occupants leave the building. The symptoms include eye, nose or throat irritation, dry or irritated skin, headache, fatigue, and difficulty breathing. It has been estimated that SBS may affect $20 \%$ of new office buildings and a smaller but significant fraction of older buildings. The causes are not known but are suspected to be multifactorial. Both the volatile organic compounds and bioaerosols are suspected as etiologic agents in SBS. Although most SBS has been reported for office buildings, there have been some reports of schools with SBS symptoms in occupants.

Poor indoor air quality may affect the learning performance of students in several ways. Absenteeism due to illnesses (e.g., asthma, respiratory diseases) clearly results in lost opportunities to learn. Such illness in students is also likely to reduce their learning abilities even when they are in school. At a less severe level, SBS symptoms may also result in learning deficits in students.

There is also evidence that school rooms that are too hot or too cold can also significantly affect student performance, although the relationships are complex and depend upon the type of task (e.g., Pepler and Warner, 1968; Wyon, et al., 1979; Fisk and Rosenfeld, 1997). Edwards (1991) has reported evidence that Washington, DC students standardized achievement scores increased as school conditions improved after controlling for other variables such as socioeconomic status.

\footnotetext{
a. Potentially there are more than 275,000 California students and 10,000 California teachers with asthma. Nationally, the American Lung Association (ALA, 1996) estimates that as many as 5.3 million children suffer from asthma. ALA also notes that asthma is the number one cause of school absenteeism due to chronic health problems, and the leading chronic illness among elementary school children. ALA believes that asthma causes children to experience 16 million days of restricted activity annually in the U.S., including days spent in bed and days misses from school.
} 


\subsection{Objectives}

In view of the potential adverse health effects from poor indoor air quality in schools, a critical review was undertaken of existing published literature and reports on indoor air quality (IAQ), ventilation, and IAQ- and building-related health problems in schools. Information on California schools, in particular, was sought. The objectives of this review were to:

1. Identify the most commonly reported building-related health symptoms involving schools;

2. Assemble, evaluate, and summarize existing measurement data on key indoor air pollutants most likely to be related to these symptoms, e.g., $\mathrm{CO}_{2}$, volatile organic compounds, bioaerosols;

3. Assemble and summarize existing measurements of ventilation rates in schools;

4. Summarize information on causes of indoor air quality problems and symptoms in schools.

Since indoor air quality complaints are almost always related to acute or more short-term health effects and symptoms, emphasis was placed on publications and reports of these types of health effects rather than chronic (or long-term) health effects such as cancer. 


\subsection{METHODS}

Publications in the peer-reviewed and archival scientific literature, National Institute for Occupational Safety and Health (NIOSH) and other government reports, and reports of investigations of California schools were identified, assembled, and reviewed and a bibliography was prepared.

\section{I Search of the Published Scientific Literature}

The scientific literature published in journals and conference proceedings was searched through a number of electronic databases using the following keywords: school, air quality, air pollution, ventilation, carbon dioxide, volatile organic compounds, carbon monoxide, formaldehyde, bioaerosols, molds, dust mites, and mildew. The following databases were searched:

- Academic Index (1980 through 1995);

- Airbase from the Air Infiltration and Ventilation Center (through August 15, 1995);

- Applied Science and Technology Index (1983 through 1995);

- Chemical Abstracts (1975 through January 1996);

- Concentration of Indoor Pollutants (CIP) Database developed by Lawrence Berkeley National Laboratory;

- Current Contents (1989 through January 1996);

- Education Resource Information Center (1960 through 1995);

- General Science Index (May 1984 through 1995);

- Inside Information (through 1995);

- Inspec (1987 through 1995);

- Medline (1990 through January 1996); and

- Toxline (1981 through January 1996).

In addition, a number of journals were manually searched including: American Society of Heating, Refrigerating, and Air-Conditioning Engineers (ASHRAE) IAQ Conference Proceedings; ASHRAE Journal; ASHRAE Transactions; and U.S. Environmental Protection Agency (EPA) Radon Proceedings.

References identified through these searches were obtained and reviewed. Citations of scientific indoor air quality and ventilation investigations and of acute symptoms related to indoor air quality and building characteristics in schools in the U.S., Canada and Europe were retained in the bibliography. References on radon and asbestos in schools were usually omitted because the health effects of these agents are chronic and the focus of this literature survey was on acute symptoms and agents related to such symptoms. However, several studies of radon in schools were retained because they reported measurements of ventilation and $\mathrm{CO}_{2}$ in schools. Papers providing guidance on improving indoor air quality and ventilation were omitted.

There were two additional data sets in the peer-reviewed scientific literature that were examined sn this search:

- The Lawrence Berkeley National Laboratory's (LBNL) mid-1980s assessment of ventilation rates and particle concentrations in 38 Oregon and Washington buildings including six schools (non- 
complaint buildings selected to be "typical" of those in this region but they are not representative of non-residential buildings in the region (Turk, et al., 1987a,b).

- The EPA's School Evaluation Program (SEP) data collected in the early 1990s from 12 schools in Florida, Kansas, New Mexico, and Washington with elevated indoor radon (probably reflect noncomplaint buildings but they are not necessarily representative of any group of school buildings).

There is an additional report that summarizes some of the peer-reviewed school indoor air quality literature. U.S. EPA contractor ICF Kaiser (1995) conducted a keyword search and summarized a portion of the literature including the 12 EPA-SEPs cited above, 10 of about 88 NIOSH K-12 school Health Hazard Evaluation Reports (including two excluded from this review as non-representative of K-12 school buildings: a University medical center; and a central kitchen facility).

\subsection{Search for Other Literature}

In early March 1996, letters requesting information and copies of any unpublished reports on indoor air quality problems in California schools were sent to 52 Directors of Environmental Health, 62 California (County) Health Officers and to 62 counties in California Air Pollution/Air Quality Districts. Table 4.1 summarizes the responses that were received and the number of reports obtained.

Table 4. 1 California School Indoor Air Quality Reports, Number of Requests, Responses, and Reports Received

\begin{tabular}{|c|c|c|c|}
\hline Group & Letters Sent & Responses & Reports Received \\
\hline Directors of Environmental Health & 52 & 18 & $42^{\mathrm{a}}$. \\
\hline County Health Officers & 62 & 9 & 5 \\
\hline Air Pollution/ Air Quality & 62 & $13^{\mathrm{b}}$ & 0 \\
\hline \multicolumn{4}{|l|}{ Districts } \\
\hline Other Sources ${ }^{\mathrm{c}}$. & $1^{\mathrm{d} .}$ & 1 & 23 \\
\hline Total: & 177 & 41 & 70 \\
\hline
\end{tabular}

The overall response was about $35 \%$ if the 35 counties covered by responses from air quality districts are tabulated under air pollution/air quality districts group. The total number of reports received on IAQ investigations of schools in California was 64. Fifty-six of these reports originated from two southern California county health departments and the remainder were produced by environmental consultants. Seven of the health department reports involved buildings not containing classrooms (e.g., dining hall, administrative office, youth services organization group room) and thus, were excluded from this review.

Also, the ICF Kaiser (1995) assessment of consultant and news media school indoor air quality investigative reports was obtained and reviewed as were state school surveys including those in Florida (Florida Indoor Air Quality Advisory Committee, 1995) and New York (Regents Advisory Committee, 1994a and 1994b). 


\subsection{BUILDING-RELATED SYMPTOMS AND COMPLAINTS REPORTED FOR SCHOOLS IN THE UNITED STATES, CANADA AND EUROPE}

\section{I National Institute for Occupational Safety and Health's (NIOSH) Health Hazard Evaluations (HHERs)}

NIOSH has conducted thousands of field investigations of possible health hazards in the workplace under authorization of the Occupational Safety and Health Act of 1970 . The investigations have been conducted following a written request from an employer or authorized representative of employees to determine whether any substance normally found in the workplace has potential toxic effects. NIOSH also has provided technical assistance to federal, state, and local health agencies and others to control occupational health hazards. The field investigations are summarized in Health Hazard Evaluation Reports (HHER). About 98 HHERs address investigations about indoor air quality in educational facilities. ${ }^{2}$ The HHERs range from very brief reports in the form of correspondence, especially in earlier years, to extensive documentation of investigations.

The HHERs included the following: 1) a summary of the original complaint or problem and description of the building; 2) a description of medical evaluation methods often including interviews conducted by a medical officer and, after 1992, data obtained from NIOSH's Indoor Air Quality and Work Environment Symptoms Survey; 3) description of environmental evaluation methods for the overall building, the complaint area, and the HVAC system as well as a description of sampling methods concerning occupant comfort (temperature, relative humidity, carbon dioxide) and other indoor air pollutants (e.g., carbon monoxide, formaldehyde, hydrogen sulfide, VOCs); 4) a description of evaluation criteria including limitations of existing standards; 5) a discussion of medical and environmental results or findings; and 6) conclusions and recommendations to improve indoor environmental quality.

The 77 NIOSH HHERs reviewed in this report were conducted from 1981 to 1994 and provide a national perspective on indoor air quality complaints and issues across 31 states. However, half of these HHERs were from three states: Pennsylvania, Ohio, and West Virginia, and none was conducted in California. The relatively standardized structure and methodology of the NIOSH HHERs have been used as a framework to assess and compare California school investigative reports and the school indoor air quality papers found in the peer-reviewed literature.

NIOSH school HHERs are relatively unique in as much as they report first, what building-related health symptoms or workplace complaints were reported prior to the field investigation and second, what health effects and workplace conditions were found as a result of the investigation. These two perspectives are summarized in the following two sections. However, it must be emphasized that these investigations did not include any follow-ups to determine if the recommended measures were implemented and whether they significantly reduced the reported symptoms; thus cause and effect were not rigorously determined.

2 A total of 88 NIOSH HHER involving educational facilities were identified and obtained. Ten additional NIOSH school HHERs were identified through the literature and data base searches but were not obtained in time to be included in this report. The 88 NIOSH school HHERs that were obtained included 11 that involved buildings that did not have kindergarten though twelfth grade (K-12) classrooms (e.g., central kitchen facility, administrative center, University hospital) and thus, these 11 HHERs were not included in this review. 


\subsubsection{Types of Health and Environmental Complaints Prompting Evaluation}

Of the 77 analyzed NIOSH school HHERs, 53 listed specific occupant health symptoms and/or environmental complaints that were identified in the initial request for the evaluation or were identified

prior to the field medical and environmental evaluation. The remaining HHERs, were too general to classify or were pollutant specific.

The distribution of complaints for these 53 HHERs is summarized in Figure 5.1 and Appendix A. Almost all of the complaints that prompted school HHERs were health related, although a small portion cited environmental conditions, especially odors. The health complaints were often the same type that are classified as "sick building syndrome" (SBS) as defined by the World Health Organization (WHO, 1979) (e.g., eye, nose or throat irritation, headaches, fatigue, dry or itchy skin, difficulty breathing or chest tightness) while others were not (e.g., pain or stiffness in the back, shoulders or neck). SBS symptoms are a spectrum of nonspecific complaints that occur during building occupancy and which are absent or less severe when the individuals are not in the building. In some cases, these symptoms can be associated with specific environmental causes that are building-related. However, SBS is distinguished from problems of "building related illness" (BRI). BRI refers to situations where some environmental agent can be measured at or near a known health effect threshold and can be related to the reported symptoms. For example, carbon monoxide poisoning caused by faulty combustion devices or vehicles, Legionnaires' Disease, and Pontiac fever caused by Legionella bacteria are building related illnesses.

\subsubsection{Medical Evaluation Findings and Occupant Rated Environmental Conditions}

About one-third of the NIOSH school HHERs (26 of 77) reported using some means to assess and report occupant health and environmental conditions. These conditions are summarized in Appendix B. Most of these symptoms are "nonspecific," meaning that they do not indicate a specific disease. The majority of these health assessments involved written questionnaires distributed to affected populations, usually teachers and other staff. The size of the populations surveyed in the school HHERs ranged from eight in Crandall and Wilcox (1992) to 5799 in Gorman and Singal (1984). The response rates range from 26 percent in McCammon (1990) to 100 percent (92 of 92) in Burr, et al. (1993). Some of the earlier NIOSH reports involved clinical examinations rather than questionnaires.

Since 1991, NIOSH has used a self-administered, confidential written questionnaire to collect data from occupants concerning health symptoms experienced at work during the last four weeks and for any symptoms experienced, whether the symptom changed when away from work as well as whether the symptom was experienced on the day the survey was completed. The questionnaire also asked about environmental conditions experienced during last four weeks at work as well as on the day the survey was completed. The questionnaire was modeled after several other questionnaires that had been used in previous building investigations. This standardized instrument (Center for Disease Control, 1991) was used in 14 of the most recent school HHERs involving 552 respondents. The results are reported in Figure 5.2 which summarizes health symptoms experienced over the previous four weeks that improve when away from work. For example, 17 percent (91 of 522) of the respondents indicated they had a stuffy or runny nose or sinus congestion during the last four weeks while at work and that the symptoms got better when they were away from work (e.g., over holidays and weekends). 
Figure 5.1 Types of Health and Environmental Complaints Cited in Request for Evauation, 53 NIOSH School Health Hazard Evaluation Reports, 1981 - 1994

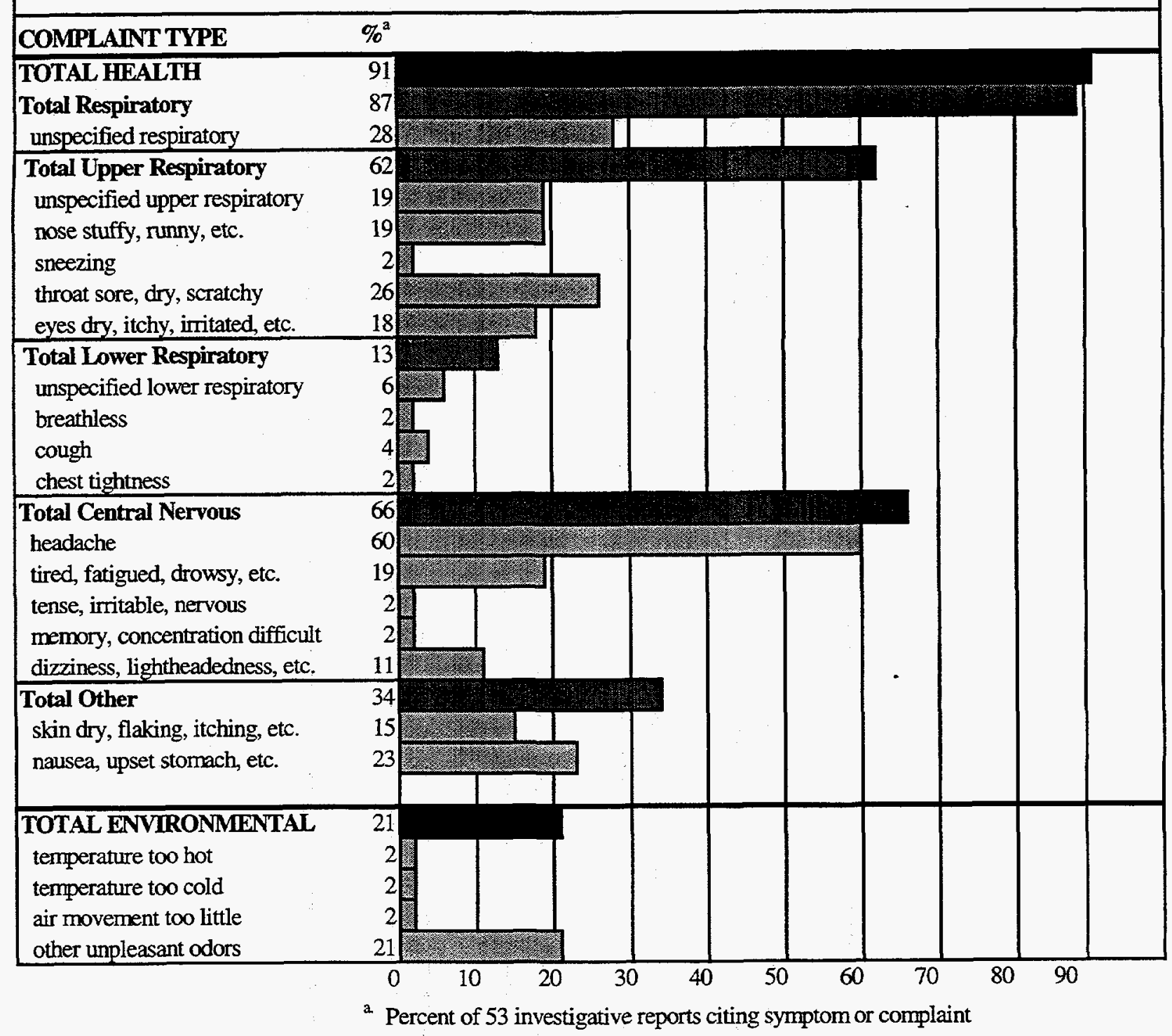

Figure 5.1 Types of Health and Environmental Complaints Cited in Request for Evaluation, 53 NIOSH School Health Hazard Evaluation Reports, 1981 - 1994 
Figure 5.2 Health Symptoms Experienced at Work and Environmental Conditions During Four Weeks

Before Survey and the Percentage of all Respondents Whose Symptoms Improve Away From Work, 522 Respondents in 14 NIOSH School Health Hazard Evaluation Reports, 1993 - 1994

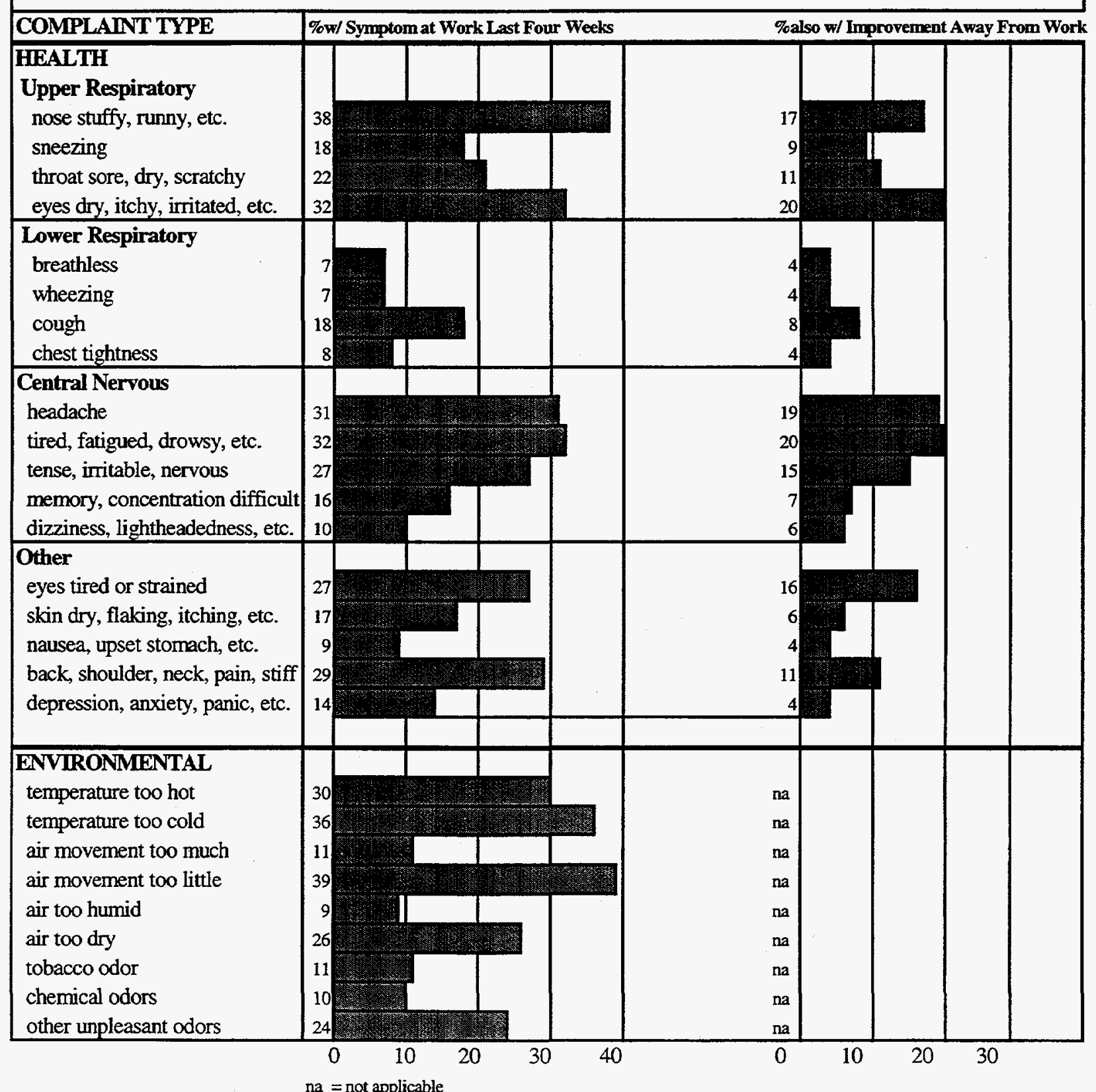

Figure 5.2. Health Symptom Prevalences and Perceived Environmental Deficiencies for 522 Respondents in 14 NIOSH School Health Hazard Evaluation Reports, 1993-1994. Health symptom prevalences are the percent of respondents who report that they have experienced the symptom 1 to 3 days per week in the last 4 weeks, or every or almost every work day and the symptom gets better away from work. 
Occupant-reported health symptoms found as a result of these $14 \mathrm{NIOSH}$ evaluations were similar to the health complaints that prompted the HHERs, e.g., upper respiratory symptoms were more common than lower respiratory symptoms and central nervous system symptoms were relatively common in both cases. The symptoms that improved when away from work ranged from a high of 20 percent for dry, itching or irritated eyes and for unusual tiredness or fatigue to a low of four percent for feeling depressed, nausea or upset stomach, chest tightness, wheezing, and breathless. Although the prevalences of lower respiratory symptoms (breathless, wheezing, cough, chest tightness) that improved when away from work were low (only 4\% to $8 \%$ ), these symptoms may be more serious since they may be indicative of asthma symptoms induced by environmental agents and conditions in the schools.

Other health symptoms present at work during the four weeks before the survey (regardless of improvement away from work) and those present on the day of the survey are included in Appendix B. There was very little difference between the pattern of responses between the last four weeks and the day of the survey.

In general, the most commonly reported symptoms in NIOSH's school HHERs that improved away from work were eye, nose, and throat irritation, headaches and unusual tiredness or fatigue. These symptoms appear remarkably similar to those associated with "Sick Building Syndrome" (SBS) in office buildings (Hodgson, 1988). However, the prevalence of the symptoms in the NIOSH complaint schools appears to be consistently less than that in NIOSH complaint office buildings. Malkin, et al. (1996) reported on symptom prevalence (one to three days per week, or every or almost every day, over the last four weeks and get better away from work) among 2435 workers in 80 complaint office buildings and the prevalence was almost always slightly higher for each symptom in the offices compared with 522 staff in the 14 NIOSH schools, e.g.:

- headache at $19 \%$ in schools and $25 \%$ in offices;

- nose stuffy, runny or congested at $17 \%$ in schools and $21 \%$ in offices;

- eyes tired or strained at $16 \%$ in schools and $32 \%$ in offices; whereas

- wheezing was $4 \%$ in both cases.

Malkin, et al. (1996) also compared the HHERs office worker health symptom data for complaint buildings with that of Nelson, et al. (1995) data for 646 workers in four non-complaint offices in Washington State and found virtually no difference. Malkin, et al. concluded, "This agreement for most symptoms suggests that there may be a surprising high base-line of prevalence rates for many symptoms in office buildings throughout the country, and that the designation of a building as a problem may be related to factors other than symptom prevalence."

In the California Healthy Building Study (Fisk, et al., 1993; Mendell, et al., 1995) investigation of 13 office buildings ( 880 respondents), of which only one building had a history of occupant complaints, a similarly high baseline of work-related health symptoms was also found. Overall, more than $40 \%$ of the workers reported that work-related eye, nose, and throat irritation occurred often or always, although symptom prevalences varied considerably among the buildings.

Occupant ratings of environmental comfort conditions at work during the four weeks prior to the survey was completed are also summarized in Figure 5.2 for the 14 HHERs. Temperatures that were too hot or too cold were reported by $30 \%$ or more of the respondents. Almost $40 \%$ reported too little air 
movement. This pattern was similar to that reported by Malkin, et al. (1996) among 2435 workers in 80 complaint office buildings, shown in Table 5.1. High percentages of the respondents in both the school and office HHERs reported too little air movements, $39 \%$ and $50 \%$, respectively.

Table 5.1 Comparison of Occupant Ratings of Environmental Comfort Conditions in HHERS for Schools and Office Buildings

\begin{tabular}{llc}
\hline Comfort Problem & $\begin{array}{c}\text { Percent of School Respondents } \\
\text { Reporting }\end{array}$ & $\begin{array}{c}\text { Percent of Office Building } \\
\text { Respondents Reporting }\end{array}$ \\
\hline - temperature was too hot & 30 & 35 \\
- temperature was too cold & 36 & 32 \\
- too little air movement & 39 & 50 \\
- air too dry & 26 & 35 \\
- air too humid & 9 & 12 \\
- tobacco smoke odors & 11 & 15 \\
\hline
\end{tabular}

Almost all of the NIOSH school assessments excluded students. Gorman and Singal (1984), however, investigated and compared medical symptoms for both faculty and students (via students' parents' responses) from a local New York health department survey. As reflected in Table 5.2, the general distribution of medical symptoms in three complaint schools was similar between 376 (response rate of $77 \%$ of 486 ) faculty respondents and 2744 (response rate of $62 \%$ of 4411 ) students.

Gorman and Singal (1984), Cantor and Lee (1987), and Salisbury and Scharf (1993) were unique among NIOSH school HHER investigators in the use of control populations in similar non-complaint schools or non-complaint areas in the same school. These investigators reported an overall higher frequency of medical symptoms in the complaint school populations relative to the controls. For example, in Gorman and Singal, $36 \%$ of the faculty and $39 \%$ of the students had dry or itchy eyes compared to $12 \%$ of the faculty and students in a control school (Table 5.2).

Table 5.2 Comparison of Faculty and Student Health Symptoms Experienced in Three New York Complaint Schools and a Control School in Percent ${ }^{2 .}$

\begin{tabular}{lcccc}
\hline Symptom & \multicolumn{2}{c}{ Complaint Schools } & \multicolumn{2}{c}{ Control School } \\
& Faculty & Students & Faculty & Students $^{\text {b. }}$ \\
\hline Stuffy or runny nose or congestion & $22 \%$ & $26 \%^{\text {b. }}$ & $14 \%$ & $27 \%$ \\
Sore or dry throats & 36 & 38 & 18 & 26 \\
Dry or itchy eyes & 36 & 39 & 12 & 12 \\
Coughs & 24 & 31 & 10 & 26 \\
Headaches & 37 & 51 & 24 & 30 \\
\hline $\begin{array}{l}\text { a percent of subjects reporting they temporally experienced the symptom at school, from Gorman and Singal, } 1984 . \\
\text { reported by parents }\end{array}$
\end{tabular}

Cantor and Lee (1987) also reported a large difference in staff health symptoms experienced at work but not at home for a complaint school compared to a control school. The largest differences in symptom prevalences between complaint and control populations were reported by Salisbury and Scharf 
(1993) for an Alabama high school. These results are shown in Table 5.3. However, the total number of occupants surveyed in both complaint and non-complaint areas was small, only 67.

Most NIOSH school reports did not segregate occupant reported health symptoms by gender even though there is evidence that the frequencies vary by gender. For example, Malkin, et al. (1996) reported the prevalence of health symptoms that were reported (one to three days per week, or every or almost every day, over the last four weeks and get better away from work) among 814 male and 1607 female workers in 80 complaint office buildings studied in NIOSH HHERS. Symptom prevalence among women were often nearly double that of men.

A number of the HHERS reported that building-related health complaints or symptoms had existed for years, had been subject to teacher union demands, and had been subject to prior investigations that did not identify any specific health hazards (cf. Anderson and Daniels, 1993; Blade, 1992).

Table 5.3 Health Symptoms Over Four Weeks That Got Better When Away From Work of School Staff in Complaint and Non-Complaint Areas in Percent

\begin{tabular}{lcc}
\hline Symptom & Complaint Area Staff & Non-Complaint Area Staff \\
\hline Stuffy or runny nose or sinus congestion & $24 \%$ & $0 \%$ \\
Sneezing & 6 & 0 \\
Sore or dry throat & 13 & 0 \\
Dry, itchy or irritated eyes & 25 & 0 \\
Shortness of breath & 6 & 0 \\
Wheezing & \multicolumn{1}{c}{. } & 0 \\
Cough & 6 & 0 \\
Chest tightness & 6 & 0 \\
Headache & 31 & 4 \\
Unusual tiredness, fatigue or drowsiness & 31 & 4 \\
& & \\
Tension, irritability, or nervousness & 19 & 4 \\
Difficulty remembering things or concentrating & 13 & 4 \\
Dizziness or lightheadedness & 13 & 0 \\
Tired or strained eyes & 6 & 4 \\
Dry or itchy skin & 13 & 0 \\
& & \\
Nausea or upset stomach & 0 & 0 \\
Pain or stiffness in back, shoulders or neck & 13 & 0 \\
Feeling depressed & 6 & 0 \\
\hline
\end{tabular}


In summary, the NIOSH school HHERs occupant health symptoms and environmental conditions assessments indicated:

1. a very substantial percentage of respondents with SBS-type symptoms, similar to those reported in office "sick buildings";

2. health complaint questionnaire responses were similar to the initial complaints that prompted the evaluations;

3. in the few HHERs in which complaint and noncomplaint buildings or areas were compared, higher rates of health symptoms were found in the complaint buildings or areas.

\subsection{Health Symptoms and Environmental Conditions in Schools as Reported in the Published Scientific Literature}

The published literature on health symptoms and environmental problems in schools differ from the HHERs in three major respects. First, the NIOSH investigations were always initiated in response to complaints and there was an expectation that NIOSH would be able to mitigate the cause of the complaints, although follow-up studies were not conducted to confirm this. In contrast, the purposes of the studies reported in the peer-reviewed scientific literature vary widely, e.g., to better understand the general the causes of commonly reported symptoms, such as SBS, to characterize indoor concentrations of air pollutants, etc.

Secondly, the HHERs generally utilize a fairly standardized protocol, although this has evolved over the years. The studies in the published literature utilize a variety of study protocols, which depend upon the particular study. Thirdly, the HHERs report information on the health symptoms of the school occupants. Studies reported in the published scientific literature may or may not include information on the symptoms or complaints of the building(s) occupants, depending upon their specific purposes. The health or symptom data collected in various studies are also collected by a variety of methods. Thus, it is not possible to do any rigorous quantitative comparisons of symptom reporting for studies published in the archival literature with the HHERs. Nonetheless, the symptom complaints for school studies reported in the published scientific literature are very similar qualitatively to those in the NIOSH HHERs.

For the purposes of this review, the most important studies in the published scientific literature are those designed specifically to investigate relationships between occupant symptoms and potential causes of SBS symptoms as well as asthma. Among these studies are several investigations of the relationships between symptom prevalences and $\mathrm{CO}_{2}$ concentrations and/or ventilation rates in schools. The results of these studies have been mixed, as might be expected since ventilation rate and $\mathrm{CO}_{2}$ concentrations are only surrogates for the actual agents which might be causing the symptoms.

Potting, et al. (1987) reported on an epidemiological study in 3 complaint and 4 non-complaint schools (14 classrooms total) in the Netherlands to assess relationships between SBS symptom complaints of children and $\mathrm{CO}_{2}$ levels and indoor climate. Concentrations of $\mathrm{CO}_{2}$ exceeded the guidelines $(1200 \mathrm{ppm})$ for $27 \%$ to $97 \%$ of the time when the classrooms were occupied. These investigators found no statistically significant difference in the prevalences of health complaints with $\mathrm{CO}_{2}$ concentrations or between the complaint and non-complaint schools. The complaint of "bad odor of the air" was associated with high $\mathrm{CO}_{2}$ levels.

More recently, Myrvold, et al. (1996) reported on pre- and post-renovation measurements made in 22 classrooms in 5 schools in Norway which were renovated to provide good indoor air quality. Preand post-renovation measurements were made of $\mathrm{CO}_{2}$ as a ventilation rate indicator. Health symptom questionnaires and three performance tests were administered to 550 students. These investigators found 
a statistically significant partial correlation (one way ANOVA, $p<0.001$ ) between Health Index 1 (which reflected symptoms of headaches, dizziness, heavy headed, tiredness, difficulties concentrating, and unpleasant odor) and high $\mathrm{CO}_{2}$ concentrations (1500-4000 ppm) compared to concentrations below $1500 \mathrm{ppm}$. Health symptoms characterized as "irritations of the upper airways" (Health Index 2) were also higher at higher $\mathrm{CO}_{2}$ concentrations, although the statistical significance was lower $(\mathrm{p}=0.024)$. Reduced performance on the Swedish Performance Evaluation System test was also observed at higher concentrations of $\mathrm{CO}_{2}$. Although measurements of VOCs were made, they were not reported in this preliminary report of the ongoing study.

In a study involving 1410 employees in 38 Swedish schools, Smedje, et al. (1996) found no statistically significant relations between asthma and $\mathrm{CO}_{2}$ concentrations, air exchange rates, visible damp, amount of open shelves or fabrics in the classroom, room temperature, relative humidity, respirable dust, viable or total bacteria, total VOC, cat or dog allergen or endotoxin in settled dust. Asthma was, however, more common among subjects working in schools with higher concentrations of total molds in the air, even after controlling for other factors, i.e., allergies, stressful work situation and recent repainting of homes. In another report of this study population, Smedje, et al. (1997) reported finding no statistically significant relations between subjective air quality and $\mathrm{CO}_{2}$ concentrations or air exchange rates. Subjective air quality was, however, significantly related to measurements of total molds, total bacteria, total VOC, respirable (airborne) and settled dust.

In a study of 579 asthmatic Danish children, Hansen, et al. (1987) reported an increased severity of asthma in schools with carpet compared to the children in schools with no carpet. This association was especially strong for the children who had no carpet in their rooms at home and had no pets.

Norback and Torgen (1987) compared questionnaire responses from (94\% response rate) 59 staff members in two Swedish schools with wall to wall carpeting and 133 staff members in four schools without carpeting. Questionnaires were administered (N=141) in 1982 and then again in 1986 after carpeting was removed. Table 5.4 summarizes the results of the questionnaire for 1982 . There was a significantly higher frequency of health complaints in carpeted classrooms $(p \leq 0.03)$. Four years later, 37 of the 59 staff in the two carpeted schools with the carpet removed and 81 of the 133 staff in the four schools without carpeting were re-surveyed and it was found that some of the health complaints remained significantly higher among those that previously had carpeting $(p \leq 0.02)$. This suggests that some agent(s) associated with carpet, such as allergenic dusts or volatile organic compound emissions, are the cause of SBS symptoms, at least in some buildings.

Table 5.4 Symptom frequencies among school personnel with wall-to-wall carpet in their workrooms in comparison with school personnel with hardwood floor coverings, 1982 (Percent in Group reporting the symptom) (Reported by Norback and Torgen, 1987).

\begin{tabular}{lcc}
\hline Type of symptom & $\begin{array}{c}\text { Wall-to-wall carpeting } \\
\text { group }\end{array}$ & $\begin{array}{c}\text { Hard floor covering } \\
\text { group }\end{array}$ \\
\hline Eye irritation & $31 \%^{*}$ & $14 \%$ \\
Blocked-up nose & $22 \%$ & $19 \%$ \\
Dryness in the throat & $50 \%^{*}$ & $18 \%$ \\
Smarting of the throat & $27 \%^{*}$ & $9 \%$ \\
Irritative cough & $24 \%^{*}$ & $8 \%$ \\
Headache & $37 \%^{*}$ & $20 \%$ \\
Sensation of getting a cold & $47 \%^{*}$ & $22 \%$ \\
Nausea & $3 \%$ & $5 \%$ \\
Eczema & $14 \%$ & $15 \%$ \\
\hline
\end{tabular}

* Statistically significant differences $(p \leq 0.001)$ between those with carpeting and those with hard floor coverings in 1982 
In a later report on the longitudinal study on the effects of removal of wall-to-wall carpeting, Norback, et al., (1990) reported on relationships between prevalences of SBS symptoms among personnel in 6 primary schools in Sweden, indoor exposures and personal factors. Chronic SBS symptoms, that is symptoms reported in both 1992 and in 1996, were related to VOC concentrations, previous occupancy in a classroom with wall-to-wall carpeting, hyperactivity and psychosocial factors. The incidence of new_SBS symptoms (symptoms reported in 1986 but not in 1982) was related to the concentration of respirable dust, current smoking and the psychosocial climate.

Kostinen, et al. (1997) compared respiratory symptoms and infections in children (3-7 years old) in two day-care centers with visible mold growth on interior walls (exposed children) to those in two reference day care centers (non-exposed children). The health status of the 229 children was recorded by parents in symptom diary questionnaires during two study periods. During the first period, the children in the two day-care centers with mold problems (exposed) had a significantly increased risk of sore throat, purulent and non-purulent nasal discharge, nasal congestion, hoarseness and common cold than those in the two reference day care centers (non-exposed). During the second follow-up period, a significantly increased risk of purulent nasal discharge, nasal congestion, hoarseness and cough was observed for the exposed populations compared to the unexposed. Overall morbidity for respiratory symptoms and common cold were higher in the daycare centers with the mold than in the two reference day car centers. This study was consistent with the results of an earlier comparative study of two day care centers, one with and one without mold problems (Koskinen, et al., 1995).

\subsection{Types of Health and Environmental Complaints Prompting California School Investigations}

All of the California schools investigations were conducted in response to some complaint or request for an investigation. Thirty-five (half) of the indoor air quality investigative reports of California schools listed occupant health symptoms and/or environmental complaints, including odors, that were identified in the request for the evaluation or were identified prior to the field environmental evaluation. The remaining California school reports were too general to classify, were pollutant specific, or the reports simply did not report any symptom or complaint. The distribution of complaints is summarized in Figure 5.3. Overall, the health symptoms reported in the California school investigations bear a resemblance to the SBS character of the NIOSH school and office HHERs. Most common occupant health symptoms in the California schools were respiratory problems, especially upper respiratory problems and central nervous system problems although the frequency of central nervous system symptoms reported was lower in the California reports compared to the HHERs.

In addition to health symptoms, 63 percent of the 35 California school reports listed complaints about environmental conditions in the workplace. This rate of environmental complaints was three times greater than the rate found in the NIOSH school HHERs (21\%). The two major areas of differences in environmental complaints between California and NIOSH investigations are the unpleasant odors (54\% versus $21 \%$ in the HHERs) and too little air movement (17\% versus $2 \%$ ). The reasons for these differences are unknown but likely to be related to: 1) the limited number and representativeness of these reports; and 2) climatic differences in design, construction, operation, or maintenance of schools in California compared to other states. In addition, local health departments were the major source of the California reports and they may respond to a wider range of indoor air quality concerns, such as odors, than NIOSH. 
In contrast to the recent NIOSH school HHERs, none of the reports of the California school indoor air quality investigations indicated that there were standardized medical evaluations using, for example, written questionnaires. Thus, the frequency of occupant health symptoms and environmental complaints cannot be assessed. It would be helpful to have occupant workplace health symptom and workplace environmental assessments from California schools. Without such data, understanding about indoor air quality in the State's schools is incomplete. Once again, the bulk of the California reports were from two local health departments.

Figure 5.3 Pre - Investigative Health and Environmental Complaints,

35 California School Indoor Air Quality Investigations, 1988 - 1996, and 53 NIOSH School Health Hazard Evaluation Reports, 1981 - 1994

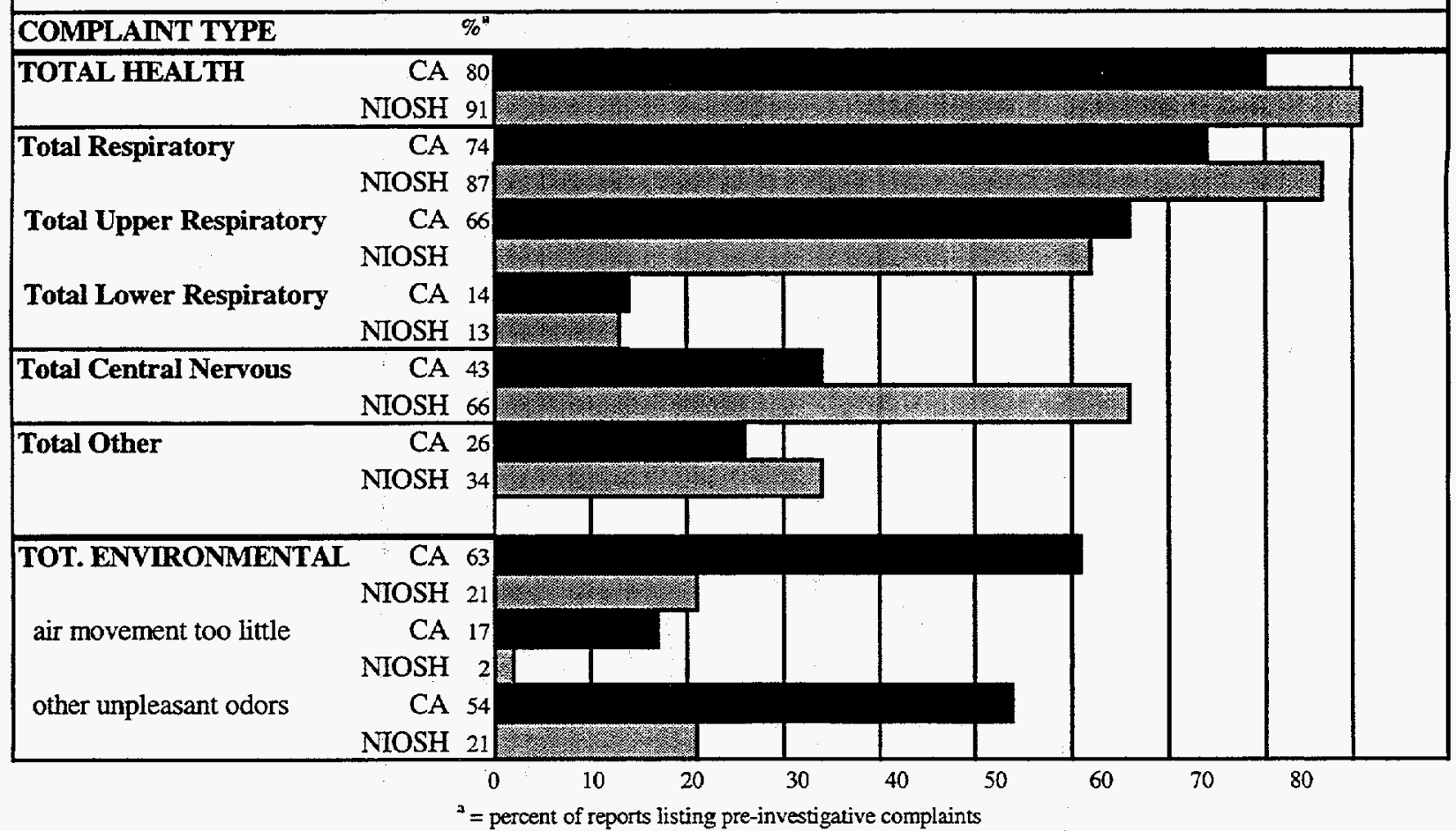

Figure 5.3 Comparison of Pre-Investigative Health and Environmental Complaints for 35 California School Indoor Air Quality Investigations, 1988-1996, and 53 NIOSH School HHERs, 19811994. 


\subsection{Summary}

In general, the types of symptoms reported in the NIOSH HHERs and the California schools investigations are very similar those defined as SBS symptoms, although this may be due, at least in part, to the type of health symptom questionnaires used in the HHERs. Some of the symptoms, e.g., wheezing, probably reflect underlying chronic diseases such as asthma. In the few HHERs in which complaint and noncomplaint buildings or areas were compared, higher rates of health symptoms were found in the complaint buildings or areas. The symptom complaints for school studies reported in the published scientific literature are also very similar qualitatively to those in the HHERs.

Some of the studies reported in the published scientific literature were conducted to elucidate the causes of SBS and other health effects, such as asthma, in problem schools and typically included control populations or pre- and post-mitigation measurements of symptoms. These studies indicate that exposures to molds and to allergens found in deposited dusts in schools are related to asthma, SBS and other respiratory symptoms. Other personal and psychosocial factors also contribute to symptom prevalences and must be accounted for in these studies. The effects of exposures to many other indoor air pollutants, such as VOCs, aldehydes, endotoxins in dust, etc., have been investigated to only a very limited extent, although there are reasons to suspect that these agents may also contribute in varying degrees to health symptom prevalences in schools.

In many of these epidemiological studies, actual exposures to molds, allergens, VOCs, etc., were not measured for the individuals, or were measured in indoor air for only very short time periods. In some studies, exposures were not measured at all, e.g., the presence of mold in a building was used as an indicator of exposure. Thus, the exposure- and dose-response relationships for SBS and other health symptoms are not well characterized and it is difficult to set scientifically-based standards for health protection. Because of the lack of a quantitative understanding of exposure and response, it is not possible to estimate how much of a reduction in health effects and symptoms can be achieved for a given reduction in exposure to any given agent. Thus, the effectiveness (and cost-effectiveness) of various mitigation measures and exposure reduction measures remains highly uncertain. 


\subsection{Measurements of Carbon Dioxide and Ventilation Rates in Schools}

\subsection{Carbon Dioxide Measurements}

The most commonly measured pollutant in the NIOSH HHERs, the studies reviewed by ICF Kaiser, and the reports on indoor air quality in California schools is $\mathrm{CO}_{2}$. The primary sources of carbon dioxide in buildings are outdoor air and the metabolic activity of building occupants. $\mathrm{CO}_{2}$ is often used as a surrogate for other occupant-generated pollutants, some of which are odorous, and as an indicator of the rate of outside air supply per occupant. The concentration of $\mathrm{CO}_{2}$ in outdoor air is about $350 \mathrm{ppm}$. Indoor concentrations above about $1000 \mathrm{ppm} \mathrm{CO}$ are generally regarded as unacceptable with respect to body odors. Concentrations of $\mathrm{CO}_{2}$ below $1000 \mathrm{ppm}$, however, do not always guarantee that the ventilation rate is adequate for removal of air pollutants which originate from other indoor sources and adversely affect human health and comfort.

The Threshold Limit Value (TLV) recommend by the American Conference of Govermmental Industrial Hygienists (ACGIH) (1994) for an 8-hour working day in an industrial setting is 5,000 ppm. This TLV was set to provide a good margin of safety from asphyxiation and undue metabolic stress. These health effects have been observed in human subjects at levels of $15,000 \mathrm{ppm}$ and higher. Prolonged exposures to $\mathrm{CO}_{2}$ at $5,000 \mathrm{ppm}$ can cause changes in the acid-base balance of the blood; concentrations of 10,000 to $15,000 \mathrm{ppm}$ may cause headaches and giddiness (WHO, 1979). Studies of effects of exposures to elevated concentrations of $\mathrm{CO}_{2}$ have generally involved healthy men and may not be representative of a more diverse population. Thus, $5,000 \mathrm{ppm}$ may not be an acceptable $\mathrm{CO}_{2}$ exposure level for children in a classroom, particularly if there are also significant emissions of pollutants from other indoor sources.

\subsubsection{NIOSH School HHERs}

Forty-six of the 77 NIOSH school HHERs conducted between 1981 and 1994 and assessed for this report had $946 \mathrm{CO}_{2}$ measurements. Three hundred sixty-four or 38 percent of these measurements were in excess of $1000 \mathrm{ppm} \mathrm{CO}$. The measurements ranged from a low concentration of $200 \mathrm{ppm} \mathrm{CO}_{2}$ reported by Anderson and Daniels (1983) to 4375 ppm reported by Berardinelli (1994). Over the 15-year period, $\mathrm{CO}_{2}$ measurements became increasingly common in NIOSH school HHERs as a tool to characterize relative ventilation patterns as indoor environmental investigations shifted from single pollutants to sick building syndrome (SBS) in scope.

\subsubsection{Publications in Scientific Journals, Conference Proceedings, and Government Reports}

Table 6.1 summarizes the $\mathrm{CO}_{2}$ concentration measurements for U.S. and Canadian schools reported in the scientific literature. Measurements are reported for both complaint and non-complaint schools. In many of these reports, concentrations are near or only slightly above the ASHRAE standard of $1,000 \mathrm{ppm}$, regardless of complaint or non-complaint status. $\mathrm{CO}_{2}$ concentrations well above $1000 \mathrm{ppm}$ have also been reported for some non-complaint schools. 
Table 6.1 Concentrations of $\mathrm{CO}_{2}$ Measured in U.S. and Canadian Schools and Reported in the Published Scientific Literature and Government Reports

Study
Bayer and Downing, 1992. Measurements in 3
schools in southeastern U.S. with inadequate
humidity control and consequent mold
problems. $\mathrm{CO}_{2}$ measurements made with a
photoacoustical gas monitor, reported for only
in one school.

Brennan, et al., 1991a. Measurements made in 9 U.S. schools with radon concentrations above $4 \mathrm{pCi} / \mathrm{L}: 3$ in Iowa, 3 in Illinois, 1 in North Dakota, 1 in Maine and 1 in Georgia. Measurements made in the classrooms in midafternoon before students dismissed.

Casey, et al., 1995. $\mathrm{CO}_{2}$ measured in two Las Vegas, $\mathrm{NV}$ elementary schools, in classrooms with heat recovery ventilators (HVR) installed and operating, during the cooling season.

Cousins \& Collett, 1989. Measurements made in 3 Alberta, Canada schools: one constructed prior to 1960 without modification to ventilation system, one constructed prior to 1960 and upgraded to meet current building codes, and one constructed since 1960. Measurements made with direct reading colorimetric detector tubes and a portable infrared analyzer.

Fisher, et al., 1995. 40-hour average weekday $\mathrm{CO}_{2}$ concentrations reported for a school in New Mexico mitigated for high radon concentrations. $\mathrm{CO}_{2}$ concentrations measured continuously.

Thorne, 1993. Measurements made in a problem school (U.S.) with odor complaints. $\mathrm{CO}_{2}$ measurements made with colorimetric detector tubes, before and after mitigation (unblocking of air intakes).
School /Location

School \# 3

9 U.S. schools

with radon $>4$

$\mathrm{pCi} / \mathrm{L}$

\section{Classroom}

School A

School B

Old school:
Renovated school:
New school:
Portable
classrooms

Average:

750

750

650

1950

Pre-mitigation

1000

1900

Room 17

\section{Before Mitigation}

Post-mitigation:

Sump Room

800

1000

Classroom A

1250

Classroom B

Range:

$400-4000$

\section{Range:}

$980-1260$

1110 (a.m.) 1150 (p.m.)

Range:

$500-1100$

$550-1400$

$500-900$

$1000-2800$

a. Values here are estimates based on assumed outdoor air $\mathrm{CO}_{2}$ concentration of $350 \mathrm{ppm}$ since post mitigation values were reported only as percentage of outdoor air $\mathrm{CO}_{2}$.

b. Average of 6 measurements made on 4 different days in one classroom. 
Table 6.1 Concentrations of $\mathrm{CO}_{2}$ Measured in U.S. and Canadian Schools and Reported in the Published Scientific Literature and Government Reports (continued)

\begin{tabular}{|c|c|c|c|}
\hline Study & $\begin{array}{c}\text { School } \\
\text { /Location }\end{array}$ & \multicolumn{2}{|c|}{ Concentrations of $\mathrm{CO}_{2}, \mathrm{ppm}$} \\
\hline $\begin{array}{l}\text { Turk, et al., 1987. Measurements in } 6 \text { non-complaint } \\
\text { schools in Pacific Northwest. Schools ranged from } 3 \text { - } \\
25 \text { years in age, } 1-3 \text { stories; all had mechanical } \\
\text { ventilation systems of some type. } \mathrm{CO}_{2} \text { measured with a } \\
\text { nondispersive infrared spectrometer. }\end{array}$ & $\begin{array}{l}\text { Portland: } \\
\text { Bldg. } 1 \\
\text { Bldg. } 2 \\
\text { Bldg. } 16 \\
\text { Spokane: } \\
\text { Bldg. } 17 \\
\text { Bldg. } 20 \\
\text { Bldg. } 29\end{array}$ & $\begin{array}{c}\text { Average: } \\
840 \\
510 \\
530 \\
520 \\
400 \\
570\end{array}$ & $\begin{array}{c}\text { Range: } \\
307-1290 \\
320-690 \\
410-700 \\
340-670 \\
330-460 \\
480-707\end{array}$ \\
\hline $\begin{array}{l}\text { Turk, et al., 1993. Mitigation of indoor radon levels for } \\
2 \text { schools in Santa } \mathrm{Fe}, \mathrm{NM} \text {; mean } \mathrm{CO}_{2} \text { levels and air } \\
\text { exchange rates reported for the first two schools pre- } \\
\text { and post-mitigation. } \mathrm{CO}_{2} \text { measurements made with a } \\
\text { non-dispersive infrared spectrometer. }\end{array}$ & $\begin{array}{l}\text { SF2, Study room } \\
\text { SF2, Control } \\
\text { room } \\
\text { SF3, Study room } \\
\text { SF2, Control } \\
\text { room }\end{array}$ & $\begin{array}{c}\text { Pre-mitigation } \\
1200 \\
1400 \\
1400 \\
1200\end{array}$ & $\begin{array}{c}\text { Post-mitigation } \\
800 \\
1400 \\
500 \\
1700\end{array}$ \\
\hline $\begin{array}{l}\text { Unpublished draft paper. } \\
\text { Bradstreet, } 1991 \text {. Measurements in } 473 \text { temporary } \\
\text { classrooms (portable and site-built) in non-complaint } \\
\text { schools in Maine. } \mathrm{CO}_{2} \text { levels measured using passive } \\
\text { dosimeter tubes. }\end{array}$ & $\begin{array}{l}1250 \text { dosimeters } \\
\text { mailed; } 473 \\
\text { dosimeters } \\
\text { returned. }\end{array}$ & $\begin{array}{l}\text { Average: } \\
2300 \mathrm{ppm}\end{array}$ & $\begin{array}{l}\text { Percentage } \\
\text { greater than: } \\
1000 \mathrm{ppm}: 79.1 \\
2000 \mathrm{ppm}: 52 \\
5000 \text { ppm: } 6.3\end{array}$ \\
\hline
\end{tabular}

Bayer and Downing (1992) reported an average $\mathrm{CO}_{2}$ concentration that was almost twice the ASHRAE standard (ASHRAE, 1989) for one of the three schools complaint schools which they investigated. Concentrations were not reported for the other two schools. Black and Worthan (1995) reported an average $\mathrm{CO}_{2}$ concentration of $918 \mathrm{ppm}$ for a complaint school. They noted that one room with a malfunctioning ventilation system had very high $\mathrm{CO}_{2}$ concentrations.

Brennan et al. (1991a) reported measurements of $\mathrm{CO}_{2}$ in 9 U.S. schools as part of the U.S. EPA's School Evaluation Program to provide technical assistance to schools with elevated radon concentrations, i.e., above $4 \mathrm{pCi} / \mathrm{L}$. The schools were in Iowa (3 schools), Illinois (3 schools), North Dakota (1 school), Maine (1 school) and Georgia (1 school). Carbon dioxide measurements were made in the classrooms in mid-afternoon before students were dismissed. Concentrations ranged from about $400 \mathrm{ppm}$ up to 5,000 $\mathrm{ppm}$, with a mean of $1480 \mathrm{ppm}$. Seventy-four percent of the rooms had $\mathrm{CO}_{2}$ concentrations above the $1000 \mathrm{ppm}$ ASHRAE guideline (ASHRAE, 1989). It should be noted that the selection of schools was not random. In a later report, Fisher, et al. (1995) reported average weekday $\mathrm{CO}_{2}$ concentrations in two classrooms in a New Mexico school before and after radon mitigation. The average $\mathrm{CO}_{2}$ concentration exceeded $1900 \mathrm{ppm}$ in one of the classrooms prior to radon mitigation.

Casey, et al. (1995) reported $\mathrm{CO}_{2}$ measurements made in two Las Vegas, $\mathrm{NV}$ elementary schools during the cooling season. A heat recovery ventilator (HVR) was installed and operated in one classroom in each school. The second school was a portable, stand alone classroom. Measurements were made and reported for the classroom in School A before the $\mathrm{HRV}$ was operated. The $\mathrm{CO}_{2}$ concentrations were reported to be usually above $5000 \mathrm{ppm}$ at the end of the school day and was still 
higher than $1000 \mathrm{ppm}$ at the beginning of the next day. With the HRVs installed and operating, the two classrooms had $\mathrm{CO}_{2}$ concentrations close to the recommended $1000 \mathrm{ppm}$.

Cousins and Collett (1989) reported $\mathrm{CO}_{2}$ measurements for 3 non-complaint schools in Alberta, Canada. The average concentrations for all three schools were below $1000 \mathrm{ppm}$, although some measurements exceeded this concentration somewhat. However, these investigators reported an average of $1950 \mathrm{ppm} \mathrm{CO} 2$ for the portable classrooms at these schools.

Turk, et al. (1987) found eight hour $\mathrm{CO}_{2}$ averages ranged from 340 to $840 \mathrm{ppm}$ in six Oregon and Washington non-complaint schools. There was a peak 15 minute average of $1290 \mathrm{ppm}$ in one elementary classroom just before afternoon dismissal. One junior high school that was tested twice had mean $\mathrm{CO}_{2}$ concentrations of $520 \mathrm{ppm}$ in the spring (340-670 range) and 641 in the winter (374-863 range). Turk, et al. (1993) reported somewhat elevated $\mathrm{CO}_{2}$ concentrations for two schools in New Mexico prior to radon mitigation measures. The $\mathrm{CO}_{2}$ concentrations were reduced to 800 and $500 \mathrm{ppm}$ for the two study rooms after mitigation, while the control classrooms still had slightly elevated concentrations.

In a draft paper, Bradstreet (unpublished) reported that concentrations of $\mathrm{CO}_{2}$ averaged 2300 ppm for temporary (portable and site built) classrooms in noncomplaint schools in Maine. Seventy-three percent of the $\mathrm{CO}_{2}$ measurements were above $1000 \mathrm{ppm}$ and 6 percent were above $5000 \mathrm{ppm}$. About a quarter (24\%) of the temporary classrooms had heat recovery ventilators (HRV) and those that had the HRV operating averaged $1400 \mathrm{ppm}$. About one-sixth (15\%) had exhaust-only ventilation or recirculation-only fans and these classrooms averaged $2200 \mathrm{ppm}$. About half (46\%) of the temporary classrooms had no mechanical ventilation and these averaged $2700 \mathrm{ppm}$.

Table 6.2 summarizes $\mathrm{CO}_{2}$ concentration measurements reported for some European schools. Most of these measurements were made in non-complaint schools. Many of the measurements were near or above $1000 \mathrm{ppm}$. For two of the schools in Sweden (Norback, 1995) the average concentrations were 1420 and $1850 \mathrm{ppm}$. It should be noted that many of the European measurements were made with colorimetric indicator tubes and so reflect concentrations measured over a very short time interval.

Potting, et al. (1987) reported an epidemiological study involving 339 students in 3 Dutch schools (14 classrooms) with teacher complaints about sick building syndrome symptoms (e.g., headache, eye irritation, sore throat, dizziness, fatigue) and 4 schools without teacher complaints (207 controls). All schools were constructed after 1980. Classroom $\mathrm{CO}_{2}$ levels were high in all of the schools, exceeding the Dutch standard of 1200 ppm during 27 to $97 \%$ of the school time. In one classroom, $\mathrm{CO}_{2}$ levels exceeded $2500 \mathrm{ppm} 73 \%$ of the time. In another classroom, $\mathrm{CO}_{2}$ levels were $1100 \mathrm{ppm}$ at the beginning of one of the school days. There was no relationship between $\mathrm{CO}_{2}$ levels and being a case or control school. Also, there was no relationship between student health symptom complaints and being in a case or control school as determined by teacher health complaints. With the exception of "bad odor of the air," there was no association between students reported health symptoms and classroom $\mathrm{CO}_{2}$ being classified as: high ( 90 to $97 \%$ of the time $>1200 \mathrm{ppm}$ ); medium ( 57 to $81 \%$ of the time $>1200 \mathrm{ppm}$ ); or low ( 27 to $48 \%$ of the time $>1200 \mathrm{ppm}$ ). The authors speculated that the lack of association might be due to the elevated $\mathrm{CO}_{2}$ in all classrooms. Unfortunately, the paper does not state whether the case classrooms were occupied by teachers with complaints or were selected based upon other factors. Also, the paper does not state if the student respondents occupied the monitored classrooms all day or some portion of the school day. 
Table 6.2 Concentrations of $\mathrm{CO}_{2}$ Measured in European Schools and Reported in the Published Scientific Literature

\begin{tabular}{|c|c|c|c|}
\hline Study & Schools & \multicolumn{2}{|c|}{ Concentrations of $\mathrm{CO}_{2}, \mathrm{ppm}$} \\
\hline $\begin{array}{l}\text { Nielsen, } 1984 \text {. Random selection of schools in Denmark; } \\
\text { measurements made in } 2 \text { classrooms for } 3 \text { consecutive days. } \\
\mathrm{CO}_{2} \text { measurement method not reported. }\end{array}$ & 11 schools & $\frac{\text { Average }}{1,000}$ & $\underset{500-1500}{\text { Range }}$ \\
\hline $\begin{array}{l}\text { Norback, et al., } 1990 \text {. Measurements of } \mathrm{CO}_{2} \text { made in } \\
\text { schools in Sweden; } 2 \text { older schools, } 2 \text { newer schools, and } 2 \\
\text { schools with wall-to-wall carpet, all built before the } 1974 \\
\text { energy crisis. } \mathrm{CO}_{2} \text { measurements made with colorimetric } \\
\text { tubes. }\end{array}$ & 6 primary schools & $\frac{\text { Average }}{1290}$ & $\stackrel{\text { Range }}{950-1950}$ \\
\hline $\begin{array}{l}\text { Norback, 1995. Measurements of } \mathrm{CO}_{2}, \mathrm{TVOC}^{*} \text { and } \\
\text { respirable dust made in } 6 \text { Swedish primary schools. } \mathrm{CO}_{2} \\
\text { measurements made with colorimetric tubes. }\end{array}$ & $\begin{array}{c}\text { School No. } \\
1 \\
2 \\
3 \\
4 \\
5 \\
6\end{array}$ & $\begin{array}{c}\text { Average } \\
930 \\
1000 \\
980 \\
880 \\
1420 \\
1850\end{array}$ & $\begin{array}{c}\text { Range } \\
700-1100 \\
900-1200 \\
900-1300 \\
700-1200 \\
1200-1700 \\
1500-2700\end{array}$ \\
\hline
\end{tabular}

Potting, et al., 1987. Epidemiological study in 3 complaint and 4 non-complaint schools (14 classrooms total) in the Netherlands to assess relationships between SBS symptom complaints of children and $\mathrm{CO}_{2}$ levels and indoor climate. All schools were built after $1980 . \mathrm{CO}_{2}$ concentrations were measured continuously with an infrared analyzer. The Dutch standard for indoor $\mathrm{CO}_{2}$ is $1200 \mathrm{ppm} . \mathrm{CO}_{2}$ levels exceeded the guidelines ( $1200 \mathrm{ppm}$ ) for $27 \%$ to $97 \%$ of the time when the classrooms were occupied.

\begin{tabular}{l} 
School No. \\
\hline \\
1 \\
4 \\
5 \\
6 \\
7 \\
8 \\
9 \\
10 \\
11 \\
12 \\
13 \\
14
\end{tabular}

Smedje, et al., 1997. Measurements made in 38 (out of 130) randomly selected schools in Sweden. Measurement method not reported.

\section{Percent of schooltime with $\mathrm{CO}_{2} \geq$ $1200 \mathrm{ppm}:$ \\ Percent of schooltime with $\mathrm{CO}_{2}>$ $2500 \mathrm{ppm}:$}

$$
90
$$

\footnotetext{
* TVOC $=$ total volatile organic compounds
} 
Smedje, et al. $(1996,1997)$ reported the average and range of indoor $\mathrm{CO}_{2}$ concentrations for 96 classrooms in 38 Swedish schools. The schools were randomly selected from a set of 130 schools. Sixty-one percent of the schools had mechanical supply and exhaust air systems while the remainder had natural ventilation. The average concentration of $\mathrm{CO}_{2}$ for the 38 schools was $990 \mathrm{ppm}$. The authors reported that $\mathrm{CO}_{2}$ concentrations were above $1000 \mathrm{ppm}$ for $41 \%$ of the measurements. The maximum concentration reported was $2,800 \mathrm{ppm}$. The authors did not provide information on how the measurements were made or over what time period.

Although the measurements of $\mathrm{CO}_{2}$ in schools which have been reported in the archival scientific literature and government reports are limited in number and scope, they suggest that there is a significant, although undetermined, fraction of schools in both North America and Europe that do not meet the standards for $\mathrm{CO}_{2}$ and ventilation.

\subsubsection{California School Indoor Air Quality Investigations}

Thirty-four of the 70 California school indoor air quality investigations reported carbon dioxide measurements. Some reports present the $\mathrm{CO}_{2}$ results in raw form while others report the data as proportion of measurements greater than $1000 \mathrm{ppm}$ or as peak concentrations. Table 6.3 summarizes much of the data. As far as could be determined, the range of $\mathrm{CO}_{2}$ was from $300 \mathrm{ppm}$ to $4,000 \mathrm{ppm}$ with one reported measurement of $11,500 \mathrm{ppm}$.

Often $\mathrm{CO}_{2}$ concentrations were in excess of $1000 \mathrm{ppm}$ in portable classrooms that had no outdoor air intakes or had ventilation systems that were off, with windows and doors closed due to fan or outdoor noise. Because of the variability in reporting, it is not possible to generalize about $\mathrm{CO}_{2}$ concentrations in California classrooms, or even about complaint classrooms, since reports on only a limited sample of such classrooms could be obtained. However, the elevated $\mathrm{CO}_{2}$ concentrations reported in California for portable classrooms are consistent with data reported for such classrooms by Bradstreet (unpublished) for Maine schools and by Cousins and Collett (1989) for schools in Canada. 
Table 6.3 Reported $\mathrm{CO}_{2}$ Measurements in California Schools from California Schools Reports

\section{Date $^{2}$ and Description Location}

February, 1990. Measurements made with Modular building

Drager colorimetric tubes.

September, 1990. Measurements made with Drager detector tubes. Area samples in two locations in a modular unit with 4 classrooms.

July, 1991. Measurements made in various locations throughout a two-story school building. Measurements made with GasTech IR $\mathrm{CO}_{2}$ monitor. Initial measurements made at noon and 3 p.m. Air conditioning $(\mathrm{AC})$ units modified to add air intake vents. $\mathrm{CO}_{2}$ measurements after $\mathrm{AC}$ modification made at $10 \mathrm{a} . \mathrm{m}$. and 2 p.m.

February, 1992. Measurements of $\mathrm{CO}_{2}$ made for 70 minutes in a modular classroom with a GasTech IR $\mathrm{CO}_{2}$ realtime monitor. Only 6 occupants in room.

March, 1992. Measurements in 2 areas of an office using a GasTech IR $\mathrm{CO}_{2}$ real-time monitor.

November, 1992a. Measurements made over a 2-day period using a GasTech IR $\mathrm{CO}_{2}$ real-time monitor.
Modular unit

300,300

\section{First Floor: \\ Area A \\ Area B \\ Area C \\ Area D \\ Area E \\ Area $F$ \\ Second Floor: \\ Area G \\ Area $\mathrm{H}$ \\ Area I \\ Area J \\ Area $\mathrm{K}$ \\ Area L \\ Area $\mathrm{M}$ \\ Area N}

Times:

2:30 p.m.

2:40 p.m. (AC on)

2:55 p.m.

3:05 p.m. (AC off)

3:30 p.m.

3:40 p.m.

Before AC Retrofit

$$
\begin{gathered}
600,800 \\
600,750 \\
750,700 \\
1000,1000 \\
1100,950 \\
400,350
\end{gathered}
$$

750,600

750,750

950,900

950,900

950,900

950,900

1200,1200

1150,1200

400

450

600

700

950

1050

Inner office:

950

Outer office:

950
Kindergarten building Morning:
Afternoon:

$\mathrm{CO}_{2}, \mathrm{ppm}$

\begin{abstract}
-
\end{abstract}

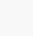


Table 6.3. Reported $\mathrm{CO}_{2}$ Measurements in California Schools from California Schools Reports (continued)

\begin{tabular}{|c|c|c|c|}
\hline \multirow[b]{2}{*}{$\begin{array}{l}\text { November, } 1992 b . \text { Measurements made } \\
\text { in portable classrooms. Method not } \\
\text { reported, but probably Drager tubes. }\end{array}$} & \multirow{2}{*}{$\begin{array}{l}\text { Location } \\
\text { School No. 1 } \\
\text { Room 25 } \\
\text { Room } 24 \\
\text { Room 22 } \\
\text { School No. 2 } \\
\end{array}$} & \multicolumn{2}{|c|}{$\mathrm{CO}_{2}, \mathrm{ppm}$} \\
\hline & & $\begin{array}{c}1000 \\
1000 \\
2000 \\
\\
600 \\
1200\end{array}$ & \\
\hline $\begin{array}{l}\text { February, } 1993 . \text { Measurements made } \\
\text { over a 2-day period using a Gas Tech IR } \\
\mathrm{CO}_{2} \text { real-time monitor. }\end{array}$ & $\begin{array}{l}\text { Two modular } \\
\text { classrooms: } \\
\text { Low (unoccupied): } \\
\text { High (occupied): }\end{array}$ & $\begin{array}{c}350 \\
2500\end{array}$ & \\
\hline $\begin{array}{l}\text { March, } 1993 \text {. Continuous measurements } \\
\text { made over a } 24 \text {-hour period using a } \\
\text { GasTech } \mathrm{IR} \mathrm{CO}_{2} \text { real-time monitor. }\end{array}$ & $\begin{array}{l}\text { School office } \\
\text { building: } \\
\text { Low (unoccupied): } \\
\text { High (occupied): }\end{array}$ & $\begin{array}{l}350 \\
900\end{array}$ & \\
\hline $\begin{array}{l}\text { June, } 1993 \text {. Continuous measurements } \\
\text { made over a week using a GasTech IR } \\
\mathrm{CO}_{2} \text { real-time monitor. }\end{array}$ & $\begin{array}{l}\text { Portable classroom, } \\
\text { middle school: } \\
\text { Low (unoccupied): } \\
\text { High (occupied): }\end{array}$ & $\begin{array}{c}350 \\
2500\end{array}$ & \\
\hline $\begin{array}{l}\text { August, 1993. Continuous measurements } \\
\text { made over a 2-day period using a } \\
\text { GasTech } \mathrm{IR} \mathrm{CO}_{2} \text { real-time monitor. }\end{array}$ & $\begin{array}{l}\text { Two classrooms: } \\
\text { Room \#4: } \\
\text { Room \#9: }\end{array}$ & 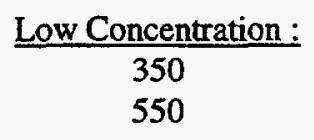 & $\begin{array}{c}\text { High Concentration: } \\
1800 \\
1800\end{array}$ \\
\hline $\begin{array}{l}\text { April, 1994. Continuous measurements } \\
\text { made over a 2-day period using a } \\
\text { GasTech IR } \mathrm{CO}_{2} \text { real-time monitor. }\end{array}$ & Pod \#3: & $\frac{\text { Low Concentration: }}{350}$ & $\frac{\text { High Concentration: }}{1000}$ \\
\hline $\begin{array}{l}\text { August, } 1994 \text {. Continuous measurements } \\
\text { made over a week using a GasTech IR } \\
\mathrm{CO}_{2} \text { real-time monitor. }\end{array}$ & $\begin{array}{l}\text { Office suite: } \\
\text { Facilities area: }\end{array}$ & $\begin{array}{c}\text { Low Concentration: } \\
500 \\
500\end{array}$ & $\begin{array}{c}\text { High Concentration: } \\
850 \\
1000\end{array}$ \\
\hline $\begin{array}{l}\text { December, } 1994 \text {. Continuous } \mathrm{CO}_{2} \\
\text { measurements made in each classroom } \\
\text { from 7:30-15:30 using a Metrosonics IAQ } \\
\text { monitor. }\end{array}$ & $\begin{array}{c}\text { Room Number: } \\
3 \\
5 \\
20 \\
25 \\
26 \\
34 \\
35 \\
44 \\
45 \\
50\end{array}$ & $\begin{array}{c}\text { Average } \\
856 \\
1216 \\
1390 \\
1834 \\
952 \\
922 \\
633 \\
2062 \\
866 \\
573 \\
\end{array}$ & \begin{tabular}{ll}
\multicolumn{2}{c}{ Range: } \\
$320-2571$ \\
$440-1923$ \\
$339-2898$ \\
$387-3211$ \\
$216-2976$ \\
$402-2057$ \\
$529-721$ \\
$469-3970$ \\
$441-1513$ \\
$390-810$
\end{tabular} \\
\hline
\end{tabular}

a. Reports and schools are identified only by the date of the report.

b. Measurements reported for 21 classrooms. Only data reported on p.1 of table listed here. The average concentration of $\mathrm{CO}_{2}$ during occupied periods exceeded the ASHRAE guideline of $1000 \mathrm{ppm} \mathrm{CO}_{2}$ in only half (11/21) of the rooms. An additional 5 rooms had $\mathrm{CO}_{2}$ exceeding $800 \mathrm{ppm}$. 
Table 6.3. Reported $\mathrm{CO}_{2}$ Measurements in California Schools from California Schools Reports (continued)

\begin{tabular}{|c|c|c|c|}
\hline Date $^{a}$ and Description & Location & \multicolumn{2}{|c|}{$\mathrm{CO}_{2}, \mathrm{ppm}$} \\
\hline $\begin{array}{l}\text { measurements made in elementary school } \\
\text { classrooms with Young Environmental } \\
\text { Services monitor. }\end{array}$ & $\begin{array}{l}\frac{\text { Classroon: }}{7} \\
20\end{array}$ & $\begin{array}{c}700 \\
1500\end{array}$ & \\
\hline $\begin{array}{l}\text { January, } 1995 b . \text { Measurements made in } \\
\text { several portable classrooms with Drager } \\
\text { tubes. }\end{array}$ & $\begin{array}{l}\text { Portable classroom: } \\
\text { P } 1 \\
\text { P } 2 \\
\text { P } 3 \\
\text { P } 4\end{array}$ & $\begin{array}{c}\text { Concentration: } \\
1000 \\
1500 \\
900 \\
600 \\
1700 \\
1500 \\
600 \\
2200 \\
700\end{array}$ & $\begin{array}{c}\text { Time of Measurement: } \\
11: 40 \mathrm{am} \\
2: 10 \mathrm{pm} \\
11: 10 \mathrm{am} \\
2: 06 \mathrm{pm} \\
10: 00 \mathrm{am} \\
1: 54 \mathrm{pm} \\
2: 20 \mathrm{pm} \\
11: 00 \mathrm{am} \\
1: 34 \mathrm{pm}\end{array}$ \\
\hline $\begin{array}{l}\text { October, } 1995 . \mathrm{CO}_{2} \text { measurements made } \\
\text { in } 5 \text { selected portable classrooms, } 2 \\
\text { continuously monitored over a day, } \\
\text { Drager tube measurements made between } \\
10 \text { - } 11 \text { am in other } 3 \text { rooms. }\end{array}$ & $\begin{array}{l}\text { Classroom: } \\
304 \\
309 \\
310 \\
317 \\
318\end{array}$ & $\begin{array}{l}600^{\mathrm{b}} \\
3620 \\
1330 \\
600^{\mathrm{b}} \\
2200^{\mathrm{b}}\end{array}$ & \\
\hline $\begin{array}{l}\text { January, } 1996 \text {. Continuous } \mathrm{CO}_{2} \\
\text { measurements made with a GasTech IR } \\
\text { monitor in classrooms in } \mathrm{K} \& 1 \text { st Grade } \\
\text { Building during daytime. Air handling } \\
\text { units had been modified based on } \\
\text { previous investigation that indicated } \\
\text { insufficient ventilation rates. }\end{array}$ & $\begin{array}{l}\text { Room: } \\
24 \\
25 \\
26 \\
23 \\
22 \\
27 \\
20 / 21\end{array}$ & $\begin{array}{c}\text { Minimum Reported: } \\
500 \\
480 \\
480 \\
450 \\
450 \\
500 \\
450\end{array}$ & $\begin{array}{c}\text { Maximum Reported: } \\
650 \\
600 \\
600 \\
600 \\
610 \\
800 \\
975\end{array}$ \\
\hline $\begin{array}{l}\text { February, 1996. Continuous } \mathrm{CO}_{2} \\
\text { measurements made with a GasTech IR } \\
\text { monitor in three portable classrooms over } \\
\text { several days. }\end{array}$ & $\begin{array}{l}\text { Room: } \\
\text { P-22 } \\
\text { P-23 } \\
\text { P-24 }\end{array}$ & $\begin{array}{c}\text { Minimum: } \\
350 \\
350 \\
350\end{array}$ & $\begin{array}{c}\text { Maximum: } \\
1400 \\
2400 \\
2200\end{array}$ \\
\hline
\end{tabular}

a. Reports and schools are identified only by the date of the report.

b. Measurement made with Drager tube

c. $\mathrm{CO}_{2}$ concentrations reported for 2 or 3 times throughout the day - generally about 8:30 a.m., noon, and 3 p.m. 
Table 6.3. Reported $\mathrm{CO}_{2}$ Measurements in California Schools from California Schools Reports (continued)

\begin{tabular}{|c|c|c|c|}
\hline Date $^{2}$ and Description & Location & $\mathrm{CO}_{2}$ & $\overline{p m}$ \\
\hline $\begin{array}{l}\text { April, 1996. Continuous } \mathrm{CO}_{2} \\
\text { measurements made with a GasTech IR } \\
\text { monitor in classrooms in an elementary } \\
\text { school during daytime. }\end{array}$ & $\begin{array}{l}\text { Room: } \\
30 \\
31 \\
\text { Library } \\
6 / 7 \\
4 / 5 \\
3 \\
14 / 15 \\
\text { Multi-purpose } \\
40 \\
41\end{array}$ & $\begin{array}{c}\text { Minimum Reported: } \\
590 \\
600 \\
550 \\
550 \\
550 \\
1150 \\
550 \\
500 \\
850 \\
750 \\
425\end{array}$ & $\begin{array}{c}\text { Maximum Reported: } \\
\mathrm{c} . \\
1100 \\
2850 \\
1300 \\
1650 \\
1300 \\
1500 \\
2000 \\
2100 \\
1100 \\
1500 \\
1250\end{array}$ \\
\hline $\begin{array}{l}\text { June, } 1996 . \text { Continuous } \mathrm{CO}_{2} \\
\text { measurements made with a Young } \\
\text { Environmental Systems monitor in a } \\
\text { complaint and control classroom in an } \\
\text { elementary school during last half day of } \\
\text { school. }\end{array}$ & $\begin{array}{l}\text { Room: } \\
\text { No. } 9: \\
\text { No. } 15 \text { (control): }\end{array}$ & $\begin{array}{l}\text { Range: } \\
400-11,500 \\
500-900\end{array}$ & \\
\hline
\end{tabular}

a. Reports and schools are identified only by the date of the report.

\subsection{Ventilation Rates in Schools}

\subsubsection{Definitions and Standards}

Ventilation is the process by which air is supplied and removed from an enclosed space by natural or mechanical means for the purpose of controlling air contaminant levels, humidity and/or temperature. In this review, the term ventilation rate is used to refer only to the rate at which outside air is supplied to the occupied space as opposed to recirculated air." Natural ventilation occurs through infiltration (and exfiltration) of outdoor air through cracks and small openings in the building shell or through opening windows, doors or non-powered ventilators. Infiltration is generally driven by wind and thermal forces, e.g., pressure differences caused by indoor and outdoor temperature differences (the stack effect). Infiltration can also be driven by pressure differences induced by fans.

ASHRAE Standard 62-1989 (ASHRAE, 1989) recommends a minimum ventilation rate of 15 $\mathrm{cfm} /$ person $(8 \mathrm{~L} / \mathrm{s}$-person) for classrooms. This standard also specifies a default assumption occupancy of 50 persons per $1000 \mathrm{ft}^{2}\left(20 \mathrm{ft}^{2} /\right.$ person) for schools. For more typical values of about $35 \mathrm{ft}^{2} /$ person and a ceiling height of about $8.5 \mathrm{ft}$, the current ASHRAE standard would require an air exchange rate of about 3 air changes per hour $(\mathrm{ACH})$ for a classroom. This standard is based on odor acceptability of the indoor air.

\footnotetext{
* The term ventilation rate is sometimes used to refer to the rate at which total conditioned air is supplied to a space, i.e., both recirculated and outside air.
} 
Ventilation rates are commonly measured by releasing a tracer gas (e.g., $\mathrm{SF}_{6}$ ) inside a building and then measuring its concentration decay over time due to the exchange of outdoor for indoor air. The tracer gas should be well mixed within the indoor space before decay measurements are begun. Ventilation rates can also be measured with tracer gases using the constant injection method or the constant concentration method. All three methods are based on conservation of mass. Flow hoods and anemometers are sometimes used to measure the rate at which supply air is provided through an air inlet to a space. These measurements, however, are not necessarily identical with what would be measured using a tracer gas since the air supply may include recirculated as well as outdoor air. The indoor concentration of $\mathrm{CO}_{2}$ is often used to infer ventilation rates. There are, however, several important caveats regarding such use (Persily and Dols, 1990). In particular, there can be very significant errors in ventilation rates estimated from instantaneous $\mathrm{CO}_{2}$ measurements unless the $\mathrm{CO}_{2}$ within a building has reached equilibrium and is uniform throughout the building. In many buildings, $\mathrm{CO}_{2}$ concentrations never reach the equilibrium value. In these buildings, active ventilation rates are less than the rate implied by the maximum $\mathrm{CO}_{2}$ concentration.

In 1994, $27 \%$ of U.S. school officials rated ventilation as unsatisfactory in their schools and $19 \%$ rated indoor air quality as unsatisfactory, according to a national survey conducted by the U.S. General Accounting Office (1995). These ratings, however, were based on perception rather than actual measurements of ventilation rates.

\subsubsection{NIOSH School HHERS}

Most NIOSH school investigations did not measure ventilation rates other than using $\mathrm{CO}_{2}$ as a screening tool to estimate relative ventilation rates. The exceptions appear to be five of the NIOSH school investigators: Burkhart, et al. (1992), Hanley, et al. (1992), and Kiefer, et al. (1993) who used flowhoods; and Crandall and Wilcox (1992) and Elliot and Baron (1991), who reported making air flow measurements by an unspecified method. Burkhart, et al. (1992) found that the ventilation rate was 4.3 $\mathrm{cfm} /$ person and $6.3 \mathrm{cfm} /$ person in two wings of a complaint school. Hanley, et al. (1992) found that the total supply air flows at minimum and maximum temperature settings had been substantially improved in a school that had been partially mitigated.

Burr and Malkin (1996) described a Midwest complaint school that was opened in 1990 with a ventilation system that was designed to provide $5 \mathrm{cfm}$ of outside air (OA) per person. After modification of the ventilation system to provide an average of $12 \mathrm{cfm}$ of OA/person, Burr and Malkin indicated that staff health symptoms were about half as frequent as before. Indoor concentrations of $\mathrm{CO}_{2}, \mathrm{TVOCs}$, and formaldehyde were also reduced. Although not supported by the data they present, the authors state, “. . factors other the amount of outside air introduced into the occupied space may contribute to the development of symptoms of building occupants."

\subsubsection{Publications in Scientific Journals, Conference Proceedings and Reports}

As early as 1977 , it was generally known that infiltration alone would not provide adequate ventilation of school classrooms (Liu, et al., 1977). Yet, in 1990, Leovic (1990) reported that in EPA's early radon diagnostic work in 13 schools with high radon concentrations in Alabama, Maryland, New York, and Tennessee, EPA found that many school HVAC systems were not designed to deliver conditioned outdoor air to occupied spaces. 
Table 6.4 summarizes reports of ventilation measurements made in U.S. and European schools. Casey, et al. (1995) described a project involving four "typical" Las Vegas classrooms in two schools that had essentially no outside air supply. The initial ventilation rates, measured using $\mathrm{SF}_{6}$, averaged 0.2 air changes per hour (ACH) in both classrooms in School A and $0.7 \mathrm{ACH}$ in both classrooms in School B. After heat recovery ventilators were installed in two of the classrooms, the ventilation rates increased from 0.2 to 2.9 and 0.7 to 3.4 .

Lagus Applied Technology (1995) recently reported air change rates measured in 14 California schools in four climate zones, including 9 built or retrofitted before and 5 built or retrofitted after the 1987 State Energy Code became effective. The typical California K-12 classroom had an exterior door, was windowless, and had an air handler that was controlled by the teacher. Sometimes the air handler would be turned off due to noise or it only provided outdoor air when it was heating or cooling. The buildings were tested using three tracer gas methods when the schools were unoccupied but under "normal" occupied operating conditions as well as with outdoor air set as low as possible for the building's HVAC control system.

The median air change rate reported for these California schools under normal operating conditions was $2.24 \mathrm{ACH}$ and ranged from 0.6 to $7.49 \mathrm{ACH}$. Nine of the 14 schools had air change rates below $2.5 \mathrm{ACH}$. About $20 \%$ of the schools had air change rates less than half of the value required to meet the current ASHRAE recommendation. The California buildings built or retrofitted after 1987 had lower total air change rates and infiltration rates (by an average of 30\%) than those built or retrofitted before that year. Of the schools built after 1987, 3 out of 5 had air change rates less than two-thirds of the recommended rate.

Turk, et al. (1987b, 1989) reported ventilation measurements made in 6 non-complaint schools in the U.S. Northwest - 2 in Portland, OR and 4 in Spokane, WA - using the $\mathrm{SF}_{6}$ tracer gas decay method. Schools ranged from 3 - 25 years in age, 1 - 3 stories; all had mechanical ventilation systems of some type. Ventilation rates, calculated on a whole building volume basis, ranged from $4.5 \mathrm{~L} / \mathrm{s}$-person to 31 L/s-person (9.6 to $66.2 \mathrm{cfm} /$ occupant). The whole or average building rate, however, includes unoccupied areas such as hallways and gymnasiums, and, as the authors point out, this average rate overestimates the local ventilation rate of occupied classrooms. For example, in one of the elementary schools, the whole building ventilation rate was $9.6 \mathrm{cfm} /$ person $(4.5 \mathrm{~L} / \mathrm{s}$-person) while an occupied classroom was only $3.4 \mathrm{cfm} /$ person $(1.6 \mathrm{~L} / \mathrm{s}$-person).

Turk, et al. (1993) also reported ventilation rates measured in 2 schools in Sante Fe, NM, which were being mitigated for high radon concentrations. Pre- and post radon mitigation ventilation rates were below $3 \mathrm{ACH}$ with one exception.

Shaughnessy, et al. (1993) reported that classrooms in a non-mechanically ventilated New Mexico school had carbon dioxide levels that exceeded $4000 \mathrm{ppm}$ and ventilation rates ranged from 0.06 to $0.2 \mathrm{ACH}$ and 0.4 to $1.0 \mathrm{cfm} /$ person before mitigation based upon $\mathrm{SF}_{6}$ measurements (the lower reported values are below the lower limit of quantification of the method). After mitigation, carbon dioxide was less than $1000 \mathrm{ppm}, \mathrm{ACH}$ was 0.2 to $4.6 \mathrm{ACH}$. 
Table 6.4. Outside Air Ventilation Rates Measured in Schools in the U.S. and Europe and Reported in the Published Scientific Literature or Reports

\begin{tabular}{l}
\hline \multicolumn{1}{c}{ Study } \\
\hline Measurements in U.S. Schools: \\
Casey, et al., 1995. Ventilation rates in two Las Vegas, \\
NV elementary schools, in a classroom with a heat \\
recovery ventilator (HVR) installed and an adjacent \\
control classroom without an HRV, during the cooling \\
season. Measurements made with SF $_{6}$ tracer gas.
\end{tabular}

Lagus Applied Technology, 1995. Outside air ventilation rates for 14 California schools, in 4 major climate zones of California. Schools included elementary, middle, high school and community colleges. $\mathrm{SF}_{6}$ tracer gas used for measurements.

Shaughnessy, et al., 1993. Ventilation rates reported for non-mechanically ventilated New Mexico school classrooms in which radon mitigation was being carried out. Ventilation rates measured with $\mathrm{SF}_{6}$ tracer gas.

Turk, et al., 1987b, 1989. Outside air ventilation rates measured for 6 schools in the Pacific Northwest. SF $_{6}$ tracer gas decay method used. (Whole building ventilation rates).

Turk, et al., 1993. Mitigation of indoor radon for 2 schools in Sante $\mathrm{Fe}, \mathrm{NM}$. Mean $\mathrm{CO}_{2}$ levels and air exchange rates reported for the first two schools pre- and post-mitigation.

.

\begin{tabular}{|c|c|}
\hline \multicolumn{2}{|c|}{ Ventilation Rates * } \\
\hline & Averages: \\
\hline Classroom & No HRV With HRV \\
\hline
\end{tabular}

School A, Test Room
$0.2 \mathrm{ACH}^{\mathrm{a}} \quad 2.9 \mathrm{ACH}$
$0.2 \mathrm{ACH} \quad \mathrm{NA}^{\mathrm{b}}$.

School A, Control Room

School Bc. Test Room

$0.7 \mathrm{ACH} \quad 3.4 \mathrm{ACH}$

School B ${ }^{c}$, Control Room

$0.7 \mathrm{ACH} \quad \mathrm{NA}^{\mathrm{b} .}$

Median:

Quartiles:

$2.24 \mathrm{ACH}$

$1.63,2.82 \mathrm{ACH}$

Range, Pre-mitigation:

Range, Post-mitigation:

$0.06-0.2 \mathrm{ACH}$

$0.2-4.6 \mathrm{ACH}$

School:
No.1
No. 2
No. 3
No. 4
No. 5
No. 6

$\frac{\text { Rate, } L / \text { s-person }{ }^{\mathrm{d}} \text { : }}{4.5}$

4.5

6.5

9.9

31

13

29

Pre-mitig. Post-mitig.

\section{School/ \\ Classroom}

SF2, Study room

SF2, Control room

$0.1 \mathrm{ACH}$

$0.4 \mathrm{ACH}$

$0.2 \mathrm{ACH} \quad 0.4 \mathrm{ACH}$

SF3, Study room

SF2, Control room

$0.2 \mathrm{ACH} \quad 3.7 \mathrm{ACH}$

$0.2 \mathrm{ACH} \quad 0.2 \mathrm{ACH}$

\section{Measurements in European Schools}

Nielsen, 1984. Random selection of 11 schools in

Denmark; measurements made in 2 classrooms for 3 consecutive days.

Average:

$6.4 \mathrm{~L} / \mathrm{s}$-person
Range:

$1.8-15.4 \mathrm{~L} / \mathrm{s}$-person

* ASHRAE Standard 62-1989 (ASHRAE, 1989) for Classrooms: $8 \mathrm{~L} / \mathrm{s}$-person. With typical occupancy, the current ASHRAE Standard 62 would recommend a minimum air change rate of $3 \mathrm{ACH}$ for school classrooms.

2. $\mathrm{ACH}=$ air changes per hour

b. NA = Not applicable (no HRV installed in control classroom)

c School B classrooms were both free standing portable classrooms.

d. Based on the total volume of the building. 
Nielsen (1984) reported ventilation measurements made in a random selection of 11 schools in Denmark. Measurements were made in 2 classrooms for 3 consecutive days. The average ventilation rate was $6.4 \mathrm{~L} / \mathrm{s}$-person with a range of $1.8-15.4 \mathrm{~L} / \mathrm{s}$-person.

\subsubsection{California School Indoor Air Quality Investigations}

As reported earlier, 34 of the 61 California schools investigations used $\mathrm{CO}_{2}$ as an indicator of ventilation rates and with one or two exceptions, they did not measure ventilation rates via air flow. In one school in which there were concerns about the spread of tuberculosis (TB) among the student body, ventilation measurements were made in 47 classrooms and in a number of offices, laboratories, other rooms, to determine the number of air changes per hour. The method used to determine air changes per hour was not described. A smoke aerosol was also used to visually determine the degree of air mixing in various areas. The median air exchange rate for the 28 classrooms on the second floor was about 1.4 $\mathrm{ACH}$, with a minimum of $0.5 \mathrm{ACH}$ and a maximum of $1.4 \mathrm{ACH}$. For typical classroom occupancies, this is less than half of the ASHRAE guideline of $3 \mathrm{ACH}$. At the median air exchange rate of 1.4, approximately 1.5 hours would be required to remove $90 \%$ of an air contaminant, e.g., a TB contaminated aerosol, via ventilation. For the 16 classrooms on the third floor, the median air exchange rate was about $5.2 \mathrm{ACH}$, with a minimum of $2.8 \mathrm{ACH}$ and a maximum of $6.4 \mathrm{~h}^{-1}$. Ninety percent removal of an air pollutant at the median air exchange rate for these classrooms would require about a half hour.

Although there were few California schools in which ventilation rates were measured, many of the California schools investigations reported that the ventilation system delivered fresh air only when the occupied space was heated or cooled. For some systems, the fan for the HVAC could be manually operated but teachers reported turning the fans off because of noise. Overall, ventilation problems were the most commonly reported problem for these schools.

\subsection{Summary}

In general, the $\mathrm{CO}_{2}$ measurements that have been reported in schools suggest many classrooms probably do not meet the ASHRAE Standard 62-1989 for minimum ventilation rate, at least part of the time, and that this situation may be more acute in portable classrooms. However, there have not been any statistically based surveys of a wide group of classrooms that would provide information on the distribution of $\mathrm{CO}_{2}$ concentrations in schools on statewide, regional, or national basis.

Measurements of ventilation rates in schools have been much more limited than for $\mathrm{CO}_{2}$. However, one of the largest sets of measurements is for California schools (Lagus Applied Technology, 1995). Although this is not a random subset of California schools, it is probably reasonably representative. The median ventilation rate measured in these 14 California schools under typical occupied conditions was $2.24 \mathrm{ACH}$. Nine of these 14 schools had air change rates below 2.5 ACH. This is below the minimum of $3 \mathrm{ACH}$ value implied by ASHRAE Standard 62-1989 for a typical classroom occupancy of about $1000 \mathrm{ft}^{2} / 28$ persons.

Ventilation rates which have been reported for U.S. schools with high radon concentrations are also generally below the recommended rate, but it is not known how representative the high radon schools are of schools in general. For the six schools in the Pacific Northwest for which measurements were made (Turk, et al., 1987b, 1989), two out of six of the schools had whole building ventilation rates 
below the current ASHRAE Standard 62-1989 of 7.5 L/s-person. These reported data strongly suggest that ventilation rates in many schools are likely to be below the recommended standard.

Some of the schools in which there was evidence of elevated $\mathrm{CO}_{2}$ concentrations and/or inadequate ventilation rates were from sets of randomly selected schools. This suggests that inadequate ventilation may be a fairly common problem in schools, including those in California. Concentrations of a variety of pollutants emitted by the occupants and building materials and furnishings will be higher under these conditions than if the ASHRAE ventilation standard were being met. Of particular concern is the potential for increased risks of contracting certain infectious diseases, such as influenza and tuberculosis, in classrooms in which the rate of ventilation with outdoor air does not meet the ASHRAE standard. 


\subsection{AIRBORNE POLLUTANTS IN SCHOOLS}

\subsection{Overview}

The environmental measurements that were made in schools in the NIOSH, California, and broader scientific investigations included those involving airborne pollutants, ventilation rates and thermal conditions. This review focused on airborne pollutants that could account for the types of symptoms most commonly reported in HHERs and other literature, that is, acute or short-term symptoms and health complaints. The airbome pollutants considered in depth were: volatile organic compounds (VOCs), formaldehyde, carbon monoxide (CO), and microbiological pollutants, including bioaerosols. However, ozone and particulate matter are also considered.

Table 7.1 summarizes the frequency of measurements for the most commonly measured pollutants in the NIOSH HHERs, the studies reviewed by ICF Kaiser, and the reports on indoor air quality in California schools. The most frequent indoor air quality measurement was for $\mathrm{CO}_{2}$, followed by measurements of VOCs and formaldehyde. Measurements of microbiological pollutants and carbon monoxide were also made in some of these investigations, although generally less frequently. For the NIOSH HHERs, in addition to the pollutants listed in Table 7.1, there were some measurements made for ethylene oxide, hydrocarbons, PCBs, metals, silica, fluorides, solvents, acetic acid, nitrogen dioxide, and sulfur dioxide. ICF Kaiser's (1994) assessment of 23 school IAQ studies found that all included air pollution measurements (Table 7.1), most commonly for $\mathrm{CO}_{2}$, VOCs, formaldehyde and CO. In addition, ICF Kaiser analyzed 112 newspaper articles from 1983 to 1994 on indoor air quality in 194 schools in 26 states. They found that the pollutants of reported concern also included asbestos, herbicides, lead, bioaerosols (bacteria, mold), particulate matter, and pesticides. However, it is unclear to what extent there were actually measurements made for these pollutants. In the 54 California indoor air quality reports involving schools investigations, 36 reported measurements of air pollutants as listed in Table 7.1.

Table 7.1 Frequency of Airborne Pollutant Measurements by Study Group

\begin{tabular}{lccc}
\hline Pollutant & $\begin{array}{c}\text { NIOSH HHERs } \\
(\mathbf{N = 7 2})\end{array}$ & $\begin{array}{c}\text { ICF Kaiser } \\
(\mathbf{N}=\mathbf{2 3})\end{array}$ & $\begin{array}{c}\text { California Investigations } \\
(\mathbf{N}=\mathbf{6 1})\end{array}$ \\
\hline Carbon Dioxide & $60 \%^{\mathrm{n}}$ & $87 \%^{\mathrm{n}}$ & $56 \%^{\mathrm{n}}$ \\
Volatile Organic Compounds & 35 & 48 & 15 \\
Formaldehyde & 23 & 48 & 28 \\
Microbiological pollutants & 8 & -- & 5 \\
Carbon Monoxide & 16 & 61 & 8 \\
Airborne particulate matter & 2 & - & 11 \\
Ozone & 1 & - & 5 \\
\hline
\end{tabular}

$\mathrm{N}=$ Number of investigations, generally each represents a single school

$\mathrm{n}=$ percent of all studies in each group measuring for a specific pollutant 
It should be noted that many of the air pollutant measurements in the California school reports and the NIOSH HHERs as well as studies cited by ICF and other scientific investigations were short-term grab samples rather than measurements made over an entire school day during occupied periods. Sometimes, the grab samples were taken to capture what was expected to be worst-case concentrations (e.g., carbon dioxide, temperature, and relative humidity measured at the end of the occupied period) while in other cases the grab samples were taken at different times of the day. Some of the more recent studies, including recent HHERs, have involved measurements using continuous monitors. The different sampling protocols and methods limit comparisons of the measurements between the studies.

\subsection{Volatile Organic Compounds}

\subsubsection{Introduction}

The term volatile organic compounds is used to refer to a range of organic compounds with boiling points between about $50^{\circ}$ to $250^{\circ} \mathrm{C}$, which are generally sampled from air using some type of sorbent, e.g., Tenax, charcoal. Examples of VOCs include benzene, toluene, n-nonane, styrene, hexanal, butanol, 2-butoxy ethanol. Many of these compounds are used as industrial solvents and/or starting materials in the manufacture of building materials and furnishings as well as consumer products. Common indoor sources of VOCs include carpeting, adhesives, building materials (especially when new), copier toner, solvents, paints, cleaners, pest control products, cooking, tobacco smoke, fabrics, and humans. Many VOCs are also found in outdoor air, although typically at concentrations 2-10 times lower than in indoor air.

The VOCs are suspected as one of the causes of SBS, in part because industrial workers exposed to many of the same VOCs as those measured in buildings experience some of the same kinds of symptoms as observed for SBS, e.g., eye, nose and throat irritation. However, industrial workers are usually exposed to only one or two VOCs at very high concentrations. In buildings, occupants are typically exposed to perhaps a hundred or more VOCs, each at a concentration that is about $1 / 1000$ th of the concentration known to cause such symptoms. For this reason, it has been suggested that the total concentration of all VOCs is what is important, i.e., total VOC (TVOC). The TVOC concentration is defined as the total mass of measured VOCs per unit volume of air, exclusive of very volatile and highly reactive organic compounds such as formaldehyde. Measured values of TVOC vary significantly depending upon the sampling and analysis methods used (Hodgson, 1995). Despite this variability, TVOC is often a useful measurement in complaint buildings.

Concentrations of TVOC in buildings are typically about $0.5 \mathrm{mg} / \mathrm{m}^{3}$, although in some buildings concentrations reach levels of $2-10 \mathrm{mg} / \mathrm{m}^{3}$. For these buildings, there is some evidence of higher SBS symptom rates. There is also evidence from environmental chamber experiments with humans (Molhave, 1986; Molhave, et al., 1991) that these levels of simple mixtures of VOCs can cause some of the SBS symptoms. Based on environmental chamber exposures of humans to mixtures of VOCs, Molhave (1990) has suggested the following as guidelines for TVOC concentrations in indoor air:

- less than 0.2 milligrams per cubic meter $\left(\mathrm{mg} / \mathrm{m}^{3}\right)$ - the comfort range, no irritation or discomfort 
- 0.2 to $3.0 \mathrm{mg} / \mathrm{m}^{3}$ - multifactorial range in which VOC exposures can contribute, along with other factors, to symptoms of irritation and discomfort;

- 3 to $25 \mathrm{mg} / \mathrm{m}^{3-}$ the discomfort range, will probably cause irritation and discomfort;

- $25 \mathrm{mg} / \mathrm{m}^{3}$ - the toxic range

In reviewing reports of TVOC measurements in schools, we have compared measured data to the Molhave guidelines and to TVOC concentrations reported for U.S. office buildings, since there is a growing data base for office buildings. In some cases, we have also commented on the probable bias of the sampling method with respect to the measured value of TVOC. For example, in many of the reported investigations of indoor air quality, measurements of VOCs were made using methods developed for industrial settings with very high levels of TVOC. The limits of detection for these methods are often close to or above TVOC concentrations commonly found in non-industrial indoor environments and thus, are not appropriate.

\subsubsection{NIOSH School HHERs}

TVOC measurements were reported in 27 of 77 NIOSH school HHERs. In many cases, the results were at or near the limit of detection or quantification or otherwise not unusual for indoor environments and well below industrial criteria (cf. Crandall and Wilcox, 1992; Hanley, et al., 1991). However, there were a number of HHERs for which TVOC concentrations were near or above levels at which eye, nose and throat irritation, and possibly headaches might be observed. Kelly (1992a) found TVOC concentrations between 0.2 and $3.0 \mathrm{mg} / \mathrm{m}^{3}$ in one school, which might cause eye, nose, and upper respiratory irritation and discomfort. These levels were found eight months after an organic mastic remover solvent had been used on a floor as part of an asbestos tile removal project. School personnel subsequently attempted to mask the odor with deodorizers--which can emit additional VOCs---as well as unsuccessfully attempted to seal the contaminated floor. In another school, Kelly (1992b) found TVOC concentrations between 3 and $25 \mathrm{mg} / \mathrm{m}^{3}$. These are concentrations that would probably cause irritation and discomfort, and possibly headaches. The source of the VOCs was suspected to be solvents that had been used to remove floor tile mastic during Thanksgiving and Christmas breaks.

Similarly, Burr, et al., (1993) found TVOCs averaged $8 \mathrm{mg} / \mathrm{m}^{3}$ in classrooms and offices some of which were attributed to a liquid dispersant used in photocopiers. Blade (1992) also reported branched aliphatic hydrocarbons at $60 \mathrm{mg} / \mathrm{m}^{3}$ near a photocopier in a school office. This concentration is well below industrial criteria for exposures but greatly exceeds concentrations normally found in nonindustrial indoor environments. Burkhart, et al. (1992) reported finding low levels of VOCs (xylene, toluene, styrene) in a school while ceilings were being painted in August.

For these HHERs, TVOC concentrations were at the high end of values which have been reported to U.S. office buildings. The geometric mean TVOC concentration reported for 12 office buildings in northern California (Daisey, et al., 1994) was $510 \mu \mathrm{g} / \mathrm{m}^{3}$ (range: 230 to $7,000 \mu \mathrm{g} / \mathrm{m}^{3}$, with the two highest concentrations observed for buildings with wet-process photocopiers. The average concentration of the sum of the VOCs sampled in 16 U.S. office buildings, randomly selected without regard to complaint status, was $303 \mu \mathrm{g} / \mathrm{m}^{3}$ (Range: 33 to $2108 \mu \mathrm{g} / \mathrm{m}^{3}$ ) (Brightman, et al., 1996). Samples were collected in Summa canisters and analyzed by gas chromatography/mass spectrometry. 


\subsubsection{Publications in Scientific Journals and Conference Proceedings}

There have been very few measurements of TVOCs in schools reported in the scientific archival literature. These are summarized in Table 7.2. For the U.S., we found only three papers which reported TVOC measurements, all involved complaint schools. Bayer and Downing (1992) reported TVOC concentrations which ranged from about 1,000 to $23,000 \mu \mathrm{g} / \mathrm{m}^{3}$ for one school and an average of 1,600 $\mu \mathrm{g} / \mathrm{m}^{3}$ for another. Both schools were located in the southeastern U.S. and were described as having problems with humidity control and mold. Black and Worthan (1995) reported average TVOC concentrations of 454 and $220 \mu \mathrm{g} / \mathrm{m}^{3}$ under unoccupied and occupied conditions, for problem school in Washington state after mitigation. The higher TVOC level during the unoccupied condition may have been related to a lower ventilation rate, but the authors do not provide this information. Casey, et al. (1995) reported TVOC measurements made in two Las Vegas, NV elementary schools during the cooling season. The ventilation systems for the classrooms had been disabled for unknown reasons and the only means of ventilation was infiltration. Measurements were made before and after the installation of a heat recovery ventilator (HVR) in the test classroom in each school. TVOC levels before the installation and operation of the HRVs ranged from 800 to $2,000 \mu \mathrm{g} / \mathrm{m}^{3}$. In the second week of the experiment, with the HRV operating, concentrations of TVOC were reduced to $750 \mu \mathrm{g} / \mathrm{m}^{3}$ and $450 \mu \mathrm{g} / \mathrm{m}^{3}$ in the two classrooms with the HRVs operating. Concentrations in the two control classrooms did not change significantly.

Cavallo, et al. (1993) and Laurent, et al. (1993) reported TVOC concentrations for noncomplaint schools in Italy and France, respectively. The median concentration reported for the Italian nurseries and kindergartens $\left(3,625 \mu \mathrm{g} / \mathrm{m}^{3}\right)$ is within the range for which irritant symptoms, and possibly headaches might be expected (Molhave, 1990). The median concentration for the Italian primary and secondary schools was lower $\left(265 \mu \mathrm{g} / \mathrm{m}^{3}\right.$ ) but the upper end of the range was very high, $13,600 \mu \mathrm{g} / \mathrm{m}^{3}$. The average for the 10 French schools was $980 \mu \mathrm{g} / \mathrm{m}^{3}$, which is relatively high. The samples in the French schools were collected on Tenax, while the Italian investigators used Carbotrap, which has a higher breakthrough volume. Thus, higher TVOC concentrations might have been measured in the French schools if Carbotrap had been used for sample collection.

Norback (1995) reported TVOC concentrations measured in 36 classrooms in 6 Swedish primary schools. The range of average concentrations for the six schools was quite low, 70 to $182 \mu \mathrm{g} / \mathrm{m}^{3}$. The low concentrations measured in the Swedish schools may have been due to the use of charcoal sorbent for sample collection and short sampling times ( 2 hours). Recoveries of volatile organic compounds from charcoal with carbon disulfide depend upon the total mass collected on the charcoal, i.e., recoveries are generally lower at lower mass loadings.

\subsubsection{California School Indoor Air Quality Investigations}

In nine of the California schools, measurements were made of individual VOCs or of TVOC, with the highest TVOC concentration of $2.9 \mathrm{mg} / \mathrm{m}^{3}$ reported for a portable classroom. At this concentration, some of the occupants might have experienced eye, nose and throat irritation and other SBS symptoms. None of the measurements of individual VOCs were unusual. 
Table 7.2. Concentrations of TVOC Measured in U.S. and European Schools and Reported in Scientific Literature

$\frac{\text { Study }}{\text { Bayer and Downing, 1992. } 3 \text { schools in }}$ southeastern part of U.S. with humidity control and mold problems.

Black and Worthan, 1995.

Measurements made in an IAQ complaint school in Washington state after mitigation. Measurement method not specified.

Casey, et al., 1995. TVOC measured in two Las Vegas, NV elementary schools, in a classroom with a heat recovery ventilator (HVR) installed and an adjacent control classroom without an HRV, during the cooling season. Samples collected with multisorbent samplers; analysis by flame ionization detection or GC/MS.

Cavallo, et al., 1993. Measurements in 10 schools in Milan, Italy. VOCs collected on Carbotrap for 5 hours, thermally desorbed and analyzed by gas chromatography/flame ionization detector.

Laurent, et al., 1993. Measurements made in 10 schools in Paris to assess indoor air quality. VOC samples collected on Tenax for 1-2 hours; thermally desorbed and analyzed by gas chromatography/mass spectrometry.

Norback, 1995. Measurements of TVOC made in 6 Swedish primary schools in 36 classrooms; four 2-hour samples collected between 12:30 and 14:30. Samples collected on charcoal sorbent, extracted with $\mathrm{CS}_{2}$ and analyzed by gas chromatography/flame ionization detector.

${ }^{2} \mathrm{NR}=$ Not reported

b. School B classrooms were both free standing portable classrooms.

School/Location

School No. 3:

Baseline(before

occupancy):

After occupancy:

\section{Classroom}

School A, Test Room

School A, Control

School B b. Test Room

School B ${ }^{\mathrm{b}}$, Control

Nurseries \&

kindergartens (16

samples):

Primary \& secondary

(24 samples):

\section{6 primary and 4 nursery schools}

School No. 2:

TVOC, $\mu g / \mathrm{m}^{3}$

$\frac{\text { Average: }}{\text { NR }}$

1,600

Average:

454

220

Range:

$-1,000-\frac{23,000}{2}$

$\mathrm{NR}^{2}$

Range:

$13-1,375$

$<1-485$

\section{Week 1, No HRV operating}

1,750

2,000

800

1,250

Median:

3,625

265

Average:

980

School No.

1

2

3

4

5

6
Average

182

125

99

70

120

173
Week 2, With HRV operating in Test Room 750

1,950

450

1,450

Range:

$280-11,300$

$5-13,600$

Maximum:

1,700

(for a newly built school) 


\subsection{Formaldehyde}

\subsubsection{Introduction}

Formaldehyde is classified separately from the VOCs because the sampling and analysis for this compound requires a different method from those used for VOCs. This compound is widely used in the manufacture of building materials, e.g., particleboard, furnishings, and permanent press finishes for fabrics, and has sometimes been found in indoor air at levels that can cause eye, nose and throat irritation as well as lower airway and pulmonary effects (Samet, et al., 1988). In more recent years, manufacturing processes have changed and particleboard based furnishings are generally coated to reduce formaldehyde emissions. Formaldehyde also was formerly used to preserve biological specimens and thus, could often be found in the air in biology laboratories during dissection experiments. Such specimens are now prepared with other preservatives that are less irritating and odorous.

The World Health Organization (WHO, 1987) indoor air quality guideline for formaldehyde is that indoor concentrations should not exceed $100 \mu \mathrm{g} / \mathrm{m}^{3}(0.08 \mathrm{ppm})$ for a 30 minute exposure, based on annoyance (irritant) effects. The Canadian target level (acceptable level) for formaldehyde in residential indoor air is $0.05 \mathrm{ppm}$ (Canada Department of National Health and Welfare, 1987). The California Department of Health Services (DHS, 1983) has also recommended that indoor concentrations of formaldehyde in non-industrial settings should not exceed $0.05 \mathrm{ppm}$.

\subsubsection{NIOSH School HHERs}

Formaldehyde (HCHO) measurements were reported in 18 of the 77 NIOSH school HHERs. The sampling and analysis methods ranged from very short-term samples collected with Drager Direct Reading Detector Tubes, with a lower limit of detection (LOD) of $0.5 \mathrm{ppm}$, to samples collected over 8 hour periods and analyzed using methods with LODs of 0.005 to $0.01 \mathrm{ppm}$. The latter types of methods have adequate sensitivity to detect concentrations above the $0.05 \mathrm{ppm}$ level of acceptability discussed above.

For the 15 HHERs for which formaldehyde measurements were made and reported, $18 \%$ (24 out of 137) of the measurements exceeded the California DHS (1983) recommended maximum of $0.05 \mathrm{ppm}$. One-third of these elevated measurements were in a single school and were attributed to HCHOpreserved dissection specimens in biology laboratories (Zey, 1985). Another nine of the 24 elevated measurements were in Pennsylvania school that had been insulated five years earlier with ureaformaldehyde insulation (Lee, 1986). Urea-formaldehyde insulation is no longer used because of problems with formaldehyde emissions.

\subsubsection{Publications in Scientific Journals and Conference Proceedings.}

Table 7.3 summarizes reported formaldehyde measurements in schools, which were found in the scientific literature, which we reviewed. There were two papers and one EPA report which reported formaldehyde measurements in U.S. schools. Black and Worthan (1995) reported formaldehyde measurements made in a complaint school after mitigation. The average concentrations in this school were $0.01 \mathrm{ppm}$ before and during occupancy. This is below the $0.05 \mathrm{ppm}$ concentration value that is considered acceptable. Sheldon et al. (1989 a, b) measured a number of indoor air pollutants, including 
formaldehyde, in several public buildings, including a non-complaint primary school in Washington, D.C. Formaldehyde samples were collected on molecular sieve for 30-minute periods on three different days in four different sites within the school. Samples were analyzed using a colorimetric method with a lower limit of detection between 0.05 and $0.09 \mathrm{ppm}$. With the exception of one sample, for which a trace of formaldehyde was reported $(0.012 \mathrm{ppm})$, all samples were below the limits of detection.

Turk, et al. (1987a) reported formaldehyde measurements for 6 non-complaint schools in the Pacific Northwest. Samples were collected over a 10 day period and the limit of detection was $0.02 \mathrm{ppm}$. In general, the formaldehyde concentrations were below the $0.05 \mathrm{ppm}$ guideline. A high value of 0.192 ppm was measured in the cafeteria of one school during the summer, with no obvious source. Based upon retesting, it was concluded that this result should be viewed as a transient event not representative of the building.

Average formaldehyde concentrations reported for 10 schools in Milan, Italy (Cavallo, et al., 1993) and 10 schools in Paris, France (Laurent, et al., 1993) were also generally at or near the $0.05 \mathrm{ppm}$ limit of acceptability. However, for both sets of European schools, some of the formaldehyde concentrations were sufficiently high that irritant symptoms might very well have been experienced by the occupants of some school classrooms.

Olsen and Dossing (1982) reported measurements of formaldehyde made in 10 day care centers in Denmark. Seven of the daycare centers were located in mobile buildings and 3 were in permanent buildings. Samples collected with sodium bisulfite solution and analyzed with chromotropic acid method. The average formaldehyde concentration for the mobile buildings was $0.35 \mathrm{ppm}$ (range: 0.20 $0.45 \mathrm{ppm}$ ), approximately five times higher than the average of $0.065 \mathrm{ppm}$ for day care centers in permanent buildings. Mucous membrane irritation of eyes, nose and throat were three times more frequent among the staff in the mobile buildings than the permanent buildings.

The ICF Kaiser report (1994), which reviewed 23 U.S. school IAQ studies (most were not published studies in the scientific literature), reported that formaldehyde measurements were conducted in 11 of the 23 school IAQ studies it examined. The results included concentrations up to $2.9 \mathrm{ppm}$, which appears to be an error (see Bryant, et al., 1989).

\subsubsection{California School Indoor Air Quality Investigations}

Seventeen of the California schools investigations included formaldehyde measurements. These measurements were generally made using either the NIOSH impinger method or Drager Gas Detector Tubes. These reports have been summarized in Table 7.4, identified by the date of the report. All of these reports were done in response to some type of complaint regarding the school or classroom. Of the 57 measurements made using a method with a detection limit below $0.2 \mathrm{ppm}$, only 4 were above 0.05 ppm and none was above $0.1 \mathrm{ppm}$.

The remaining measurements were all below the $0.2 \mathrm{ppm}$ detection limit of the method used. Although these data cannot be considered a random sample, they do suggest that formaldehyde concentrations in California classrooms, including portables, are probably generally low. However, it should be noted that in those instances in which outdoor air was measured, the indoor levels were all somewhat greater than those outdoors. 
Table 7.3. Concentrations of Formaldehyde Measured in School Classrooms and Reported in the Published Scientific Literature

\begin{tabular}{l} 
Study Description \\
\hline Black, and Worthan, 1995. Measurements \\
made in an LAQ complaint school in \\
Washington state after mitigation. Sampling \\
and analysis method not described.
\end{tabular}

Cavallo, et al., 1993. Measurements in 10 schools in Milan, Italy. Samples collected with DNPH-amberlite tubes for 5 hours. Analyzed by high pressure liquid chromatography/diode array detection.

Laurent, et al., 1993. Measurements made in 10 schools in Paris. One week samples collected with passive samplers with DNPHzoated glass fiber filters; analyzed by high pressure liquid chromatography/ultraviolet detection.

Olsen and Dossing, 1982. Measurements made in 10 day care centers, 7 located in mobile buildings and 3 in conventional buildings in Denmark. Samples collected with sodium bisulfite solution and analyzed with chromotropic acid method.

Sheldon, et al., 1988. Measurements of formaldehyde made in four locations in a Washington, D.C. school on 3 days at each site. Samples collected on molecular sieve and analyzed using colorimetry.

Turk, et al, 1987a. Measurements made in 6 schools, 2 in Portland, OR and 4 in Spokane. Schools ranged from $3-25$ years in age, $1-3$ stories; all had mechanical ventilation systems of some type. Samples collected for 10 days with a passive formaldehyde sampler.

\begin{tabular}{|c|c|c|}
\hline & \multicolumn{2}{|c|}{ Formaldehyde, ppm } \\
\hline & Average: & Range: \\
\hline Before occupancy: & 0.01 & $<0.005-0.023$ \\
\hline After occupancy: & 0.01 & $<0.005-0.017$ \\
\hline & Average: & Range: \\
\hline $\begin{array}{l}\text { Nurseries \& } \\
\text { kindergartens: }\end{array}$ & 0.065 & $0.008-.137$ \\
\hline $\begin{array}{l}\text { Primary \& } \\
\text { secondary: }\end{array}$ & 0.067 & $0.006-0.171$ \\
\hline $\begin{array}{l}\text { Primary and nursery } \\
\text { schools }\end{array}$ & $\begin{array}{c}\text { Average: } \\
0.049\end{array}$ & $\begin{array}{c}\text { Range: } \\
0.005-0.218\end{array}$ \\
\hline & Average: & Range: \\
\hline Mobile Bldgs.: & 0.35 & $0.20-0.45$ \\
\hline Permanent Bldgs. & 0.065 & $0.04-0.09$ \\
\hline Primary school & $\frac{\text { Average: }}{\text { BDL }}$ & \\
\hline & Average: & Range: \\
\hline Bldg. 1, Portland & 0.034 & $0.024-0.053$ \\
\hline Bldg. 2, Portland & $\mathrm{BDL}^{\mathrm{b}}$ & $0.010-0.036$ \\
\hline Bldg. 16, Spokane & 0.020 & BDL - 0.034 \\
\hline Bidg. 17, Spokane & BDL & BDL \\
\hline Bldg. 20, Spokane & 0.042 & BDL -0.192 \\
\hline Bldg. 29, Spokane & BDL & $\mathrm{BDL}$ \\
\hline
\end{tabular}

a. $\mathrm{BDL}=$ below detection limit; limit of detection estimated from data presented to be $0.002 \mathrm{ppm}$

b. Limit of detection for the method was $0.02 \mathrm{ppm}$ 
Table 7.3. Concentrations of Formaldehyde Measured in School Classrooms and Reported in the Published Scientific Literature (continued)

\begin{tabular}{l} 
Date $^{\text {a }}$ and Description \\
\hline December, 1987. Classroom module \\
November, 1988. Measurements made in four
\end{tabular}

modular classrooms

February, 1989. Samples collected in a complaint classroom

April, 1990. Samples collected around lids of biology specimen containers

September, 1990 a. Measurements made due to concerns about pesticide use

September, 1990 b. Measurements made in a portable classroom and outdoor air

February, 1991. Measurements made in a school office, at air supply and outdoor air.

May, 1991. 24-hour sample collected in a classroom in an elementary school

December, 1991. Samples collected in two classrooms in a pre-fabricated modular classroom unit in November and December

February, 1992. Duplicate measurements made in 6 portable classrooms
Method; LOD
Formaldehyde, ppm
Drager Gas Detector Tube;
LOD: $0.02 \mathrm{ppm}$
Classroom: $<0.2$
Outside: $<0.2$

NIOSH impinger method ${ }^{b}$; ' S1: $\quad 0.015$

LOD: Not reported ${ }^{\mathrm{c}} \quad$ S2: 0.018

Outside air: $<0.05$

Drager Direct-Reading

Tubes;

LOD not reported

Evidence of leakage of formaldehyde from containers reported

NIOSH impinger method ${ }^{\text {b. }}$; LOD: Not reported ${ }^{\text {c. }}$

Classroom: $\quad 0.02$

Multi-purpose room : 0.02

Outdoor air: 0.004

NIOSH impinger method ${ }^{c}$;

LOD: $0.008 \mathrm{ppm}$

Method unspecified;

Reported LOD: 0.01 ppm

DNPH method ${ }^{\mathrm{d}}$.

LOD: 0.0005

Drager Direct Reading

Indicator Tubes;

LOD: Not reported

NIOSH impinger method ${ }^{c}$., LOD: Not reported
Site A: $\quad 0.042$

Site B: $\quad 0.059$

Outdoor air: $<0.008$

Office: $<0.01 \mathrm{ppm}$

Classroom: 0.039

P-9: 0.018 (Nov); 0.073 (Dec)

P-10: 0.015 (Nov); 0.034 (Dec)

Outdoor Air: 0.005 (Dec.)

G1: $0.022,0.035$

G2: $0.026,0.025$

G3: $0.039,0.039$

G4: $0.022,0.022$

G5: $\quad--, 0.035$

G6: $\quad 0.03,0.02$

Outdoor Air: < 0.01

a. Reports and schools are identified only by the date of the report.

b. $L O D=$ Limit of detection

c. Samples collected in $1 \%$ solution of sodium bisulfite; chromatropic acid colorimetric analysis. The limit of detection for the NIOSH impinger method depends upon the volume of air sampled.

d. DNPH method: samples are collected on a C-18 cartridge with dinitrophenylhydrazine reagent and are analyzed by high pressure liquid chromatography with ultraviolet detection 
Table 7.4. Summary of Reported Formaldehyde Measurements in California Schools

\begin{tabular}{|c|c|c|}
\hline Date $^{2 .}$ and Description & Method; LOD ${ }^{6}$ & Formaldehyde, ppm \\
\hline $\begin{array}{l}\text { March, 1993. Measurements made in one } \\
\text { school office }\end{array}$ & Drager detection tubes & $\begin{array}{l}1:<0.2 \\
2:<0.2\end{array}$ \\
\hline $\begin{array}{l}\text { April, } 1994 \text {. Measurements in } 2 \text { classrooms, } \\
\text { principal's office, reception and outdoors }\end{array}$ & $\begin{array}{l}\text { Drager Direct-Reading } \\
\text { Indicator Tubes, } 0.04 \text { ppm }\end{array}$ & All measurements: $<0.04$ \\
\hline $\begin{array}{l}\text { June, 1994. Comparison of air quality in } 2 \\
\text { classrooms, one in a portable and one in a } \\
\text { permanent school building. }\end{array}$ & $\begin{array}{l}\text { Drager Direct Reading } \\
\text { Indicator Tubes; } \\
\text { LOD: } 0.04 \mathrm{ppm}\end{array}$ & $\begin{array}{l}\text { Portable: } \quad<0.04 \\
\text { Permanent: }<0.04\end{array}$ \\
\hline $\begin{array}{l}\text { September, } 1994 \text {. Duplicate measurements } \\
\text { made in } 2 \text { portable classrooms }\end{array}$ & $\begin{array}{l}\text { Drager Gas Detector Tube; } \\
\text { LOD: } 0.02 \mathrm{ppm}\end{array}$ & $\begin{array}{l}\mathrm{U} 1:<0.02,<0.02 \\
\mathrm{U} 10:<0.02,<0.02\end{array}$ \\
\hline $\begin{array}{l}\text { December, } 1994 \text {. Samples collected in } 23 \\
\text { rooms in School No. 1, one sample in School } \\
\text { No. } 2\end{array}$ & $\begin{array}{l}\text { Colorimetric method used } \\
\text { but not specified; } \\
\text { LOD: } 0.02 \mathrm{ppm}\end{array}$ & $\begin{array}{l}\text { School 1: } 18 \text { samples }-<0.02 \\
2 \text { samples }>0.05 \\
\text { Maximium: } 0.08 \\
\text { School } 2:<0.02\end{array}$ \\
\hline June, 1996. Sample collected in one classroom & $\begin{array}{l}\text { Drager Direct Reading } \\
\text { Indicator Tubes; } \\
\text { LOD: } 0.04 \mathrm{ppm}\end{array}$ & Room 9: $<0.04 \mathrm{ppm}$ \\
\hline
\end{tabular}

a. Reports and schools are identified only by the date of the report.

b. $L O D=$ Limit of detection

\subsection{Microbiological Contaminants}

\subsubsection{Definitions}

The term "microbiological contaminants" refers to a diverse variety of microbiological agents that have been found in indoor environments and can cause human diseases and adverse health effects. Airborne microbiological agents are commonly termed bioaerosols. The major classes of microbiological pollutants of concern in indoor air are: (1) viruses, bacteria, endotoxins from bacteria; (2) allergens, including house dust mite allergens [(Dermatophagoides pteronyssinus allergen I (Der $\mathrm{p}$ I) and Dermatophagoides farinae allergen I (Der $f \mathrm{I}$ )], and allergens from animal dander [e.g., Felis dosmeticus allergen I (Fel d I)]; and (3) fungi.

Airborne viruses and bacteria can cause infectious diseases such as influenza, tuberculosis, Legionnaires diseases, etc. There is evidence that low ventilation rates and other building characteristics can lead to increased incidence of respiratory diseases caused by viruses (Brundage, et al., 1988). No references were found to viral measurements in schools, probably because airborne viruses are very difficult to measure. Total bacteria, however, have been measured in schools in a number of studies. The major indoor source of most bacteria is building occupants, e.g., measles, tuberculosis. The bacteria responsible for Legionnaires' disease and Pontiac fever, however, are from environmental sources, e.g., cooling towers, evaporative condensers, whirlpool baths and shower heads (Macher, et al., 1992). 
Bacterial endotoxins, composed of lipopolysaccharide from the outer membrane of Gramnegative bacteria, have also been found in house dust and airborne particulate matter in homes (Berrens, 1970; Michel, et al., 1989; Rylander, et al., 1989). Effects of inhalation exposure to endotoxins include fever, cough, diffuse aches, shortness of breath, itchy eyes, nausea and fatigue, as well as acute air flow obstruction (Rylander, et al. 1989; 1992). Bacterial endotoxins, however, have been measured infrequently and we did not find any references to measurements in schools.

House dust mite allergens are among the most potent allergens found in buildings, and exposures to house dust mite allergens can cause asthma and trigger asthma attacks in sensitized subjects (Samet, et al., 1988). House dust mites thrive under conditions of high relative humidities and allergies to house dust mite allergens are more frequent in marine west coast, Mediterranean and tropical climates where mild humid winters provide optimum conditions for mite growth (Reed and Swanson, 1986). Cat and dog allergens found in house dust can also cause symptoms in a significant fraction of allergic subjects. For example, Warner (1992) noted that, in the United Kingdom, approximately $80 \%$ of allergic asthmatic children are allergic to house dust mite allergen, while up to $40 \%$ are sensitized to cat and/or dog allergen. These allergens can be carried into schools on the clothing of children and staff who have pets at home.

Exposures to mold spores in indoor air can also cause allergic reactions in sensitized subjects, with symptoms such as runny nose, watery eyes, cough, sneezing, and fevers. Water damage in a building, from leaky roofs or flooding, often leads to the growth of molds and to airborne exposures to mold spores from various genera such as Aspergillus, Alternaria, Cladosporium, etc.

Many of the microbiological pollutants are found in dust deposited on surfaces, e.g., allergens from house dust mites or animal dander, and are suspended into air by intermittent activities that stir up dust such as walking or vacuuming. Molds are also found on indoor surfaces arid can release spores into the indoor air. Once deposited on floors and other surfaces, the spores can be resuspended. Because releases of these bioaerosols into air can often be very intermittent, short-term air sampling is not always successful in detecting these materials. Furthermore, the commonly used air sampling methods for many of the bioaerosols are usually limited to less than 15 minutes sampling time. For these reasons, microbiological contaminants in indoor environments are often characterized by collecting surfaces dusts or molds for analysis or by visual inspection for the presence of mold.

\subsubsection{NIOSH School HHERs}

Bioaerosol sampling was conducted in eight of 77 NIOSH school HHERs. Measured air concentrations were very low. However, a number of NIOSH investigators noted that mold was visible although no air measurements were reported or they were less than the lower limit of detection (Blade, 1992; Kiefer, et al., 1993). However, as noted by Berardinelli (1992), “ . . NIOSH generally does not routinely recommend (airborne bioaerosol monitoring). However, visible microbial growth on interior building surfaces, for example, should serve as clear evidence that there is a potential biological problem and steps should be taken to correction conditions supporting such growth. It is not typically necessary, or helpful, to then try to quantify this contamination. The guidelines published by the American Conference of Governmental Industrial Hygienists' Committee on Bioaerosols share this interpretation, "One should use air sampling as a last resort ....... Air sampling rarely provides proof of inappropriate exposure to bioaerosols." (ACGIH, 1995). 


\subsubsection{Publications in Scientific Journals and Conference Proceedings.}

Total Airborne Bacteria. Table 7.5 summarizes in school measurements of total airborne bacteria reported in scientific journals and conference proceedings. These values do not include any breakdown by bacterial species, although in some cases, there was some species identification. The reported measurements range over two orders of magnitude, from $7 \mathrm{CFU} / \mathrm{m}^{3}$ to as high as 19,500 $\mathrm{CFU} / \mathrm{m}^{3}$. Occupant density as well as ventilation rate are strong determinants of total levels of airborne bacteria. However, occupancy and ventilation rates have not been reported in these studies.

Air quality standards have not yet been developed for airborne microbes, although Morey (1984) has suggested that microbial concentrations in excess of $1000 \mathrm{CFU} / \mathrm{m}^{3}$ indicate possible microbial contamination and warrant further investigation. This may not be an appropriate standard for California, however, where an average of $1403 \mathrm{CFU} / \mathrm{m}^{3}$ has been reported for total bacteria in outdoor air (Gallup, et ai., 1993).

Bates and Mahaffy (1996) reported levels of airborne bacteria in 2 schools in Florida. School 1 was a complaint school and measurements made in three complaint classrooms ranged from 60 to 270 $\mathrm{CFU} / \mathrm{m}^{3}$. Airborne bacteria measured in a second school in a classroom with complaints was reported to be $1,050 \mathrm{CFU} / \mathrm{m}^{3}$. The latter room was a science room with a strong musty odor and mold growth on three ceiling tiles suggesting that mold rather than bacteria was the cause of the complaints. Black and Worthan (1995) reported measurements of total bacteria for a school in Washington state which had been mitigated for indoor air quality problems. Measurements were made before and after the schools was reoccupied. The total bacteria level was higher when the building was occupied, as would be expected. Measurements of airborne bacteria reported by Cousins and Collet (1989) for 3 schools in Alberta, Canada were similar to the values reported by Black and Worthan.

The most extensive set of measurements of airborne bacteria has been reported by Gallup, et al. (1993) for 150 classrooms in 40 schools in California. Most of the samples were collected from ongoing field work in response to complaint situations, although none was reported to have had microbiological problems. Concentrations were higher in classrooms occupied by students than in offices and working areas, which have a lower occupancies. The average reported for occupied classrooms was 2,345 $\mathrm{CFU} / \mathrm{m}^{3}$, with a maximum of $18,432 \mathrm{CFU} / \mathrm{m}^{3}$. The average for unoccupied classrooms was similar to that reported for offices and working areas. The mean bacterial count of 55 associated outdoor samples collected near these schools was $1403 \mathrm{CFU} / \mathrm{m}^{3}$, with a range of 70 to $16,949 \mathrm{CFU} / \mathrm{m}^{3}$.

These investigators also reported measurements made in 326 California offices and working areas in 73 multistoried buildings and in 23 rooms in 8 California homes. The average concentration for the offices was $124 \mathrm{CFU} / \mathrm{m}^{3}$ (range 12 to $1201 \mathrm{CFU} / \mathrm{m}^{3}$ ). Mean outdoor concentration for 90 samples collected near the office buildings was $596 \mathrm{CFU} / \mathrm{m}^{3}$ (range: $70-3314 \mathrm{CFU} / \mathrm{m}^{3}$ ). For the 8 homes, the average was $655 \mathrm{CFU} / \mathrm{m}^{3}$ with a range of 24 to $18,432 \mathrm{CFU} / \mathrm{m}^{3}$. 
Table 7.5. Measurements of Airborne Bacterial Counts in Schools Reported in the Published Scientific Literature

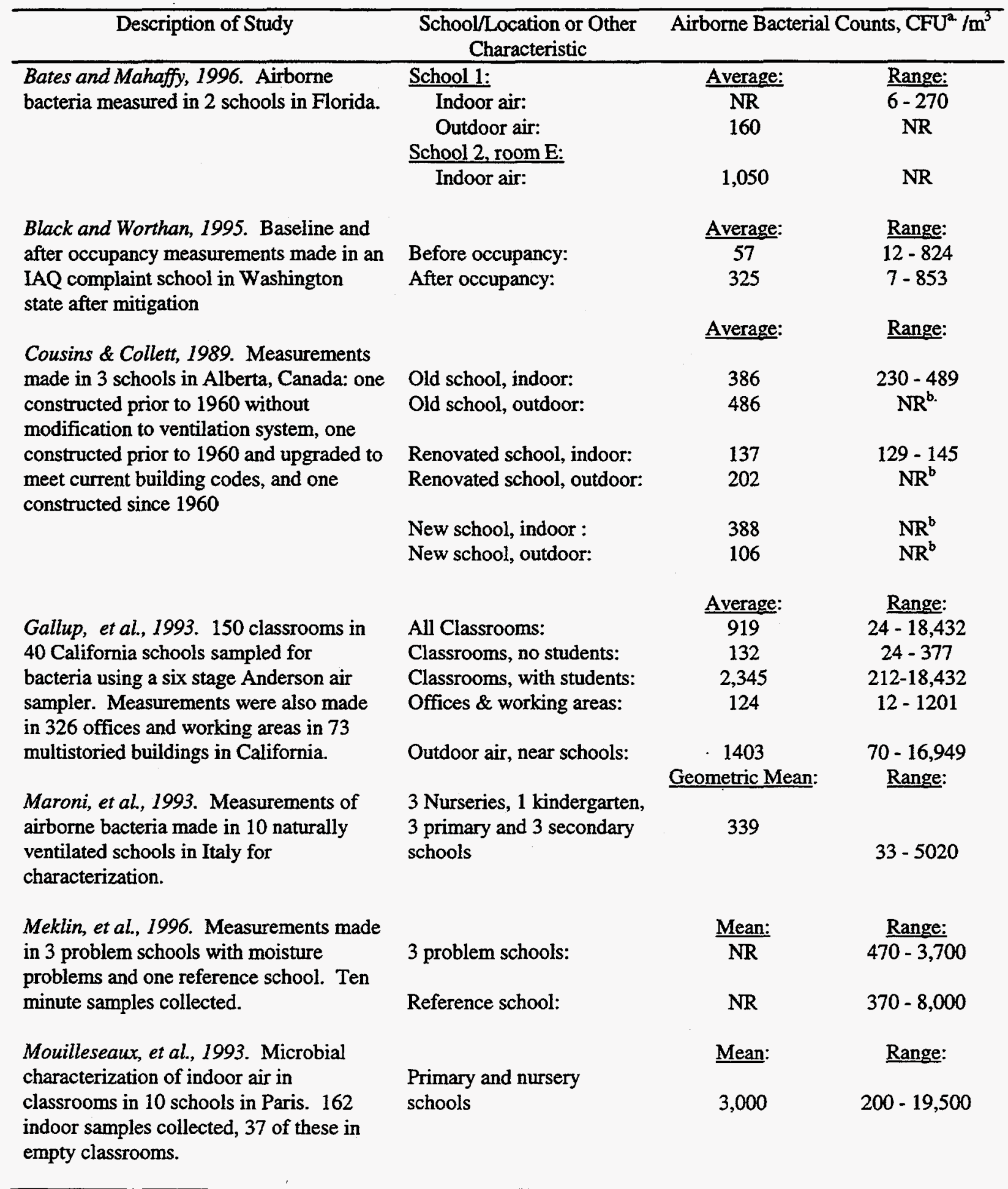

a. $\mathrm{CFU}=$ colony forming units

b. $\mathrm{NR}=$ not reported 
Table 7.5. Measurements of Airborne Bacterial Counts in Schools Reported in the Published Scientific Literature (continued)

\begin{tabular}{|c|c|c|c|}
\hline Description of Study & $\begin{array}{l}\text { School/Location or Other } \\
\text { Characteristic }\end{array}$ & \multicolumn{2}{|c|}{$\begin{array}{l}\text { Airborne Bacterial Counts, } \\
\qquad \mathrm{CFU}^{2} / \mathrm{m}^{3}\end{array}$} \\
\hline $\begin{array}{l}\text { Thorne, 1993. Measurements made in } \\
\text { problem school (U.S.) with odor complaints. } \\
\text { Addition of commercial bacillus product to } \\
\text { sump to eliminate odors resulted in } \\
\text { dispersion of bioaerosols into classrooms. }\end{array}$ & $\begin{array}{l}\text { Location: } \\
\text { Sump Room } \\
\text { Gymnasium } \\
\text { Classroom A } \\
\text { Classroom B }\end{array}$ & $\begin{array}{c}\text { Before } \\
\text { Mitigation: } \\
761 \\
665 \\
212 \\
106\end{array}$ & $\begin{array}{l}\text { After } \\
\text { Mitigation: } \\
\text { c. } \\
\text { c. } \\
\text { c. } \\
\text { c. }\end{array}$ \\
\hline
\end{tabular}

a. CFU $=$ colony forming units

b. $\mathrm{NR}=$ not reported

c. Reported only as a percent of outdoor levels. No value reported for outdoor levels.

The most commonly observed bacteria among all these buildings, when identifications were made, were Micrococcus and Bacillus species and pigmented gram negative rods such as Flavobacterium species, and coryneforms. Gallup, et al. noted that increased counts of "normal" bacteria were observed with increased dust levels and increased activity, as well as higher numbers of building occupants.

Meklin, et al. (1996) recently reported measurements of airborne bacteria in 3 problem schools with moisture problems and one reference school in Finland. The total concentration of airborne bacteria was significantly higher $(\mathrm{p}<0.01)$ in the reference school than in school \#2 or school \#3. These investigators noted that the range of concentrations found in the 3 problem schools $\left(470\right.$ to $\left.3,900 \mathrm{CFU} / \mathrm{m}^{3}\right)$ were similar to those reported for normal houses.

Thorne (1993) reported measurements made in a U.S. school with an odor problem from a sump. Treatment of the sump with a bacterial preparation resulted in dispersion of a bacterial bioaerosol due to unbalanced pressures in the school, which had not been corrected. The highest concentrations of bacteria were measured in the sump room and the adjacent gymnasium.

The measurements made in classrooms in 10 naturally ventilated schools in Italy (Maroni, et al., 1993) and in 10 primary schools in Paris (Mouilleseaux, et al., 1993) generally overlap the range of values which have been reported for U.S. and Canadian schools. Maroni, et al. (1993) reported that the principal species found in the Italian classroom were Staphylococcus (85\% of samples), Micrococcus ( $72 \%$ of samples) and Difteroides (70\% of samples). Mouilleseux, et al. reported that $32.7 \%$ of their samples contained Staphylococcus aurus, 6.2\% contained Enterobacteria, including Escherichia coli, and $50.6 \%$ contained Streptococcus D.

Allergens. There have been few measurements of allergens such as Dermatophagoides pteronyssinus allergen $I$ (Der $p ~ D$ ) from dust mites, Felis dosmeticus allergen $I$ (Fel d I) from cats or Canis familiaris I (Can $\mathrm{f} I$ ) from dogs in schools, although there are good reasons to suspect that these may be significant to the health of children in classrooms. Exposures to these allergens can cause asthma and trigger asthma attacks in sensitized subjects (Samet, et al., 1988). The California coastal region has a climate which is favorable to growth of dust mites in indoor environments. Cat and dog allergens can be carried on the clothes of children and teachers and shed in classrooms (Dybendal and Elsayed, 1989; Munir, et al., 1993), accumulating to levels which may cause symptoms in children with asthma who are sensitized to these allergens. 
Verhoeff, et al., (1994) have stated that concentrations of more than 2,000 ng Der p I per gram of dust are regarded as representing a risk for development of specific IgE to house dust mite allergen in genetically predisposed individuals. Levels higher than $10,000 \mathrm{ng}$ Der $\mathrm{p}$ I per gram of dust are supposed to increase the risk for acute attacks of asthma. According to Platts-Mills, et al. (1995), concentrations above $10,000 \mathrm{ng}$ of cat or dog allergen per gram of dust are sufficient to cause sensitization and associated risk of asthma in exposed children. For comparisons between rooms, the dust per unit area should also be taken into account.

Table 7.6 summarizes the data reported for measurements of allergens in dusts collected from carpeted or smooth floors in schools. Bates and Mahaffy (1996) reported measurements of allergens in carpet dusts collected from 13 classrooms in 6 Florida schools before and after cleaning. Samples of carpet dust were collected from 7 classrooms with health complaints (indicated in Table 7.6 with an asterisk) of headaches, stuffed sinuses, sore throats, respiratory illnesses, lethargy, itchy eyes and runny noses and from 6 classrooms without complaints. All of the classrooms had level loop pile carpet on the floors. Der $\mathrm{p} I$ and Der $\mathrm{f} I$ were measured and the sum of both reported; Der $\mathrm{p}$ I was reported as the dominant species in all carpet dust samples. Before the carpets were cleaned, 5 of the classrooms had levels of house dust mite allergen plus cat allergen above $2,000 \mathrm{ng} / \mathrm{g}$ of dust. Two of the rooms had levels above $9,000 \mathrm{ng} / \mathrm{g}$. Although only the sums of the two allergens are reported, the levels of allergens in the dusts in these latter two rooms might cause problems in sensitive occupants. The average concentration of mite allergens per gram of carpet dust was $4957 \pm 4963$ (S.D.) $\mathrm{ng} / \mathrm{g}$ for the 7 complaint rooms compared to $211 \pm 205$ (S.D.) $\mathrm{ng} / \mathrm{g}$ for the 6 non-complaint rooms. With one exception, all of the dust mite concentrations measured for the complaint rooms were greater than $948 \mathrm{ng} / \mathrm{g}$. The highest concentration for the non-complaint rooms was $663 \mathrm{ng} / \mathrm{g}$. After cleaning, the levels of mite allergen were substantially reduced.

Air samples were also collected for 8 hours per day but all were below the limit of detection. The authors were did not state whether the air samples were collected while the rooms were occupied or unoccupied. If they were unoccupied, than low air levels would be expected.

Dybendal and Elsayed (1992) sampled dust in 60 classrooms in 10 Norwegian schools and analyzed the floor dust for major cat and house dust mite allergens: Fel d I, Der p I and Der $\mathrm{f}$ I. Fel d I (feline allergen) was detected in all classrooms and ranged from 40 to $1100 \mathrm{ng} / \mathrm{gram}$ of dust (12 to $16,840 \mathrm{ng} / \mathrm{m}^{2}$ floor area). The mean Fel $\mathrm{d}$ I concentration was about 11 times higher per $\mathrm{m}^{2}$ for carpeted floors compared to smooth floors for a 10 day sampling period. Der $\mathrm{p} I$ and Der $\mathrm{f} I$ were detected in very low concentrations $\left(<1-104 \mathrm{ng} / \mathrm{m}^{2}\right.$ floor area). A significantly higher content of allergens per gram of dust was also found for carpeted than smooth floors, as measured by basophil histamine release. In an earlier paper, Dybendal, et al. (1989) reported finding higher contents of cat, dog, hen egg white, cod fish, mold and timothy pollen allergens dusts from classrooms with carpet compared with dusts from classrooms with smooth floors. 
Table 7.6. Measurements of Allergens in Dusts Collected in Schools and Reported in the Published Scientific Literature

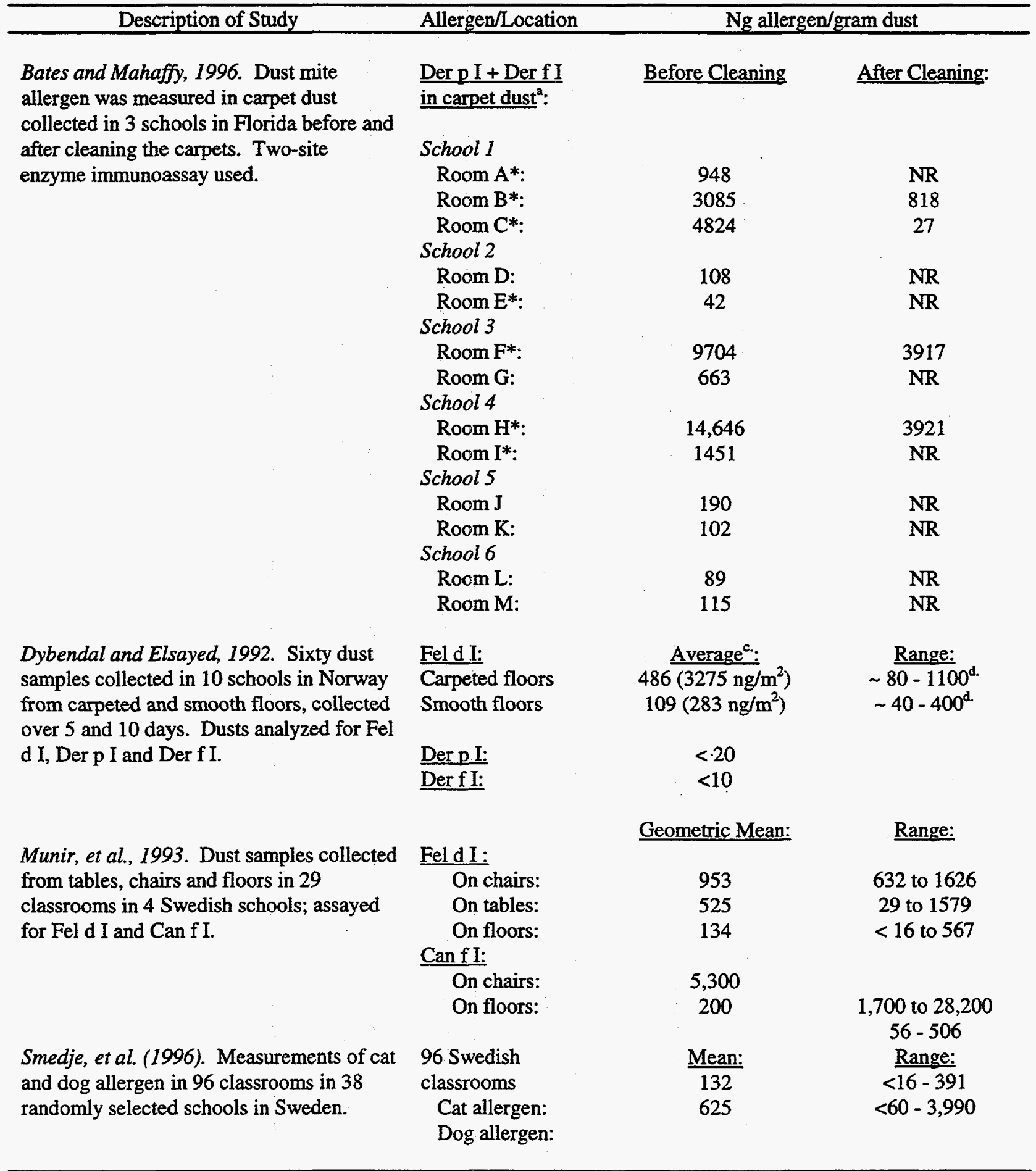

a. Der $\mathbf{p}$ I (house dust mite allergen) reported as the dominant allergen measured in all samples.

b. $\mathrm{NR}=$ not reported. It is not clear from the authors' table whether the blank indicates "not measured" or "below the limit of detection."

c. Average for samples collected over 10 days with new model vacuum cleaner.

d. Estimated from Figure 2.

* = Complaint classroom 
Munir, et al. (1993) collected dust samples from tables, chairs and floors in 29 classrooms in 4 Swedish schools and assayed the dust for cat and dog allergens, Fel $\mathrm{d} I$ and Can $\mathrm{f} I$. Higher amounts of Fel d I were found on chairs $(953 \mathrm{ng} / \mathrm{g})$ than on tables $(525 \mathrm{ng} / \mathrm{g})$ or floors $(134 \mathrm{ng} / \mathrm{g})$. The concentrations of Can $f I$ were higher than those of Fel $\mathrm{d} I$ in the dusts from both the chairs and the floors. The concentrations of Can $f$ I on chairs was within the range previously found by other investigators for houses with dogs. The authors conclude that the levels of these two major allergens are probably high enough to sensitize children and to induce asthma in most children who are allergic to cats or dogs.

Smedje, et al. (1996) has recently reported measurements of cat and dog allergen in 96 classrooms in 38 randomly selected schools in Sweden. The methods used for sampling and analyses were not reported in this short paper. However, these investigators reported that cat allergen in dust averaged $132 \mathrm{ng} / \mathrm{gram}$ of fine dust while dog allergen averaged $625 \mathrm{ng} / \mathrm{gram}$ of fine dust. The maximum concentration reported was $3,900 \mathrm{ng}$ dog allergen/gram of fine dust.

Fungi. Rao, et al. (1996) have recently reviewed existing quantitative standards and guidelines for fungi in indoor air. They report that existing standards are based primarily on baseline data rather than health effects data. They are either absolute (numerical) or relative (indoor outdoor comparisons) or a combination of the two. Quantitative standards/guidelines range from less than $100 \mathrm{CFU} / \mathrm{m}^{3}$ to greater than $1000 \mathrm{CFU} / \mathrm{m}^{3}$ (total fungi) as the upper limit for non-contaminated indoor environments. For total viable fungi, governmental and private organizations seem to generally agree that levels above about 750 - $1000 \mathrm{CFU} / \mathrm{m}^{3}$ are cause for concern and investigation. In addition, there seems to be a general agreement that toxigenic and pathogenic fungi are not acceptable in indoor air. Limitations in the standards and guidelines include reliance on short-term grab samples analyzed only by culture, lack of standardized protocols for data collection, analysis and interpretation, and the lack of connection to human dose-response data. In addition, since toxin concentrations in spores is most likely independent of viability, measurements of culturable fungi may not adequately reflect the potential for health problems.

Table 7.7 summarizes measurements of total airborne fungi measured in schools in the U.S. and Canada. Bates and Mahaffy (1996) investigated airborne and surface fungi in 13 classrooms in 6 Florida schools. Florida is a state with a very humid climate and widespread reports of allergy symptoms from students and staff in schools. In each school, 4-minute samples were collected in 2 typical classrooms. All of the classrooms were carpeted. Classrooms with health complaints are indicated in Table 7.7 with an asterisk. Health complaints included stuffed sinuses, sore throats, respiratory illnesses, lethargy, itchy eyes and runny noses. Concentrations above $1,000 \mathrm{CFU} / \mathrm{m}^{3}$ were measured in one complaint classroom and one non-complaint room. Concentrations measured in the other classrooms were all below 700 $\mathrm{CFU} / \mathrm{m}^{3}$. Concentrations of viable fungi were generally higher in outdoor than indoor air for these schools. However, three of the schools had visible mold growth on ceiling tiles and musty odors in some rooms. Health complaints occurred in rooms with a relative humidity over $69 \%$.

Bayer et al. (1995) reported measurements of viable fungi in 3 elementary schools in Georgia with complaints of rashes and respiratory illness. Measurements were made in 2 complaint classrooms and 1 or 2 non-complaint classrooms in each school. Concentrations were higher in the complaint than non-complaint rooms in these 3 schools. The dominant species identified was Cladosporium herbarum. In each school, fungal contamination was evident both on surfaces and in the air.

Black and Worthan (1995) reported measurements made in a complaint school in Washington state. However, their measurements were all made after mitigation measures. Measurements made before and after re-occupancy were all below $800 \mathrm{CFU} / \mathrm{m}^{3}$. Cousins and Collett (1989) reported measurements of fungi in 3 Canadian schools - one old, one renovated, and one new school. Indoor concentrations of fungi were all very low in these schools. 
Table 7.7. Measurements of Airborne Fungi in U.S. and Canadian Schools Which Have Been Reported in the Published Scientific Literature

\begin{tabular}{|c|c|c|c|}
\hline Description of Study & School/Location & \multicolumn{2}{|c|}{$\mathrm{CFU} / \mathrm{m}^{3 \mathrm{a}}$} \\
\hline \multirow{4}{*}{$\begin{array}{l}\text { Bates and Mahaffy, 1996. Airborne fungi } \\
\text { measured in } 6 \text { schools in Florida and in outdoor } \\
\text { air. Samples collected for } 4 \text { minutes. }\end{array}$} & & Inside Air: & Outside Air: \\
\hline & School \# 1: & & \multirow{4}{*}{1,185} \\
\hline & Room A* & 140 & \\
\hline & Room B* & 200 & \\
\hline & Room C8 & 90 & \\
\hline & School \# 2: & & \multirow{4}{*}{790} \\
\hline & Room D & 70 & \\
\hline & Room E* & 2,400 & \\
\hline & School \# 3: & & \\
\hline & Room F* & 120 & \multirow[t]{2}{*}{340} \\
\hline & Room G & 330 & \\
\hline & School \# 4: & & \multirow{3}{*}{2,800} \\
\hline & Room $H^{*}$ & 120 & \\
\hline & Room I* & 30 & \\
\hline & School \# 5: & & \multirow{3}{*}{2,100} \\
\hline & Room J & 1,500 & \\
\hline & Room K & 630 & \\
\hline & School \# 6: & & \multirow{3}{*}{4,900} \\
\hline & Room L & 340 & \\
\hline & Room $\mathbf{M}$ & 200 & \\
\hline \multirow{8}{*}{$\begin{array}{l}\text { Bayer, et al., } 1995 . \text { Investigations of } 3 \\
\text { elementary schools in Georgia. Samples } \\
\text { collected for } 1-5 \text { minutes in each classroom. }\end{array}$} & School No. 1: & & \\
\hline & 2 complaint classrooms: & $567 ; 861$ & \\
\hline & $\begin{array}{l}2 \text { noncomplaint } \\
\text { classrooms: }\end{array}$ & $154 ; 35$ & \\
\hline & School No. 2: & $630 ; 490$ & \\
\hline & $\begin{array}{l}2 \text { complaint classrooms: } \\
1 \text { noncomplaint } \\
\text { classroom: }\end{array}$ & 140 & \\
\hline & & $280 ; 1470$ & \\
\hline & School No. 3: & $105 ; 35$ & \\
\hline & $\begin{array}{l}2 \text { complaint classrooms: } \\
2 \text { noncomplaint } \\
\text { classrooms: }\end{array}$ & & \\
\hline \multirow{4}{*}{$\begin{array}{l}\text { Black and Worthan, } 1995 . \text { Measurements } \\
\text { made in an IAQ complaint school in } \\
\text { Washington state after mitigation, before and } \\
\text { after occupancy. }\end{array}$} & & Average: & Range: \\
\hline & Before occupancy: & 300 & $47-777$ \\
\hline & After occupancy: & 214 & $35-707$ \\
\hline & & Average: & Range: \\
\hline $\begin{array}{l}\text { Cousins \& Collett, 1989. Measurements made } \\
\text { in } 3 \text { schools in Alberta, Canada; one }\end{array}$ & Old school: & 175 & $89-269$ \\
\hline constructed prior to 1960 without modification & Renovated school: & 98 & $55-141$ \\
\hline to ventilation system, one constructed prior to & New school: & 56 & \\
\hline $\begin{array}{l}1960 \text { and one upgraded to meet current } \\
\text { building codes, and constructed since } 1960 \text {. }\end{array}$ & & & \\
\hline
\end{tabular}

a. $\mathrm{CFU}=$ Total colony forming units of culturable fungi 
Shaughnessy, et al. (1993) reported large reductions of bioaerosols in non-mechanically ventilated New Mexico school classrooms with improved filtered ventilation. Burkhard Personal Volumetric Samplers for total spores in the air as well as Andersen Samplers for viable spores were used for sampling as well as an experimental carpet sampling procedure for fungi and bacteria. Even though there are no standard protocols for taking and interpreting carpet sampling for fungi and bacteria, the authors concluded that the samples suggest that the carpets may be considered unsanitary. Indoor to outdoor viable and total spores ratios range from 1.8 to 46 . Two sites showed high concentrations of viable spores indicating bioaerosol contamination. Penicillium and Aspergillus were cultured from indoor air (as well as carpet) sources while none were detected outdoors. It appeared that a heat recovery ventilator with $30 \%$ dust spot efficiency filters contributed to decreased bioaerosol levels.

The ICF Kaiser review (1994), which included many unpublished reports of school investigations, reported that biological contamination was a significant finding in 6 of 23 school IAQ studies (23\%) examined. Data reported from Ellringer (1995) suggest that NIOSH HHERs, at least for office buildings, may under-represent the scale of bioaerosol problems in complaint buildings. For example, compared to the 5 percent of 450 NIOSH sick building syndrome investigations where bioaerosols were identified as a major concern, bioaerosols were identified as major concern in 34 percent of 147 State of Minnesota complaint buildings).

Measurements of airborne molds made in European schools are summarized in Table 7.8. Dotterud, et al. (1996) reported measurements of viable molds made in Northern Norway homes and classrooms of 19 children sensitized to house dust mites and of 19 non-atopic control children. Average airborne concentrations of viable molds were very low for both sets of 7 classrooms. The authors note that the classrooms were uncarpeted, very clean and had low relative humidity.

Indoor concentrations of total airborne fungi made in 10 non-complaint Italian schools (Maroni, et al., 1993) and in 10 non-complaint primary and nursery schools in Paris (Mouilleseaux, et al., 1993) were all quite low. Even the concentrations of total fungi in 3 problem and 1 reference school in the Netherlands (Meklin, et al., 1996) were generally low. Concentrations in only one of three complaint schools were higher than in the reference school. However, as noted above, air sampling may underestimate actual exposures due to the very short sampling times.

In an investigation of the relationship of asthma to factors in the school environment, Smedje, et al. $(1996,1997)$ measured total viable molds in 96 classrooms in 38 (out of 130) randomly selected schools in Sweden. The average concentration reported for the 96 classrooms was $500 \mathrm{CFU} / \mathrm{m}^{3}$; the maximum concentration measured was very high, $4,500 \mathrm{CFU} / \mathrm{m}^{3}$. These investigators did not report how many of the classrooms had concentrations above $1,000 \mathrm{CFU} / \mathrm{m}^{3}$.

There was one other report of measurements of viable molds by Gravesen, et al. (1986). These investigators measured molds in dusts collected from 36 carpeted rooms and 13 non-carpeted rooms in 21 Danish schools. Air measurements were not made. Significantly higher $(p=0.002)$ colony counts of molds were found for dust from carpeted $(\sim 1900 \mathrm{CFU} / \mathrm{g}$. dust) than the bare floors ( $\sim 950 \mathrm{CFU} / \mathrm{g}$. dust). The most commonly observed microfungal genera were Penicillium, Fusarium, Alternaria and Cladosporium. 
Table 7.8. Measurements of Airborne Fungi in European Schools Which Have Been Reported in the Published Scientific Literature

\begin{tabular}{|c|c|c|c|}
\hline Description of Study & School/Location & \multicolumn{2}{|c|}{$\mathrm{CFU} / \mathrm{m}^{3 \mathrm{a}}$} \\
\hline $\begin{array}{l}\text { Dotterud, et al., } 1996 . \text { Measurements made in } \\
\text { Northern Norway homes and classrooms of } 19 \\
\text { children sensitized to house dust mites and } 19 \\
\text { non-atopic control children. Average } \\
\text { concentrations of viable molds in } 14 \\
\text { classrooms in } 7 \text { schools }\end{array}$ & $\begin{array}{l}\text { Classrooms of: } \\
\text { Sensitized children } \\
\text { Non-atopic children }\end{array}$ & $\begin{array}{l}\text { Average: } \\
\\
8.8 \\
6.2\end{array}$ & \\
\hline $\begin{array}{l}\text { Maroni, et al., } 1993 \text {. Measurements of } \\
\text { airborne fungi made in } 10 \text { naturally ventilated } \\
\text { schools in Italy for characterization. }\end{array}$ & $\begin{array}{l}3 \text { nurseries, } 1 \\
\text { kindergarten, } 3 \text { primary } \\
\text { and } 3 \text { secondary schools }\end{array}$ & $\frac{\text { Geometric Mean: }}{14}$ & Range: \\
\hline & & Geometric Mean: & Range: \\
\hline $\begin{array}{l}\text { Meklin, et al., 1996. Measurements of } \\
\text { airborne fungi made in } 3 \text { problem and } 1 \\
\text { reference school in the Netherlands. Samples } \\
\text { collected for } 15 \text { minutes. }\end{array}$ & $\begin{array}{l}\text { Reference School: } \\
\text { Problem Schools: } \\
\quad \# 1 \\
\quad \# 2 \\
\text { \#3 }\end{array}$ & $\begin{array}{c}53 \\
150 \\
53 \\
59\end{array}$ & $\begin{array}{l}21-160 \\
52-530 \\
21-140 \\
5-150\end{array}$ \\
\hline $\begin{array}{l}\text { Mouilleseaux, et al., 1993. Characterization } \\
\text { of indoor air in classrooms in } 10 \text { primary and } \\
\text { nursery schools in Paris. } 162 \text { indoor samples } \\
\text { collected, } 37 \text { of these in empty classrooms. }\end{array}$ & $\begin{array}{l}6 \text { nursery schools plus } 4 \\
\text { primary schools }\end{array}$ & $\frac{\text { Mean: }}{100}$ & $\begin{array}{l}\text { Range: } \\
15-230\end{array}$ \\
\hline $\begin{array}{l}\text { Smedje, et al., } 1996,1997 . \text { Measurements of } \\
\text { viable molds made in } 96 \text { classrooms in } 38 \\
\text { randomly selected schools in Sweden. }\end{array}$ & 96 classrooms & $\frac{\text { Mean: }}{500}$ & $\begin{array}{l}\text { Range: } \\
100-4,500\end{array}$ \\
\hline
\end{tabular}

\subsubsection{California School Indoor Air Quality Investigations}

In the California schools investigations, bioaerosol sampling was conducted in only three of the 61 cases and all three cases were carried out by environmental consultants and not local health departments. The indoor concentrations of mold spores were less than outdoors in the three California schools. In several school investigations, water damaged ceiling tiles and/or carpets were reported and, in a few instances, mold growth on indoor surfaces or sub-flooring was reported.

\subsection{Carbon Monoxide}

\subsubsection{Sources and Standards}

Carbon monoxide originates from incomplete combustion of carbonaceous fuels, e.g., gas, gasoline. In outdoor air, $\mathrm{CO}$ is regulated as a Criteria Air Pollutant for which the 8-hour standard is 9 ppm. Sources in non-residential indoor air include outdoor air, malfunctioning heating appliances, 
vehicle exhaust from attached garages or loading docks located near building air intakes. Upon inhalation, $\mathrm{CO}$ binds with hemoglobin in blood, displacing oxygen and reducing delivery of oxygen to the body. Acute exposures can lead to coma and death within minutes. Sub-acute exposures can cause headache and nausea.

\subsubsection{NIOSH School HHERs}

Carbon monoxide was measured in 12 of $77(16 \%)$ the NIOSH school HHERs and it was generally near or below the limit of detection. The one exception was a measurement of $55 \mathrm{ppm}$ above a metal mold furnace in a school shop (McCammon, 1990).

\subsubsection{Publications in Scientific Journals and Conference Proceedings}

In the broader literature, it appears that $\mathrm{CO}$ has not generally been found at concentrations of concern in schools. For example, ICF Kaiser (1994) reported that none of the CO measurements that were conducted in 14 of 23 reviewed school IAQ studies exceeded two ppm. Likewise, Shaughnessy, et al. (1993) found no detectable levels of carbon monoxide in four non-mechanically ventilated New Mexico schools with elevated radon. Turk, et al. (1987a) found CO eight hour averages ranged from less than two ppm in four Oregon and Washington State noncomplaint schools to four ppm in two other noncomplaint schools in those states. Also, Berk, et al. (1979) monitored indoor and outdoor carbon monoxide levels in a non-complaint San Francisco area high school at different ventilation rates and found the indoor/outdoor concentrations nearly equal at all ventilation rates. The concentrations were consistently in the two to eight ppm range. In a non-complaint Columbus, $\mathrm{OH}$ elementary school, Berk, et al. (1980) reported that indoor and outdoor carbon monoxide levels were nearly equal at different ventilation rates and generally ranged below $12 \mathrm{ppm}$. In one case, however, indoor carbon monoxide was reported at $25 \mathrm{ppm}$. No explanation was given for this high concentration.

\subsubsection{California School Indoor Air Quality Investigations}

In the California school reports, 3 of the $54(6 \%)$ presented $\mathrm{CO}$ measurements. One of the investigators reported $5 \mathrm{ppm}$ in a classroom that was not continuously ventilated as required by state regulation. The source of $\mathrm{CO}$ was not identified.

\subsection{Airborne Particulate Matter (PM)}

In outdoor air, concentrations of airborne particulate matter (PM) have been federally regulated since 1970 because of evidence of adverse respiratory health effects and excess deaths at high exposure levels. In more recent years, there have been a growing number of epidemiological studies which suggest that daily rates of respiratory illness and of mortality from respiratory and cardiovascular diseases increase in response to levels of airborne particulate matter (PM) pollution below the current National Ambient Air Quality Standard for PM (e.g., Schwartz, 1993; Dockery, et al., 1992; Lipfert and Wyzga, 1995). Infiltration of outdoor air is one of the sources of PM in indoor air. However, there are also indoor sources of PM, such as resuspended dusts, which can add to total PM exposures. Microbiological pollutants (see section 4 above) in such resuspended dusts may significantly contribute to acute health effects in exposed populations. 
Measurements of PM are generally made by collection on a filter, typically over periods of 8,12 or 24 hours, and weighing the collected mass. Concentrations are commonly reported as mass per cubic meter of air. PM can vary in both particle size distribution and chemical composition. PM samples are often collected with devices that exclude particles greater than a certain size, e.g., PM-10 refers to a sample in which particles less than or equal to 10 micron mass median aerodynamic diameter (MMAD) are collected. Total suspended particulate matter (TSP) refers to samples collected on an open face filter with no exclusion of large particles. Determinations of PM chemical composition and/or the presence of bioaerosols, which may be of interest with respect to adverse health effects, require further characterization. The California air quality standard for PM-10 in outdoor air is $30 \mu \mathrm{g} / \mathrm{m}^{3}$ (annual geometric mean) and $50 \mu \mathrm{g} / \mathrm{m}^{3}$ for 24 -hours.

In the published scientific literature, Turk, et al. $(1987 \mathrm{a}, \mathrm{b})$ reported indoor measurements of respirable suspended particulate matter (RSP) (particles less than or equal to $3.5 \mu \mathrm{m}$ MMAD) in six Oregon and Washington State non-complaint schools. Eight hour averages ranged from less than 11 to $40 \mu \mathrm{g} / \mathrm{m}^{3}$, with the four highest measurements of $73,105,113$, and $144 \mu \mathrm{g} / \mathrm{m}^{3}$ associated with smoking. In addition, Shaughnessy, et al. (1993) reported large reductions of suspended particulate matter (PM) in a non-mechanically ventilated New Mexico school classroom obtained by improved filtration of outside ventilation air. Particulate matter concentrations averaged $198.6 \mu \mathrm{g} / \mathrm{m}^{3}$ before mitigation to $72.6 \mu \mathrm{g} / \mathrm{m}^{3}$ after mitigation. However, all--post- as well as pre-mitigation- of the indoor measurements for PM-10 were greater than EPA's National Ambient Air Quality Standard annual arithmetic average of $50 \mu \mathrm{g} / \mathrm{m}^{3}$ and California's 24-hour average standard of $50 \mu \mathrm{g} / \mathrm{m}^{3}$. Peaks in indoor. PM-10 levels were observed when the HVAC system was turned off for repair and when children were dancing on carpeting, indicating the influence of resuspension of dusts. Furthermore, Hanssen (1993) reported that suspended respirable particles were about 40 percent greater in classrooms with carpeting compared to those without. However, no significant relationship was found between aerosol concentrations and mucous membrane complaints and there was little association between indoor environmental measurements and complaints. It was hypothesized that removal of fleecy items (wall to wall carpet) and dust deposits (open bookshelves and wall decorations) are equally important as ventilation to reduce school indoor air complaints.

Four of the California school investigations reported particle sampling. Two investigations reported indoor concentrations similar to that outdoors. Another reported that indoor concentrations were two to 17 times greater than outdoors indicating significant contributions from indoor sources of PM.

\subsection{Ozone and Related Photochemical Air Pollutants}

Ozone is largely an outdoor air pollutant formed by atmospheric photochemical reactions of NOx and hydrocarbons from combustion and other sources. Although ozone originates in outdoor air, infiltration and active ventilation with outdoor air bring ozone into indoor environments. Subsequent depositional losses to indoor surfaces reduce indoor concentrations of ozone to varying degrees. However, if the ventilation rate with outdoor air is very high, indoor concentrations can be very close to outdoor concentrations (Weschler, et al., 1989; Stock and Venso, 1993). Ozone is a strong irritant and high concentrations are common in outdoor air in many parts of California during late spring, summer and early fall. The air quality standard for ozone in outdoor air in California is 0.09 ppm (1-hour average). 
In addition to outdoor air, photocopiers and laser printers can be sources of ozone in indoor air if filters in these devices are defective, overloaded by heavy use, or are not properly installed and maintained. Consequently, measurements of ozone in schools were also considered in this review.

An important early comparison of outdoor and indoor air pollutants was reported by Thompson, et al. in 1973. This study included six schools in the Los Angeles area. The highest levels of indoor airborne particulate matter and ozone, compared to the outdoors, were in schools that had no filtered ventilation air. Ozone levels were 30 percent of that outdoors in mechanically air conditioned schools compared to 60 percent in a school without air conditioning and 70 percent in schools with evaporative coolers which increase the outdoor air ventilation rate. Peroxyacetyl nitrate (PAN), nitrogen dioxide $\left(\mathrm{NO}_{2}\right)$, nitrogen oxide $\left(\mathrm{NO}_{\mathrm{X}}\right)$, and carbon monoxide $(\mathrm{CO})$ levels in the schools were comparable to the outdoors.

Ozone was not measured in any of the NIOSH school HHERs nor was it reported in any of the more recently published scientific papers. However, $\mathrm{O}_{3}$ measurements were reported in three of the California school investigations. The measurement results in two of the investigations were less than the lower limit of detection. In the third case, the result was $0.7 \mathrm{ppm}$. The ambient one-hour outdoor air standard for $\mathrm{O}_{3}$ is $0.12 \mathrm{ppm}$. This case involved office worker complaints of headaches, sore throats, eye and respiratory irritation, and cough that coincided with the arrival of a new laser printer and that were resolved when the printer was relocated. The printer contains corona discharge wires that create ozone by ionizing the oxygen in the air. Ozone was measured 12 inches from the printer at 0.7 ppm (FDA prohibits certain devices that emit more than $0.05 \mathrm{ppm}$ in occupied enclosed spaces). The printer had a defective filter.

\subsection{Other Pollutants}

Hydrogen Sulfide $\left(\mathrm{H}_{2} \mathrm{~S}\right)$. Only two NIOSH school HHERs involved sampling for $\mathrm{H}_{2} \mathrm{~S}$. The first case was an investigation by Burkhart and Jennison (1993) of a West Virginia. elementary school that had a recurring sewer gas odor that was caused by an outdoor air intake sucking in gas from a nearby plumbing vent. The vent was elevated above the intake before the investigators sampled for $\mathrm{H}_{2} \mathrm{~S}$ and none was detected indoors. The second case, an investigation by Gorman (1988) did not detect $\mathrm{H}_{2} \mathrm{~S}$ because a leak in a sewer line under the school's basement had been repaired after the HHER request had been made but before the site evaluation was conducted. None of the peer-reviewed studies reported $\mathrm{H}_{2} \mathrm{~S}$ measurements and although a number of the California school investigations involved sewer gas complaints, none had reported $\mathrm{H}_{2} \mathrm{~S}$ measurements.

Pesticides. Pesticides were a concern in at least one NIOSH school HHER (Elliot and Baron, 1991) and in at least one of the California school investigations. The NIOSH investigation involved a West Virginia junior high school where air sampling for chlordane revealed concentrations 2 to 11 times greater than the National Research Council's recommended residential level of $5 \mu \mathrm{g} / \mathrm{m}^{3}$. Pesticides also were identified by ICF Kaiser (1994) as the cause of indoor air problems in about nine of $189(5 \%)$ schools with IAQ problems according to newspaper articles but in only one of $44(2 \%)$ of the studies reported in journals or periodicals. ICF stated, "It may be that the relatively higher reporting of pesticide problems in newspaper articles is an artifact of pesticide exposure being an acute problem for which an obvious source exists. It may be that IAQ investigators are unlikely to be called . . . when the source of 
irritation is obvious. The newspaper search therefore implies that misapplication of pesticides may be a more common problem than generally recognized by IAQ investigative professionals." The California case involved a school in the southern portion of the state where pyrethrum was found to be less than 105 $\mu \mathrm{g} / \mathrm{m}^{3}$ compared to the state OSHA PEL of $5000 \mu \mathrm{g} / \mathrm{m}^{3}$. The PEL, however, is for industrial workers. Appropriate standards for the protection of the general population, or for children, have not been developed

\subsection{Summary}

The most commonly measured air pollutants in schools, other than $\mathrm{CO}_{2}$, have been TVOC, formaldehyde, $\mathrm{CO}$ and microbiological pollutants. Even among problem schools, such measurements are not done in the majority of cases. For example, for the NIOSH HHERs, only 27 of the 77 investigations reported measurements of TVOC. Of these, many were below the limits of detection or were similar to typical indoor concentrations that have been reported in homes (Wallace, et al., 1991). In some complaint or problem schools, TVOC concentrations have been reported which are in the range in which SBS symptoms such as eye, nose, and throat irritancy and headaches might be expected (Molhave, 1990). For the HHERs, high TVOC concentrations were associated with high emission indoor sources such as liquid-based photocopiers, floor mastic and painting. Unfortunately, TVOC measurements have not generally been made at the same time as measurements of $\mathrm{CO}_{2}$ or ventilation rates. It is possible that levels of TVOC are elevated in some of the school classrooms with inadequate ventilation, simply because there are many indoor sources of these compounds (including humans) and levels tend to build up without adequate ventilation.

There have been many more measurements of formaldehyde than of TVOC made in schools, although, surprisingly, formaldehyde measurements were reported for only 15 of the 77 HHERs investigations. Of this set, less than $20 \%$ exceeded the California DHS recommended maximum of 0.05 ppm. For California schools, we obtained formaldehyde data from reports on indoor air investigations for 16 schools. All of the measurements for the California schools were made in response to a complaint. The California measurements included some made in portable buildings because these were suspected to have high levels. Even in these buildings, the formaldehyde concentrations were generally below 0.05 ppm. The measurements that have been reported for U.S. schools, including California complaint schools, suggest that formaldehyde is probably not a problem in the majority of classrooms. However, since formaldehyde is highly irritating, and the measurements have been quite limited, it would be wise to measure formaldehyde in cases where there are irritant complaints and/or any possibility of elevated concentrations, e.g., new portable classrooms and new furnishings. In such instances, sampling should be conducted over a period of 6-8 hours during periods of occupancy so that an adequate measure of exposure is obtained. The analysis method should be sufficiently sensitive so that concentrations near or at the $0.05 \mathrm{ppm}$ level and higher can be measured accurately and precisely. In addition, there is some evidence to suggest that higher molecular weight aldehydes, $n$-pentanal, $n$-hexanal, and $n$-heptanal, might be of concern. These odorous and irritating aldehydes have been measured at quite high concentrations in new, energy-efficient residential buildings (A. Hodgson, LBNL, personal communication). They are suspected to originate from new wood products used in construction and may also be found in new school building. 
Although there is reason to suspect that airborne microbiological pollutants may be a significant factor in causing adverse health effects often observed in complaint schools, the sampling and analysis methods which have been developed and used to date severely limit our ability to characterize exposures to these agents in a way that is useful for understanding cause and effect. Sampling methods for air are generally very short-term and the subsequent analysis methods are not sufficiently sensitive. Furthermore, since these agents are often deposited on indoor surfaces and only re-suspended in air when there are human activities within the rooms, it is essential to make measurements when the classrooms are occupied and when students enter and leave the rooms. Standards against which to assess measurements are not well developed with respect to dose and response.

Despite these limitations, the measurements that have been reported in the literature provide some valuable insights. In the case of airborne bacteria for which humans are a major indoor source, high levels are suggestive of high occupancies and inadequate ventilation. One of the largest databases of reported measurements is for 150 classrooms in 40 California schools with complaints (Gallup, et al., 1993). The average airborne bacterial count for these classrooms when occupied was $2,345 \mathrm{CFU} / \mathrm{m}^{3}$. This is twice the $1000 \mathrm{CFU} / \mathrm{m}^{3}$ level which Morey (1984) suggested as indicative of possible microbial contamination and warranting further investigation. At the upper end of the range, concentrations as high as $18,432 \mathrm{CFU} / \mathrm{m}^{3}$ were reported for these California schools. This information, taken in combination with the measurements of high $\mathrm{CO}_{2}$ concentrations in complaint and non-complaint schools suggests that a significant fraction of California schools may not have the ventilation rates needed to remove and dilute the indoor concentrations of airborne bacteria and viruses which can cause infectious diseases, e.g., influenza, colds, tuberculosis. This certainly warrants concern and further investigation.

The existing data which have been reported in the literature also indicate that there is a significant potential for exposures to allergens such as house dust mite, cat and dog allergens, and molds in re-suspended dusts from carpeted and uncarpeted floors and other surfaces in schools. The climate of coastal California is one in which house dust mites might be expected to flourish. Studies in European schools have shown that dust mite allergen and cat and dog allergens can be found in schools, the latter two brought in on the clothing of children and teachers who have pets. There is evidence to suggest that carpeted floors may be a greater reservoir for such allergens than uncarpeted floors. However, there is also evidence from the studies in Florida that good cleaning practices can substantially reduce levels of these allergens. Since approximately $5-10 \%$ of children are asthmatic and may be sensitive to one or more of these allergens, or to cockroach allergen, the presence of such allergens in school rooms could pose a significant health risk with respect to asthma attacks.

The literature also indicates that molds in schools can sometimes be a problem. The most serious problems seem to occur when there is water damage from leaks or flooding followed by growth of mold on growing on water-damaged materials. A significant fraction of the population is allergic to molds. In addition, some molds are highly toxigenic and, even when non-viable, may contain endotoxins which can cause serious health problems. The potential for exposure to molds is probably best assessed through examinations of buildings for evidence of mold growth rather than more costly but less effective air sampling.

The reported measurements of carbon monoxide in schools are very limited but suggest that the source of this pollutant in many schools is outdoor air. Measurements of other air pollutants in schools are much too limited to suggest that there are any patterns. 
Finally, the penetration of outdoor air pollutants, such as PM, into schools may also be important in areas with high outdoor air concentrations. The penetration of PM-2.5 into buildings, along with ventilation air, is typically quite high. Thus children attending schools near major freeways may be exposed to airborne particulate matter at levels similar to those outdoors. A recent report by Brunekreef, et al. (1997) raises concerns about the potential impact of outdoor airborne particulate matter ${ }^{3}$ in schools located near major highways. These investigators found decrements in the lung function of children living near and attending schools located near major highways in the Netherlands. They also reported that their analyses of respiratory symptom data showed that truck traffic density and black smoke concentrations were also associated with increased reporting of chronic respiratory symptoms.

\footnotetext{
${ }^{3}$ Airborne particulate matter from outdoor air is brought into buildings with ventilation air; typical penetration factors for PM2.5 are about 0.8 to 0.9 .
} 


\subsection{An Overview}

Ideally, every building investigation would identify a specific pollutant or physical agent causing the indoor environmental complaints or occupant health symptoms and would measure changes in air pollutant levels and in symptom prevalences as a consequence of some remediation. Typically, however, building investigations identify certain building characteristics or problems that are likely to be associated with the complaints or symptoms, correct these, and assume that the remediation will mitigate the symptoms. These building characteristics generally fall into three major categories, which are not mutually exclusive:

- Ventilation system-related problems

- Pollutant source-related problems

- Building or HVAC renovation-related problems.

For each category, there can be various root causes, such as: 1) site factors; 2) design-related causes; 3) construction-related; 4) occupancy- or operations-related; or 5) service- or maintenance-based.

Building-related causes of indoor air quality problems are often compound and inter-related. An example of this is reflected in a Midwest U.S. elementary school with health complaints from teachers and some students in three classrooms (Rhodes, et al., 1993). It was found that the case classrooms had dramatically higher microbiological counts, in comparison to three control classrooms. The high microbiological counts in the case classrooms appeared to be related to operation of the air handling unit (AHU) fan under conditions of high filter loading. Under these operating conditions, contaminants would be drawn from the crawl space through leaks in the return ducts and AHU and disseminated to the classrooms. In this example, the ventilation system itself is a source of pollutants. The authors identified three designs and one installation cause for the indoor air quality problems:

1. the AHU was located in the crawl space and inaccessible for maintenance (design);

2. the location of the AHU in the crawl space, which was contaminated, increased the probability of contaminant entry into the system, since ducts generally leak (design);

3. the location of the return air-exhaust air damper on the discharge side of the return-air exhaust fan was also an inappropriate design practice. When the system was in economizer mode (outdoor air used for cooling), exhaust air would be released directly into the crawl space causing turbulence that would aerosolize contaminants.

4. the substandard, but generally accepted, duct installation allowed for contamination to enter the system and be distributed to occupants. 
Forty-nine of 77 school HHERs listed one or more building characteristics suspected to be associated with the symptoms reported by occupants in complaint schools. These are summarized in Figure 8.1. The most common building factors suspected to be associated with indoor environmental complaints were related to the ventilation system, with insufficient outdoor air being supplied to the occupied space the most commonly cited problem (84\%). A number of other ventilation system-related problems were also cited frequently, e.g., inadequate source exhaust $(51 \%)$, poor distribution or balance, poor HVAC maintenance.

The second most commonly cited building factor was water leaks in the building shell (56\%). This factor is frequently associated with mold contamination and may be classified a pollutant sourcerelated building problem. The 28 remaining HHERs either listed no building factor or only listed a specific pollutant such as formaldehyde or PCBs.

A more detailed break-out of building factors cited by NIOSH and other investigators as relevant to the indoor air complaints or concerns is found in Appendix C. Other than "insufficient outdoor air to occupied spaces" and "poor air distribution," the cited building factors are grouped according to those that: 1) appear to be design-related; 2) are probably design- or construction-related; 3) appear to be construction- or service-related; and 4) those that are maintenance- or occupant-related. This grouping reflects the fact that it is often difficult to attribute the cause solely to design, construction, operation or maintenance. In addition, the causes are sometimes compound and inter-related.

Figure 8.1 Building Factors Associated with IAQ Problems, 49 NIOSH School Health Hazard Evaluation Reports, 1981 - 1994

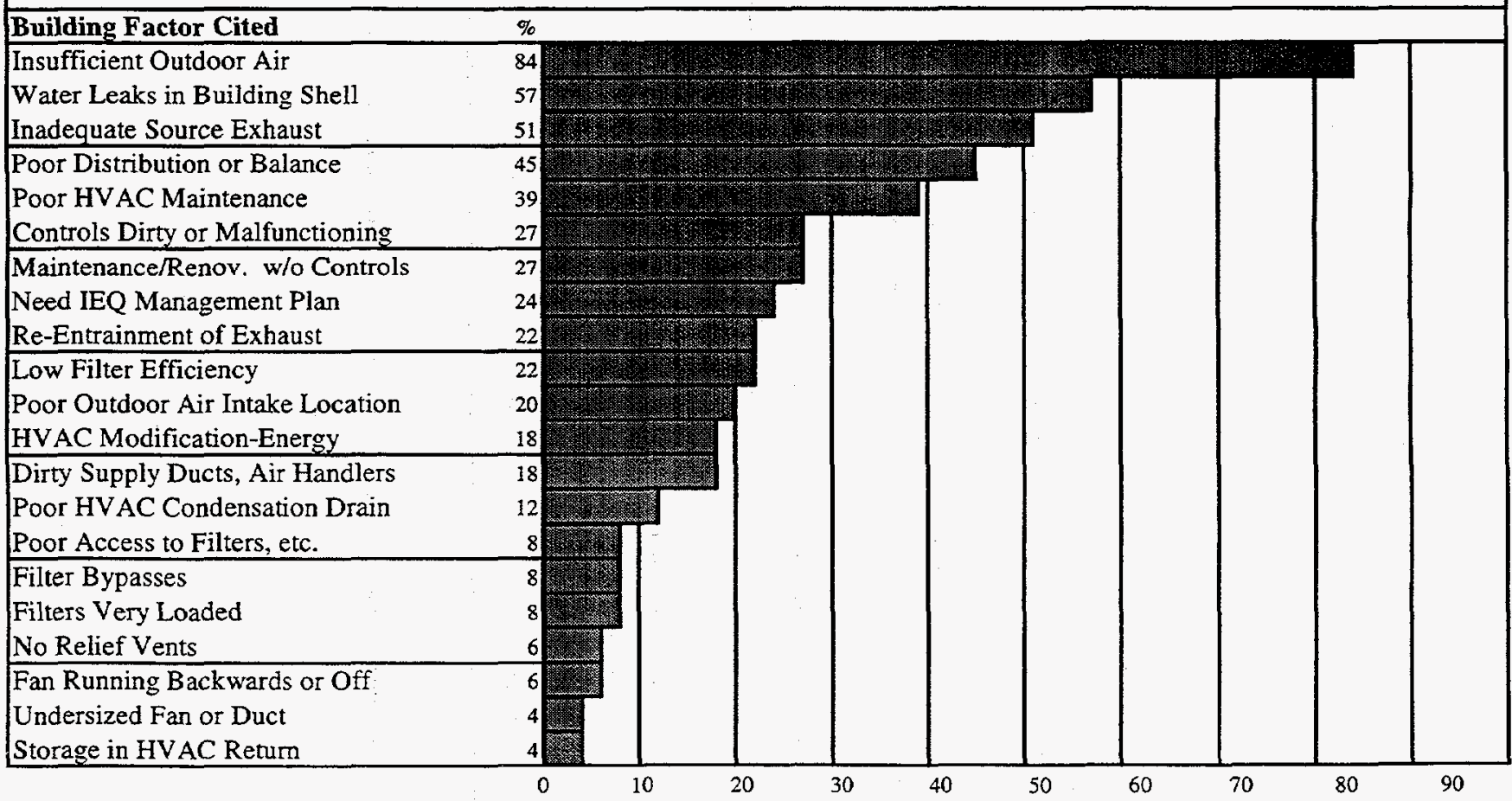


For the California complaint schools, 37 of the reports identified one or more building characteristics suspected to be associated with symptoms reported by occupants (see Figure 8.2). The most common building factor identified as a problem in the California schools investigations was insufficient outdoor air being supplied to the occupied space (84\%), as was found in the NIOSH HHERs. The second most common building factor cited was water leaks in building shells (22\%---much less than NIOSH's HHERs). Maintenance or other construction activity in occupied spaces without adequate control of pollutants (19\%) was the third most commonly cited building factor.

Ventilation system problems have also been commonly reported in scientific journals and proceedings of technical meetings. Fisher, et al. (1990), for example, reported ventilation system-related problems that range across the four broad categories listed above, in six New Mexico and Washington schools. All of the schools were found to have one or more HVAC problems: inoperative equipment (broken belts, fans, controls); poorly maintained equipment (disabled damper linkage, dampers painted shut); poorly designed equipment (ventilators too small or not used because of noise, controls in classroom); and unwitting modification of ventilation (replacing windows with insulated walls, sealed outdoor air intakes).

Figure 8.2 Building Factors Associated with IAQ Problems, 37 California School Investigative Reports, 1988 - 1996

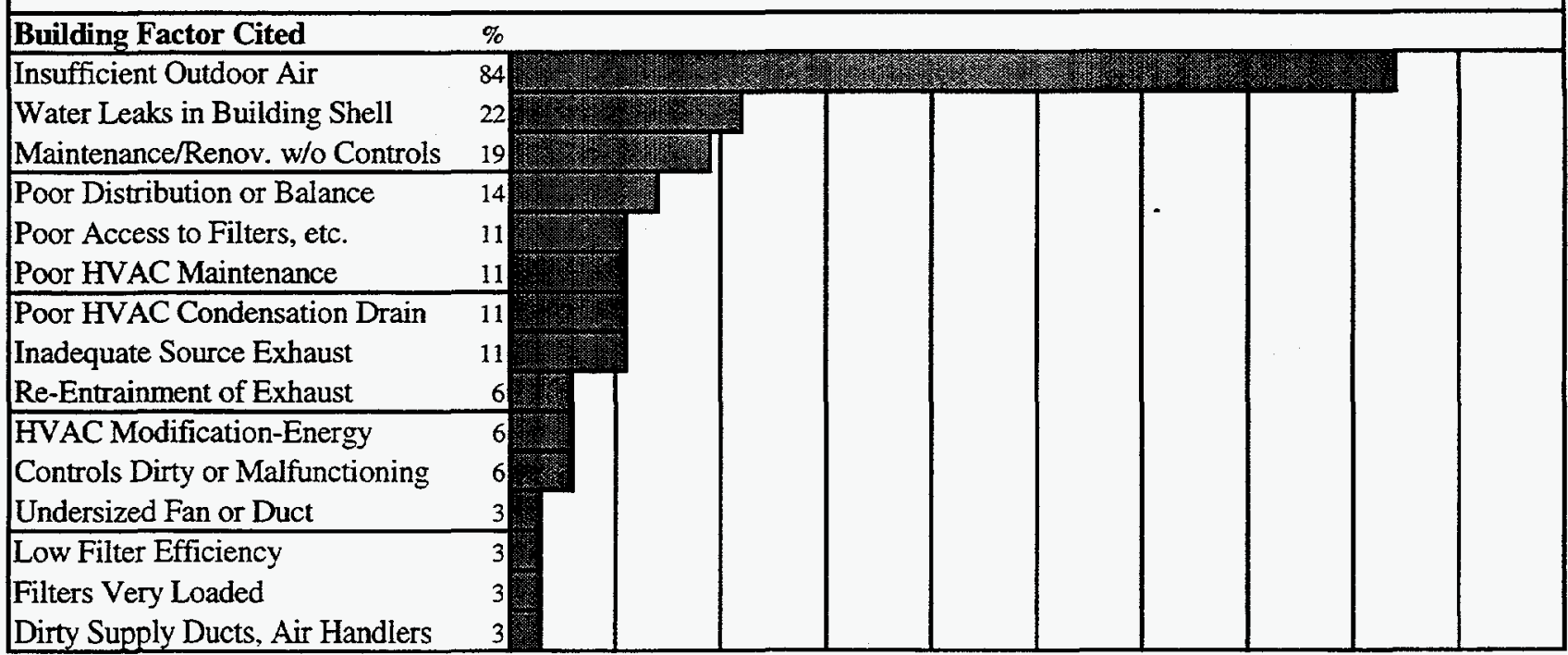

\subsection{Ventilation System-Related Building Problems}

\subsubsection{Insufficient Outside Air to Occupied Spaces}

Eighty-four percent of the HHERS reported insufficient outside air (OA) supplied to occupied spaces in the 49 complaint schools represented in Figure 8.1. Berardinelli (1994) reported $\mathrm{CO}_{2}$ levels as high as $4375 \mathrm{ppm}$ in one HHERs Blade (1992) reported a speech room and a counselor's office that depended on transfer air from adjacent rooms via the hall. Kiefer, et al. (1993) reported a problem 
school in which there were no OA supplies and the building was under negative pressure causing mold damage. Burkhart, et al. (1992) cited a ventilation system that would shut off OA if thermostats were mis-set. In the broader scientific literature, Chmelynski (1992) found that about $20 \%$ of U.S. schools HVAC systems are incapable of delivering conditioned OA to classrooms; Turner, et al. (1993) cited inaccessible, clogged insect screening and relief dampers.

HVAC controls were found to be a problem in 13 of 49 of the NIOSH school HHERs but in only two of $37(6 \%)$ California schools investigations. The NIOSH cases included thermostats that were broken or vandalized (Berardinelli, 1992); thermostats with dust accumulation and missing parts (Hanley, et al., 1991 \& 1992); and closed air dampers (Cantor and Lee, 1987). In a southern California school, a local health department investigator found that an economizer control malfunctioned and completely closed the outdoor air intake and thus, eliminated outdoor air for much of the time the ventilation system was operating.

California school investigators frequently found that ventilation would only be provided to classrooms and other occupied space when there was a call for heating or cooling. Furthermore, if the fan in the system could be operated manually to bring in ventilation air, it was often turned off because the noise of the fan made it difficult for the teacher and students to hear.

\subsubsection{Poor Distribution of Ventilation Air}

Poor distribution of ventilation air was reported in $45 \%$ of the 49 HHERs and $14 \%$ of the California IAQ investigations. Examples of poor air distribution or poor air balancing include: one classroom with $2000 \mathrm{ppm}$ of $\mathrm{CO}_{2}$ while the other classrooms had concentrations below $1000 \mathrm{ppm}$ (McCammon, 1990); a school originally built with open instructional areas that was altered with the installation of doors (Berardinelli, 1992); and controls improperly set with minimum supply air flows varied among classrooms (Hanley, et al., 1991, 1992).

\subsubsection{Poor Design of HVAC System}

In both the NIOSH HHERs and the California Schools Reports, problems due to poor design of HVAC systems were cited. Poorly located outside air intakes were reported in $20 \%$ of the HHERs. Six percent of the California schools investigations reported re-entrainment of exhaust air, suggesting that the air intakes and exhausts were not properly located with respect to each other. Poor access to filters in the HVAC system were reported in $8 \%$ of the HHERs and $11 \%$ of the California investigations. In some systems air dampers were not easily accessible for maintenance and indicators did not clearly show damper positions (Burr, et al., 1993). Hanley, et al. (1992) reported insulation on the outside of a main air handling unit (AHU) that blocked access to the coil, heat exchangers that were accessible only by leaning across pipes, access to filters blocked by pipes and ducts, and heat exchangers accessible for servicing only through removal of the entire fan assemblies. Undersized fans or ducts were identified in only one NIOSH (Cantor and Lee, 1987) and one California school investigation. In southern California, a local health department inspector found an undersized outdoor air intake on a portable classroom with poor classroom air quality. 
Some specific examples of poor outside air intake locations that contributed to school indoor environmental problems cited in NIOSH HHERs included: idling school bus diesel exhaust sucked into the schools' OA intakes (Hanley, et al., 1992); outside air intake for roof top air handling unit located near plumbing waste vents (Burr, et al., 1993); outside air intakes located next to a roof rubber membrane seam sealer which would emanate an odor as it heated up over the course of the day (Burkhart and Jennison, 1993); and outside air intake located next to an air conditioning cooling tower (Hanley, et al., 1991, 1992). In the broader literature, Environ (1994) reported that idling school bus diesel exhaust was sucked into a California school's outside air intakes.

Examples of re-entrainment or backdrafting problems reported in the school HHERs include: boiler exhaust stack located in close proximity to the outside air intake (Berardinelli, 1992); boiler exhaust sucked into six classrooms served by a hall exhaust fan (Gann and Schirmer, 1984); and boiler exhaust sucked via an underground utility tunnel through holes located beneath classrooms unit ventilators due to hallway exhaust fans (Gorman and Singal, 1984). In the broader literature, Turner, et al. (1993) found re-entrainment and backdrafting from some of the furnaces in a problem school.

\subsubsection{HVAC Operations-Related Ventilation Problems}

In some cases, the building and its HVAC system may be operated in a way that results in a ventilation problem although the system was properly designed and installed. For example, NIOSH investigator Donovan (1994) reported that a school's HVAC system was operated in the off mode for 10 minutes every half hour in order to save energy and thus, occupied classrooms and offices were denied any outdoor air one-third of the time. Kiefer, et al. (1993) reported a case in which the HVAC system was cycled off between 4:00 PM and 7:00 AM for energy conservation purposes in a windowless Florida elementary school with extensive mold contamination. In a school with formaldehyde concerns, static pressure reliefs that were clamped shut or heavily weighted shut have also been reported (Lee, 1986).

In the wider literature, during a period of time when ASHRAE 62 recommended as little as $5 \mathrm{cfm}$ of outdoor air per person in classrooms, Gardener (1985) listed some inexpensive energy conservation practices for schools including, "Cut back on outside air intake for ventilation." In a school with elevated indoor radon, Leovic, et al. (1991) found that outdoor air controls had been disconnected during the heating season to save energy. Also in the general literature, Andersson, et al. (1984) describe a kindergarten that had supply diffusers that caused discomfort due to drafts until one teacher found switches that controlled the ventilation system and subsequently switched off the fans. The investigators concluded that school ventilation systems must be properly designed or they will be disabled by occupants.

As previously noted, California school investigators often found that ventilation would only be provided to classrooms and other occupied space when there was a call for heating or cooling. Also, California investigators found that air handlers in portable classrooms were noisy and teachers would resist operating them even when carbon dioxide concentrations would reach $2850 \mathrm{ppm}$.

\subsubsection{Service-Related Causes of Inadequate Ventilation}

Assuming the original design and construction of the building and any subsequent additions and renovations were reasonable, the service provided to the building and its HVAC system may cause 
indoor air quality problems. Some of the service-related causes identified in school indoor air investigations were: fan running backwards or turned off; filter bypasses; and service-, maintenance-, or construction-related activities in occupied spaces.

Three NIOSH school HHERs but no California school investigations revealed ventilation problems associated with a fan running backwards or not operating at all. For a group of classrooms with carbon dioxide concentrations in excess of $2500 \mathrm{ppm}$, Burr, et al. (1993) found a fan inside a heat pump was running backwards. This problem was also reported for a New Mexico high school that was the subject of teacher complaints about inadequate ventilation. Daniels and Connon (1993) found a supply fan not operating. In a Massachusetts elementary school that had been the subject of five previous comprehensive environmental and ventilation assessments, Kaiser (1988a) found that motors in three of 13 roof-top air handlers were burned out.

\subsection{Pollutant Source-related Problems}

\subsubsection{The HVAC as a Source of Pollutants:}

In a substantial number of problem schools, poor HVAC maintenance led to contamination of the system and the HVAC system became a source of air pollution. Nineteen of the 49 (39\%) of the NIOSH school HHERs and 4 of 37 (11\%) California school investigations cited poor maintenance of the heating, ventilation and air condition system as a factor in indoor air quality problems. The NIOSH cases included: no HVAC maintenance for 15 years which resulted in dirty coils and microbial growth in all inspected air handling units in a windowless school (Donovan, 1994); filters on outside air intakes that were changed infrequently (McCammon, 1990); maintenance staff not trained on the proper operation of mechanical systems (Hanley, et al., 1991; 1992); and ". . One mechanic is responsible for maintaining and repairing all 114 heat pumps. This manpower level is inadequate to properly care for the HVAC system at the school. .." ( Burr, et al., 1993). Two California school reports cited poor HVAC maintenance in their investigations.

In nine of the 49 (18\%) NIOSH school HHERs---all since 1988--- and one of the 37 California school investigations, dirty supply ductwork or air handlers were cited as building-related factors suspected to be associated with indoor air quality problems. It is possible that earlier NIOSH school evaluations did not assess the interior of supply ductwork. NIOSH's cases included: Berardinelli (1994) who used a video endoscope and found all supply ducts in a West Virginia elementary school to be heavily loaded with dust and other debris; Salisbury and Scarf (1993) who found the inside of air handlers dusty, insect screens in need of cleaning, and dirty duct liners; and McCammon (1990) who found that rain and snow had been sucked into outdoor air intakes of a Wyoming junior high school and damaged the fiberglass duct lining to such an extent that in-line heating coils had been nearly blocked on at least two occasions. In addition, fiberglass dust was visually observed throughout the school.

In a southern California school with a history of health complaints associated with the building ventilation system, complaints continued even after a commercial duct cleaning firm cleaned the HVAC system. Eventually, the school district removed all fibrous duct lining and replaced the ducts. In the peer-reviewed, archival literature, Turner, et al. (1993) reported that complaint schools in two climatic zones in the U.S. had very large amounts of dust buildup in ducts. One school was only four years old. 
The NIOSH school HHERs reported a number of cases of poor drainage of HVAC condensation including: condensation drain lines that ran uphill (Hanley, et al., 1992); drains without vents and trap depth that did not exceed the suction pressure of the fan (Burr, et al., 1993); and roof top air handlers that drained condensation onto the roof top directly below OA intakes (Donovan, 1994). Two California school investigations found condensation drainage problems, including a condensation pan that was filled with muddy, stagnant, and foamy water; and condensation pans that were inaccessible and dirty.

Berardinelli (1994) is the only NIOSH school HHER investigator to note that air filters in ventilation systems were heavily loaded with dust. No California investigated reported dirty filters to be a problem. However, almost all California and NIOSH school on-site investigations occurred with the prior knowledge of school administrators and facilities staff and thus, it is possible that easy to correct deferred maintenance such as filter replacement may have taken place prior to the HVAC system evaluations. Eleven (22\%) of the NIOSH school HHERs but only one (3\%) of the California school investigations identified low air filter efficiency as a factor associated with indoor air problems. As reflected in Appendix C, nine of 28 NIOSH school HHERs since 1991 have recommended replacing filters with medium efficiency, pleated filters with efficiencies of at least 35 to $60 \%$ according to the dust spot test specified in ASHRAE Standard 52.1. Burkhart and Jennison (1993) as well as Hanley, et al. (1992) also emphasized that filters must be properly seated in the filter racks to prevent air from bypassing the filters.

Four NIOSH school HHERs, but no California school investigations, reported problems with air filter bypasses. Upon finding missing end caps on filter plenums in an Ohio school, NIOSH 's Burr, et al. (1993) noted that debris could build up on coils and become a substrate for bioaerosol growth as well as a nuisance when it dislodges and is blown through the occupied space. In another Ohio high school, Donovan (1994) conducted a HHER and found that filters had not been maintained for 16 years and the coils were dirty.

In the broader scientific literature, the importance of effective filtering of supply air is partially reflected in a study of airborne bacteria in six schools by Green, et al. (1985). They found that airborne bacteria in occupied classrooms in the winter were reduced 90 percent by ordinary filters.

Two NIOSH school HHERs but no California school investigations cited inappropriate storage in the building's HVAC system as a possible cause of indoor air complaints. In the clearest case, Berardinelli (1992) found that housekeeping and maintenance products were stored in the return air access area of the HVAC system in a West Virginia junior high school. In the case of a Florida elementary school, NIOSH investigator Decker (1993) found chemicals stored in a mechanical room.

\subsubsection{Water Leaks in the Building Shell}

Water leaks were reported in 28 of the $49(57 \%)$ NIOSH school evaluations and 8 of the 37 (22\%) of the California school investigations. The primary concern about water leaks is mold contamination. The differences in the prevalences of water leaks between the NIOSH schools HHERs and the California schools investigations may be climatic. The vast majority of the California school investigations originate from two counties in southern California whereas the majority of the NIOSH school investigations were from Ohio, Pennsylvania, and West Virginia. The NIOSH cases included: mold contamination of ceiling tile from a roof leak that occurred during reconstruction of the roof 
(Piacitelli, 1984); numerous roof leaks and broken, missing, and water-stained ceiling tiles that existed for five years and that were so severe that classes were canceled (Berardinelli, 1994); and mold and mildew associated with a chronically leaking roof in a windowless Florida elementary school (Kiefer, $e t$ al., 1993).

In a northern California elementary school, an environmental consultant found standing water under a portable classroom. In an adjacent community, the same consultant found that roof drains were connected to the crawlspace of an elementary school and thus, when it rained, the crawlspace would fill with standing water. In some areas, the floor insulation sagged and rested on the saturated soil. This school had been vacated due to unresolved indoor air concerns. In southern California, a health department inspector evaluated a carpeted school classroom that had been flooded due to surface run-off. The same investigator also inspected an elementary school where teachers complained about chronic respiratory problems and he found abandoned subslab ducts that were visibly damp from a roof leak.

In the peer-reviewed literature, Turner, et al. (1993) reported that complaint schools in two climatic zones in the U.S. had microbial contamination due to leaking roofs. One school was only four years old and had roof ice dam problems as well as burst pipes. The other was a 20 -year-old school that had defective roof drains.

\subsubsection{Inadequate Source Exhaust for Photocopiers, Kilns, and Other Special Sources}

Half of the NIOSH school HHERs that identified building factors as possible causes of indoor air quality problems cited inadequate spot exhaust of pollutant generating activities including: a householdtype bathroom exhaust fan that was the only means to vent combustion products when a kiln was fired and no exhaust ventilation for woodworking equipment in the industrial arts classroom (Berardinelli, 1992); no local exhaust ventilation for photocopiers that used liquid toner, a significant source of TVOCs (Burr, et al., 1993 and Anderson and Daniels, 1983); and an unvented flammable storage cabinet and the inappropriate use of particulate/charcoal filters ("Smoke-Eaters") instead of local exhausts for welding and a metal foundry furnace (McCammon, 1990).

California school investigations also found some cases of inadequate source exhaust, including : bathroom exhausts that were manually operated by occupants and when they were off and the HVAC system was on, the bathrooms became pressurized in respect to an adjacent office that reported a "rotten egg" odor; leaks in sewer lines that allowed sewer gas to infiltrate classrooms. In another case, a crawl space under a portable classroom was inadequately ventilated and the insulation in the crawl space to be littered with rodent droppings.

\subsubsection{Carpeting as a Source of Indoor Air Pollutants}

There is little mention of carpet associated with indoor environmental quality problems in the HHERs and California reports. NIOSH's Cantor and Lee (1987) recommended that carpet should be removed from areas where it is likely to be chronically exposed to stagnant water. Furthermore, carpet shampooing should not be done when the carpet will remain wet over long periods due to inadequate ventilation or lack of heat and chemicals should not be used as a long-term primary control strategy for control of mold. 
There are a number of papers in the peer-reviewed archival literature that identify an indoor air quality issue related to carpeting, e.g., emissions of volatile organic compounds, accumulation of allergenic bioaerosols. For example, Hansen, et al. (1987) reported that 579 Danish children with asthma in schools with carpet had an increased severity of asthma compared to children in schools with no carpet. This association was especially strong for the children who had no carpet in their rooms at home and had no pets. Also, Norback and Torgen (1987) compared questionnaire responses from (94\% response rate) 59 staff members in two Swedish schools with wall to wall carpeting and 133 staff members in four schools without carpeting and found a significantly higher frequency of health complaints in carpeted classrooms ( $p \leq 0.03$ ). Four years later, 37 of the 59 staff in the two carpeted schools with the carpet removed and 81 of the 133 staff in the four schools without carpeting were resurveyed and it was found that some of the health complaints remained significantly higher among those that previously had carpeting ( $\mathrm{p} \leq 0.02)$.

\subsection{Maintenance or Renovation Activities Without Sufficient Control of Generated Airborne Pollutants}

Thirteen of 49 (26\%) NIOSH school HHERs and seven of 47 (19\%) California school investigations reported indoor air quality problems associated with maintenance and replacement or other construction-related activity that was carried out without adequate control of pollutants that were generated by those activities. The NIOSH cases included: maintenance personnel that used a turpentine solution to clean carpet since it was effective in removing gum (Berardinelli, 1992); complaints about burning eyes, headaches, nausea, and respiratory problems following application of coal tar to the roof of an occupied school (Burkhart, et al., 1992); complaints in a windowless school where there was no provision to control contaminants from re-roofing from entering the building after which the filters in the HVAC systems were sprayed with a disinfecting deodorant that was not intended for such use (Kiefer, $e t$ al., 1993); and installation of new carpeting, gym floor resealing, and repainting that were related to occupant health symptoms that declined over time (Crandall and Wilcox, 1992)

NIOSH HHER investigator Kelly (1991 \& 1992) reported on two similar complicated cases involving Pennsylvania elementary schools where the solution to one problem became the cause of another. As part of asbestos abatement programs, vinyl floor tile were removed and then, an organic solvent was used to remove tile adhesive from the concrete floor slab. Following health complaints from occupants, school officials attempted unsuccessfully to mask the odor using deodorizers in one school. In the other, they used "bake-out" procedures as well as ion and ozone air purification systems and caulking of slab joints. Next, the carpet was removed from two of the classrooms and the concrete slab was treated with a sealant which provided short-term improvement. To avoid similar problems in the future, Kelly recommended: a plan to prevent elevated VOCs following mastic remover should be contractually specified; VOC monitoring by an independent consultant should be done before and after mastic remover use; the work area should be isolated from other areas and it should be mechanically exhaust ventilated; and with elevated VOC concentrations, the work area should be ventilated at a higher than normal rate.

In southern California, a health department investigator responded to teacher complaints about a chemical odor and found that a contractor had applied caulk to a roof-mounted air handler while the school was occupied and the air handlers were in operation. The caulk contained xylene, perchloroethylene, and propylene glycol methyl ether acetate. In another southern California school, a 
local health department investigator found that replacement of roofing, ceiling insulation, and ceiling tile generated an unusual white dust that caused headaches, burning eyes, upper respiratory irritation, and skin irritation among teachers. In another elementary school, the same investigator found aromatic petroleum distillate or high flash naphtha from liquid applied roofing had been drawn indoors through the outdoor air intakes of roof mounted air conditioners. It was recommended that future roofing work be done when the school was unoccupied. In another California case, a private cleaning company used a chemical agent to facilitate drying and inhibit microbial growth in a school classroom carpet that had been flooded. The classroom was then reoccupied and students began complaining about eye and throat irritation. A health department investigator noted that the chemical agent was recommended for use in well ventilated areas. 


\section{REFERENCES}

ALA. (1996) Making Schools "Lung Healthy," American Lung Association, New York, NY.

Almaguer, D., and Klein, M. (1991) NIOSH Health Hazard Evaluation Report: Northwest Vocational School, Cincinnati, OH, National Institute for Occupational Safety and Health, Cincinnati, OH, HETA 89-170-2100.

American Association of School Administrators (1983) The Maintenance Gap: Deferred Repair and Renovation in the Nation's Elementary and Secondary Schools. Arlington, VA, AASA, National Schools Board Association and Council of Great City Schools.

ACGIH. (1995) American Conference of Governmental Industrial Hygienists Bioaerosol Committee. Guidelines for the Assessment of Bioaerosols in the Indoor Environment. Cincinnati, OH, USA.

ACGIH. (1994) American Conference of Governmental Industrial Hygienists. (1994) 1994-1995, Threshold Limit Values for Chemical Substances and Physical Agents and Biological Exposures Indices. ACGIH, Cincinnati, $\mathrm{OH}$.

ASHRAE (1989) American Society for Heating, Refrigerating and Air Conditioning Engineers (1989) Ventilation for Acceptable Indoor Air Quality, Standard 62-1989, Atlanta, GA.

Anderson, K. and Daniels, W.J. (1983) NIOSH Health Hazard Evaluation Report: East Jackson Middle School, Jackson, Michigan, Cincinnati, $\mathrm{OH}$, National Institute for Occupational Safety and Health, HETA 82-335-1289.

Andersson, R., Boman, C.A. and Sandberg, M. (1984) Indoor climate problems in a kindergarten, and how they were solved, In: Indoor Air: Sensory and Hyperactivity Reactions to Sick Buildings, Berglund, B., Lindvall, T. and Sundell, J. (eds), Stockholm, Swedish Council for Building Research, 3: $335-340$.

Baird, J.C., Berglund, B., Berglund, U., Nicander-Bredberg, H., and Noma, E. (1987) Distinguishing between healthy and sick preschools by chemical classification, Environment International, 13: 167174.

Bates, J.M. and Mahaffy, D.J. (1996). Relationships of reported allergy symptoms, relative humidity and airborne biologicals in thirteen Florida classrooms. Proceedings of Indoor Air '96: The 7th International Conference on Indoor Air Quality and Climate, Nagoya, Japan, July, 1996, Vol. : 551556.

Bayer, C.W., Crow, S.A. and Noble, J.A. (1995) Production of volatile emissions by fungi. Proceedings, ASHRAE IAQ 95 Conference, pp. 101-110.

Bayer, C.W. and Downing, C.C. (1992) Indoor conditions in schools with insufficient humidity control. IAQ 92: Environments for People, Atlanta, GA, American Society of Heating, Air Conditioning, and Refrigerating Engineers, 197-200.

Berrens, L. (1970) The allergens in house dust. Progress in Allergy, 14: 259-339.

Berglund, B., Johansson, I., and Lindvall, T. (1982) A longitudinal study of air contaminants in a newly built preschool, Environment International, 8: 111-115.

Berglund, B., Berglund, U. and Lindvall, T. (1984) Characterization of indoor air quality and sick buildings, ASHRAE Transactions, 90 (1): 1045-1055.

Berardinelli, S. (1992) NIOSH Health Hazard Evaluation Report: South Junior High School, Morgantown, West Virginia, Cincinnati, OH, National Institute for Occupational Safety and Health, HETA 92-138-2258.

Berardinelli, S. (1994) NIOSH Health Hazard Evaluation Report: Kingwood Elementary School, Kingwood, West Virginia, Cincinnati, $\mathrm{OH}$, National Institute for Occupational Safety and Health, HETA 92-0362-2385.

Berk, J.V., Hollowell, C.D., Lin, C. and Turiel, I. (1979) The effects of energy efficient ventilation rates on indoor air quality at a California High School, Berkeley, CA, Lawrence Berkeley Laboratory, LBL-9174. 
Berk, J.V., Young, R., Hollowell, C.D., Turiel, I. and Pepper, J. (1980) The effects of energy-efficient ventilation rates on indoor air quality at an Ohio elementary school, Berkeley, CA, Lawrence Berkeley Laboratory, LBL-10223.

Bicknell, R.J. (1989) NIOSH Health Hazard Evaluation Report: Hudson Memorial School, Hudson, New Hampshire, Boston, MA, National Institute for Occupational Safety and Health, HETA 89-032.

Black, M.S. (1990). Indoor air quality in buildings and schools, Proceedings of the 77th Annual Meeting of the Association of Physical Plant Administrators of Universities and Colleges, Ottawa, Ontario, Canada, July 1-4, 1990 (APPAUC, Washington, D.C).

3lack, M.S., and A. Worthan. (1995) Development of a school reoccupancy plan following evacuation due to IAQ complaints - A case study. ASHRAE IAQ'95 Conference.

Blade, L.M. (1992) NIOSH Health Hazard Evaluation Report: J.M. Grasse Elementary School, Sellersville, Pennsylvania , Cincinnati, $\mathrm{OH}$, National Institute for Occupational Safety and Health, HETA 90-287-2250.

Blade, L.M. and Behrens, V.J. (1993) Health Hazard Evaluation Report: Rudd-Rockford-Marble Rock School, Rockford, Iowa, Cincinnati, OH, National Institute for Occupational Safety and Health, HETA 93-0341.

Bradstreet, W. (Unpublished) Draft report provided to W. Angell.

Brennan, T., Clarkin, M., Turner, W., Fisher, G. and Thompson, R. (1991a) School buildings with air exchange rates that do not meet minimum professional guidelines or codes and implications for radon control, ASHRAE IAQ 91 Healthy Buildings, Atlanta, GA, ASHRAE, 228-229.

Brennan, T., Fisher, E., Thompson, R. and Turner, W.A. (1991b) Extended heating, ventilation, and air conditioning diagnostics in schools in Maine, Proceedings of the 1991 International Symposium on Radon and Radon Reduction Technology, Washington, DC, U.S. EPA.

Brightman, H.S., Womble, S.E., Ronca, E.L. and Girman, J.R. (1996) Baseline information on indoor air quality in large buildings (BASE '95). Proceedings of the IAQ '96 Meeting, Vol. 3, pp. 1033-1038.

Brundage, J.F., Scott, R.M., Lednar, W.M., et al. (1988) Building-associated risk of febrile acute respiratory diseases in army trainees. J. Am. Med. Assoc., 259: 2108-2112.

Brunekreef, B., Janssen, N.A.H., de Hartog, J., Harssema, H., Knape, M., and van Vliet, P. (1997) Air pollution from truck traffic and lung function in children living near motorways. Epidem., 8 (3): 298303.

Bryant, C., O'Malley, M., Gorman, R. and Boiano, J. (1989) NIOSH Health Hazard Evaluation Report: Cincinnati Public Schools, Cincinnati, Ohio, Cincinnati, OH, National Institute for Occupational Safety and Health, HETA 86-421-1956.

Burkhart, J.E. and Jennison, E.A. (1993) NIOSH Health Hazard Evaluation Report: Blackshere Elementary School, Mannington, West Virginia, Cincinnati, $\mathrm{OH}$, National Institute for Occupational Safety and Health, HETA 93-0784-2350.

Burkhart, J.E., Short, S. and Knutti, E. (1992a) NIOSH Health Hazard Evaluation Report: Bethlehem Center Elementary School, Fredericktown, Pennsylvania, Cincinnati, OH, National Institute for Occupational Safety and Health, HETA 91-188-2205.

Burr, G.A. (1995) NIOSH Health Hazard Evaluation Report: Tri-County North School, Lewisburg, Ohio, Cincinnati, OH, National Institute for Occupational Safety and Health, HETA 95-0026-2488.

Burr, G.A. and Malkin, R. (1994) NIOSH Health Hazard Evaluation Report: Tri-County North School, Lewisburg, Ohio, Cincinnati, OH, National Institute for Occupational Safety and Health, HETA 940129-2397.

Burr, G.A., Wilcox, T.G., Klien, M.K., Weber, A.M. and Martinez, K.F. (1993) NIOSH Health Hazard Evaluation Report: Tri-County North School, Lewisburg, Ohio, Cincinnati, OH, National Institute for Occupational Safety and Health, HETA 93-011-2309.

Califomia Department of Education. (1995) Indoor Air Quality: A Guide for Educators, Sacramento, CA, School Facilities Planning Division. 
Canada Department of National Health and Welfare. (1987) Exposure Guidelines for Residential Indoor Air Quality. Ottawa.

Cantor, F.L. and Lee, S.A. (1987) NIOSH Health Hazard Evaluation Report: South Campbell County Middle School, Alexandria, Kentucky, Cincinnati, OH, National Institute for Occupational Safety and Health, HETA 86-073-1804.

Casey, M.E., Braganza, E.B., Shaughnessey, R.J. and Turk, B.H. (1995) Ventilation improvements in two elementary school classrooms, Proceedings, Engineering Solutions to Indoor Air Quality Problems Symposium, Pittsburgh, PA, Air and Waste Management Association.

Cavallo, D., D. Alcini, M. de Bortoli, D. Carrettoni, P. Carrer, M. Bersani and M. Maroni, (1993) Chemical contamination of indoor air in schools and office buildings in Milan, Italy. In: Proceedings of Indoor Air '93: The 6th International Conference on Indoor Air Quality and Climate, Vol. 2: 4549.

Centers for Disease Control and Prevention. (1991) Indoor Air Quality and Work Environment Symptoms Survey. Atlanta, GA, CDC.

Chmelynski, H. (1992) Characteristics of school buildings in the U.S., Proceedings of the 1992 International Symposium on Radon and Radon Reduction Technology, Washington, DC, U.S. EPA.

Cornwell, R. (1983) NIOSH Health Hazard Evaluation Report: Easton Elementary School, Morgantown, West Virginia, Cincinnati, OH, National Institute for Occupational Safety and Health, HETA 83-1761310.

Cousins, D.M. and Collett, C.W. (1989) Indoor air quality in 12 schools: A case study, ASHRAE Conference IAQ'87, The Human Equation: Health and Comfort, pp.104-108.

Crandall, M.S. (1986) Correspondence to H.T. Flaherty, Robert A. Taft High School, Cincinnati, Ohio, Cincinnati, OH, National Institute for Occupational Safety and Health, HETA 86-113, February 18.

Crandall, M.S. and Galson, S.K. (1987) NIOSH Health Hazard Evaluation Report: E.M. Crouthamel Elementary School, Souderton, Pennsylvania, Cincinnati, OH, National Institute for Occupational Safety and Health, HETA 86-535-1797.

Crandall, M.S. and Wilcox, T.G. (1992) NIOSH Health Hazard Evaluation Report: Montpelier High School, Montpelier, Vermont. Cincinnati, OH, National Institute for Occupational Safety and Health, HETA 92-108-2247.

Daisey, J.M., A.T. Hodgson, W.J. Fisk, M.J. Mendell and J. Ten Brinke (1994). Volatile organic compounds in twelve California office buildings: Classes, concentrations and sources. Atmospheric Environment, 28 (22): 3557-3562.

Daniels, W. (1983) NIOSH Health Hazard Evaluation Report: East Leyden High School, Franklin Park, Illinois, Cincinnati, OH, National Institute for Occupational Safety and Health, HETA 82-090-1274.

Daniels, W.J. and Connon, C.L. (1993) NIOSH Health Hazard Evaluation Report: Alamogordo High School, Alamogordo, New Mexico. Denver, CO, National Institute for Occupational Safety and Health, HETA 93-0515.

Decker, J.A. 1993) NIOSH Health Hazard Evaluation Report: Wakeland Elementary School, Brandenton, Florida. Atlanta, GA, National Institute for Occupational Safety and Health, HETA 93452.

Deitchman, S.D. and Fajen, J. (1993) NIOSH Health Hazard Evaluation Report: Schafer Middle School, Bensalem, Pennsylvania, Cincinnati, OH, National Institute for Occupational Safety and Health, HETA 93-0315.

DHS. (California Department of Health Services) (1983) Department memorandum from Peter Rank to the California Department of Housing and Community Development, June 20, 1983.

Dockery, D.W., Schwartz, J. and Spengler, J.D. (1992) Air pollution and daily mortality: Associations with particulates and acid aerosols. Environ. Research, 59: 362-373.

Donovan, B.A. (1994) NIOSH Health Hazard Evaluation Report: Princeton High School, Cincinnati, Ohio, Cincinnati, OH, National Institute for Occupational Safety and Health, HETA 93-0737-2393. 
Dotterud, L.R., Vorland, L.H. and Falk, E.S. (1996) Mould allergy in school children in relation to airborne fungi and residential characteristics in homes and schools in Northern Norway. Indoor Air, 6: 71-76.

Dybendal, T. and Elsayed, S. (1992) Dust from carpeted and smooth floor. V. Cat (Fel dD) and mite demonstration of the basophil histamine release induced by dust from classrooms, Clinical and Experimental Allergy, 22: 1100-1106.

Dybendal, T., Vik, H. and Elsayed, S. (1989) Dust from carpeted and smooth floors. 2. Antigenic and allergenic content of dust vacuumed from carpeted and smooth floors in schools under routine cleaning schedules, Allergy, 44: 401-411.

Edwards, M.M. (1991) Building Conditions, Parental Involvement, and Student Achievement in the D.C. Public School System. (Master's Thesis) Georgetown University, Washington, D.C.

Elliott, L.J. (1987) NIOSH Health Hazard Evaluation Report: St. John the Baptist School, Cincinnati, Ohio, Cincinnati, OH, National Institute for Occupational Safety and Health, HETA 88-024.

Elliott, L.J. (1988) NIOSH Health Hazard Evaluation Report: Patton Elementary School, Patton, Pennsylvania, Cincinnati, OH, National Institute for Occupational Safety and Health, HETA 89-046.

Elliott, L.J. and Baron, S. (1991) NIOSH Health Hazard Evaluation Report: Andrew Jackson Junior High School, Cross Lanes, WV, Cincinnati, OH, National Institute for Occupational Safety and Health, HETA 89-183-2101.

Ellringer, P. (1995) Indoor air quality concerns: Sick building syndrome. St. Paul, MN, Tamarack Environmental Consultants. Unpublished report.

Environ Corporation. (1994) Indoor Air Quality Investigation for Yucaipa Junior High School and Valley Elementary School, Irvine, CA.

Environmental Law Institute (1996) Law and Folicy Databases: Radon, Indoor Air Quality, and Electric and Magnetic Fields, Washington, DC, ELI (March).

Fisher, E., Harrison, J., Brennan, T. and Turner, W. (1990) The school evaluation program, Proceedings of the 1990 International Symposium on Radon and Radon Reduction Technology, Washington, DC, U.S. EPA, V, D-IX-7 Preprints.

Fisher, E., Ligman, B., Brennan, T., Shaughnessy, R., Turk, B. and Snead, B. (1995) Radon mitigation in schools utilizing heating, ventilation, and air conditioning systems, Radiation Protection Dosimetry, $56(1-4): 51-54$.

Fisk, W.J., M.J. Mendell, J.M. Daisey, D. Faulkner, A.T. Hodgson, M. Nematollahi, and J.M. Macher. (1993) Phase 1 of the California Healthy Building Study. Indoor Air, 3: 246-254.

Florida Indoor Air Quality Advisory Committee (1995) Indoor Air Quality Report: A Report to the Governor, President of the Senate, \& Speaker of the House, Tallahassee, FL, Florida Department of Management Services-Division of Facilities Management.

Frederick, L. and Love, J. (1981) NIOSH Health Hazard Evaluation Report: Our Lady of Visitation Elementary School, Cincinnati, $\mathrm{OH}$, Cincinnati, $\mathrm{OH}$, National Institute for Occupational Safety and Health, HETA 81-184-946.

Gallup, J.M., Zanolli, J. and Olson, L. (1993) Airborne bacterial exposure: preliminary results of volumetric studies performed in office buildings, schools, and homes in California, Proceedings of Indoor Air '93: The 6th International Conference on Indoor Air Quality and Climate, Vol. 4: 167170.

Gann, P. and Schirmer, I.H. (1984) NIOSH Health Hazard Evaluation Report: Upper School, Englewood Cliffs, New Jersey, Cincinnati, OH, National Institute for Occupational Safety and Health, HETA 82167-1460.

Gardener, C. (1985) Energy Conservation in Small Schools. Las Cruces, NM, Educational Resource Information Center Clearinghouse on Rural Education and Small Schools.

Gorman, R. W. (1988) NIOSH Health Hazard Evaluation Report: Withrow High School, Cincinnati, OH. Cincinnati, OH, National Institute for Occupational Safety and Health, HETA 87-213. 
Gorman, R. and Singal, M. (1984) NIOSH Health Hazard Evaluation Report: Wappingers Central School District, Wappingers Falls, New York, Cincinnati, OH, National Institute for Occupational Safety and Health, HETA 83-172-1409.

Gorman, R. and Aw, T.C. (1986) NIOSH Health Hazard Evaluation Report: Wasson Elementary School, Dubois, PA, Cincinnati, OH, National Institute for Occupational Safety and Health, HETA 84-2481694.

Gravesen, S., Larsen, L., Gyntelberg, F. and Skov, P. (1986) Demonstration of microorganisms and dust in schools and offices, Allergy, 41(7): 520-525.

Green, G.H., Sareen, K. and Osborne, A.D. (1985) The effect of ventilation and relative humidity upon airborne bacteria in schools, ASHRAE Transactions, 91, 2A: 13-28.

Gunter, B.J. and Koenig, J. (1988) Correspondence to L. Huber, Jefferson Elementary School, Minot North Dakota, Denver, CO, National Institute for Occupational Safety and Health.

Hanley, K.W., Klien, M. and Wilcox, T. (1992) NIOSH Health Hazard Evaluation Report: Western Primary School, Russiaville, Indiana, Cincinnati, $\mathrm{OH}$, National Institute for Occupational Safety and Health, HETA 92-107-2227.

Hanley, K.W., Wilcox, T. and Klien, M. (1991) NIOSH Health Hazard Evaluation Report: Western Primary School, Russiaville, Indiana, Cincinnati, $\mathrm{OH}$, National Institute for Occupational Safety and Health, HETA 91-143-2136.

Hansen, L., Bach, E., Kass Ibsen, K. and Osterballe, O. (1987) Carpeting in schools as an indoor pollutant, Indoor Air '87: Proceedings of 4th International Conference on Indoor Air Quality and Climate, Berlin (West), Institute of Water, Soil and Air Hygiene, vol. 2: 727-731.

Hanssen, S.O. (1993) Increased ventilation reduces general symptoms but not sensory reactions, Proceedings of Indoor Air '93: 6th International Conference on Indoor Air Quality and Climate, Vol. 5: 33-38.

Hodgson, A.T. (1995) A review and a limited comparison of methods for measuring total volatile organic compounds in indoor air. Indoor Air, 5: 247-257.

Hodgson, M.J. (1988) Health risk of indoor pollutants, Proceedings of IAQ '88: Engineering Solutions to Indoor Air, Atlanta, GA, American Society of Heating, Refrigerating, and Air-Conditioning Engineers, pp. 284-293.

ICF Kaiser (1994) Indoor Air Quality in Schools: An Evaluation of Studies Conducted in U.S. Schools, Washington, DC, U.S. EPA, Indoor Air Division (September 30 Draft).

Kaiser, E.A. (1988a) Correspondence to P. Dittami, Barbieri Elementary School, Framingham, Massachusetts. Boston, MA, National Institute for Occupational Safety and Health, HETA 88-078.

Kaiser, E.A. (1988b) Correspondence to G. Nye, Wasson Elementary School, DuBois, Pennsylvania, Boston, MA, National Institute for Occupational Safety and Health, HETA 88-078.

Kaiser, E.A. and Klincewicz, S. (1988) Correspondence to R. Cahn, Harrison-Morton Middle School and Jefferson Elementary School, Allentown, Pennsylvania, Boston, MA, National Institute for Occupational Safety and Health, HETA 88-241 (May 17 and August 30).

Kelly, J. (1992a) NIOSH Health Hazard Evaluation Report: Sporting Hill Elementary, Mechanicsburg, Pennsylvania, Cincinnati, OH, National Institute for Occupational Safety and Health, HETA 91-1912217.

Kelly, J. (1992b) NIOSH Health Hazard Evaluation Report: Cocalico, School District, Denver, Pennsylvania, Cincinnati, OH, National Institute for Occupational Safety and Health, HETA 91-1182213.

Kiefer, M., Van Gilder, T. And Decker, J. (1993) NIOSH Health Hazard Evaluation Report: Anclote Elementary School, New Port Richey, Florida, Cincinnati, OH, National Institute for Occupational Safety and Health, HETA 92-347-2287. 
Kinnes, G.M. and Bresler, F.T. (1993) NIOSH Health Hazard Evaluation Report: Thornapple-Kellogg Middle School, Middleville, Michigan, Cincinnati, $\mathrm{OH}$, National Institute for Occupational Safety and Health, HETA 93-0121.

Kominsky, J.R. (1982) NIOSH Health Hazard Evaluation Report: Miamitown Grade School, Cincinnati, Ohio, Cincinnati, OH, National Institute for Occupational Safety and Health, HETA 82-068-1111.

Kominsky, J.R. (1987) NIOSH Health Hazard Evaluation Report: Seattle Public Schools, Seattle, Washington, Cincinnati, $O H$, National Institute for Occupational Safety and Health, HETA 85-0721850.

Koskinen, O., Husman, T., Hyvarinen, A., Reponen, T., and Nevalainen, A. (1995) Respiratory symptoms and infections among children in a day-care center with mold problems. Indoor Air, 5: 3-9.

Koskinen, O.M., Husman, T.M., Hyvarinen, A.M., Reponen, T.A. and Nevalainen, A.I. (1997) Two moldy day-care centers: a follow-up study of respiratory symptoms and infections. Indoor Air, 7: $262-268$.

Lagus Applied Technology (1995) Air Change Rates in Non-residential Buildings in California, Sacramento, CA, California Energy Commission, P400-91-034BCN.

Laurent, A.M., Person, A., Petit-Coviaux, F., Le Moullec, Y., and Festy, B. (1993) Chemical characterization of indoor air quality inside schools in Paris, Proceedings of Indoor Air '93: The 6th International Conference on Indoor Air Quality and Climate, Helsinki, Finland, July 4-8, 1993, Vol. 3: 23-28.

Lee, S.A. (1986) NIOSH Health Hazard Evaluation Report: Mid Valley School, Throop, Pennsylvania, Cincinnati, OH, National Institute for Occupational Safety and Health, HETA 85-454-1695.

Lee, S.A. and Hales, T.R. (1993a) NIOSH Health Hazard Evaluation Report: West Middle School, Grand Junction, CO, Denver, CO, National Institute for Occupational Safety and Health, HETA 93344.

Lee, S.A. and Hales, T.R. (1993b) NIOSH Health Hazard Evaluation Report: Margaret Leary School, Butte, Montana, Denver, CO, National Institute for Occupational Safety and Health, HETA 93-063.

Leovic, K.W., Harris, D.B., Dyess, T.M., Pyle, B.E., Borak, T. And Saum, D.W. (1991) HVAC system complications and controls for radon reduction in school buildings, Proceedings of the 1991 International Symposium on Radon and Radon Reduction Technology, Washington, DC, U.S. EPA, EPA, 2: 10.85-10.104.

Leovic, K. (1990) Summary of EPA's Radon Reduction Research in Schools During 1989-90, Washington, DC, U.S. EPA, EPA-600/8-90-072.

Lipfert, F.W. and R.E. Wyzga. Air pollution and mortality: Issues and uncertainties. J. Air \& Waste Manage. Assoc., 45: 949-966 (1995).

Liss, G.M. and Ahrenholz, S.H. (1982) NIOSH Health Hazard Evaluation Report: William Blount High School, Maryville, Tennessee, Cincinnati, $\mathrm{OH}$, National Institute for Occupational Safety and Health, HETA 82-342-1223.

Liu, S.T., Hunt, C.M. and Powell, F.J. (1977) Evaluation of Ventilation Requirements and Consumption in Existing New York City School, Washington, DC, National Bureau of Standards Building Science Series 97.

Macher, J. M., A.J. Streifel, and D. Vesley. (1992) Problem buildings, laboratories and hospitals. In: Bioaerosols - Handbook of Samplers and Sampling. C.M. Wathes \& C.S. Cox, Eds., Lewis Publishers, Inc., Chelsea, MI.

Malkin, R. and Earnest, G. S. (1993) NIOSH Health Hazard Evaluation Report: Muffin Middle School, Columbus, Ohio, Cincinnati, OH, National Institute for Occupational Safety and Health, HETA 93391.

Malkin, R., T. Wilcox, and W.K. Sieber (1996) The National Institute for Occupational Safety and Health Indoor Environmental Evaulation Experience. Part Two: Symptom prevalence. Appl. Occup. Environ. Hyg., 11: 540-545. 
Maroni, M., Bersani, M., Cavallo, D., Anversa, A., and Alcini, D. (1993) Microbial contamination in buildings: comparison between seasons and ventilation systems, Proceedings of Indoor Air '93: The 6th International Conference on Indoor Air Quality and Climate, Helsinki, Finland, July 4-8, 1993, Vol. 4: 137-142.

Martinez, K.F., Petsonk, L. and Kinnis, G. (1992) NIOSH Health Hazard Evaluation Report: Houghtaling Elementary School, Ketchikan, Alaska, Cincinnati, OH, National Institute for Occupational Safety and Health, HETA 92-0074-2452.

Martinez, K.F. and Ruder, A.M. (1993) NIOSH Health Hazard Evaluation Report: New Iberia Senior High School, New Iberia, Louisiana, Cincinnati, $\mathrm{OH}$, National Institute for Occupational Safety and Health, HETA 93-0312.

Mattorano, D.A., Burr, G.A. and Robinson, C. (1993) NIOSH Health Hazard Evaluation Report: Central East Middle School, Philadelphia, Pennsylvania, Cincinnati, OH, National Institute for Occupational Safety and Health, HETA 93-615.

McCammon, C. (1990) NIOSH Health Hazard Evaluation Report: Johnson Junior High School, Cheyenne, Wyoming, Cincinnati, OH, National Institute for Occupational Safety and Health, HETA 90-170.

McManus, K.P. (1982) NIOSH Health Hazard Evaluation Report: Indian Brook Elementary School, Plymouth, Massachusetts, Cincinnati, $\mathrm{OH}$, National Institute for Occupational Safety and Health, HETA 82-372-1220.

McManus, K.P. (1986) NIOSH Health Hazard Evaluation Report: Lincoln Sudbury High School, Sudbury, Massachusetts, Cincinnati, $\mathrm{OH}$, National Institute for Occupational Safety and Health, RTA 1-86-229.

McManus, K.P. (1987a) NIOSH Health Hazard Evaluation Report: New Searles Road School, Nashua, New Hampshire, Boston, MA, National Institute for Occupational Safety and Health, HETA 87-135.

McManus, K.P. (1987b) NIOSH Health Hazard Evaluation Report: Wilbraham Middle School, Wilbraham, Massachusetts, Boston, MA, National Institute for Occupational Safety and Health, HETA 87-

McManus, K.P. (1988) NIOSH Health Hazard Evaluation Report: St. Ignatius Elementary School, West Lawn, Pennsylvania, Boston, MA, National Institute for Occupational Safety and Health, HETA 88186.

McManus, K.P. (1989a) NIOSH Health Hazard Evaluation Report: Malden High School, Malden, Massachusetts, Boston, MA, National Institute for Occupational Safety and Health, HETA 89-002.

McManus, K.P. (1989b) NIOSH Health Hazard Evaluation Report: Southwick High School, Southwick, Massachusetts, Boston, MA, National Institute for Occupational Safety and Health, HETA 89-169.

Meklin, T., Taskinen, T. and Nevalainen, A. (1996) Microbial characterization of four school buildings. Proceedings of Indoor Air '96: The 7th International Conference on Indoor Air Quality and Climate, Nagoya, Japan, July, 1996, Vol. 2: 1083-1088.

Mendell, M.J., W.J. Fisk, J.A. Deddens, W.G. Seavey, A.H. Smith, D.F. Smith, A.T. Hodgson,J.M. Daisey, and L. Goldman. (1996) Elevated symptom prevalence associated with ventilation type in office buildings: Findings from the California Healthy Building Study, Phase 1. Epidemiology, 7:583-589.

Michel, O., B. LeBon, J. Duchateau, F. Vertongen, R. Sergysels. (1989) Domestic endotoxin exposure in asthma. European Respiratory Journal, 2: 1019-1020.

Molhave, L. (1990) Volatile organic compounds, indoor air quality and health. Proceedings of the 5th 'International Conference on Indoor Air Quality and Climate, Indoor Air '90, Vol. 5: 15-34.

Molhave, L., B. Bach and O.F. Pedersen (1986). "Human reactions to low concentrations of volatile organic compounds." Environment International 12: 167-175.

Molhave, L. Gronkjaer, and S. Larsen. (1991) Subjective reactions to volatile organic compounds as air pollutants. Atmos. Environ., 25A: 1283-1293. 
Morey, P.R. (1984) Case presentation: problems caused by moisture in occupied office buildings. Annals of the American Conference of Industrial Hygienists, 10: 121-127.

Mouilleseaux, A., Squinazi, F., and Festy, B. (1993) Microbial characterization of air quality in classrooms, Proceedings of Indoor Air '93: The 6th International Conference on Indoor Air Quality and Climate, Helsinki, Finland, July 4-8, 1993, Vol. 4: 195-200.

Munir, A.K., Einarsson, R., Schou, C. and Drebork, S.K (1993) Allergens in school dust. I. The amount of major cat (Fel d I) and dog (Can $f($ ) allergens in dust from Swedish schools is high enough to probably cause perennial symptoms in most children with asthma who are sensitized to cat and dog. Journal of Allergy and Clinical Immunology, 91: 1067-1074.

Myhrvold, A.N., Olsen, E., and Lauridsen, O. (1996) Indoor environment in schools - pupils health and performance in regard to $\mathrm{CO} 2$ concentrations. Proceedings of Indoor Air '96: The 7th International Conference on Indoor Air Quality and Climate, Nagoya, Japan, July 21-26, 1996, Vol. 4: pp. 369374.

National Institute for Occupational Safety and Health (1994) NIOSH Health Hazard Evaluation Report: H.E. McCracken Middle School, Hilton Head, South Carolina, Cincinnati, OH, National Institute for Occupational Safety and Health, HETA 95-0114-P.

Nielsen O. (1984) Quality of air and the amount of fresh air in classrooms, Indoor Air: Buildings, Ventilation and Thermal Climate. Berglund, B., Lindvall, T. and Sundell, J. (eds.) Swedish Council for Building Research, 5, 221-226.

Nelson, N.A., Kaufman, J.D., Burt, J., and Karr, C. (1995) Health symptoms and the work environment in four non-problem United States office buildings. Scand. J. Work Environ. Health, 21: 51-59.

Nelson, C.J., Clayton, C.A., Wallace, L.A., Highsmith, V.R., Kollander, M., Bascom, R. and Leaderer, B.P. (1991) EPA's indoor air quality and work environment survey: Relationship of Employees' selfreported health symptoms with direct indoor air quality measurements, $1 A Q$ '91: Healthy Buildings, Atlanta, GA, American Society of Heating, Refrigerating and Air-Conditioning Engineers, 22-32.

Norback, D. and Torgen, M. (1987) A longitudinal study of symptoms associated with wall-to-wall carpets and electrostatic charges in Swedish school buildings. Indoor Air '87: Proceedings of 4th International Conference on Indoor Air Quality and Climate, Berlin (West), Institute of Water, Soil and Air Hygiene, 3, 3, 57-361.

Norback, D., Torgen, M. and Edling, C. (1990) Volatile organic compounds, respirable dust, and personal factors related to prevalence and incidence of sick building syndrome in primary schools, British Journal of Industrial Medicine, 47: 733-741.

Norback, D. (1995) Subjective indoor air quality in schools - the influence of high room temperature, carpeting, fleecy wall materials and volatile organic compounds. Indoor Air, 5: 237-246

Olsen, J.H. and M. Dossing. (1982) Formaldehyde induced symptoms in day care centers. Am. Ind. Hyg. Assoc. J., 43: 366-370.

Orris, P. and Kominsky, J.R. (1984) NIOSH Health Hazard Evaluation Report: Hill-Murray High School, Maplewood, Minnesota, Cincinnati, OH, National Institute for Occupational Safety and Health, HETA 82-310-1475.

Parker, J. D. (1992) HVAC Systems in the Current Stock of U.S. Schools, Washington, DC, U.S. EPA, EPA-600/R-92-125.

Pepler, R.D. and Warner, R.E. (1968) Temperature and learning: an experimental study. ASHRAE Trans., 74 (Pt. 2): 211-219.

Persily, A. and W.S. Dols. (1990) The relation of $\mathrm{CO}_{2}$ concentration to office building ventilation. In: Air Change Rate and Airtightness in Buildings, ASTM STP 1067, M.H. Sherman, Ed., American Society for Testing and Materials, Philadelphia, pp. 77-92.

Piacitelli, L. (1983) NIOSH Health Hazard Evaluation Report: Saint Francis High School, Morgantown, West Virginia, Cincinnati, OH, National Institute for Occupational Safety and Health, HETA 83-1121309. 
Piacitelli, L. (1984) NIOSH Health Hazard Evaluation Report: Chemung County Health Department, Elmira, New York, Cincinnati, OH, National Institute for Occupational Safety and Health, HETA 83139-1422.

Platts-Mills, T.A.E., Sporik, R., Ingram, J.M., and Honsinger, R. (1995) Dog and cat allergens and asthma among school children in Los Alamos, New Mexico, USA - Altitude 7,200 feet. Intern. Arch. Allerg. Immunol., 107 (1-3): 301-303.

Potting, J., van de Sandt, P., ter Haar Romeny-Wacher, I., Brunekreef, B. and J.S.M. (1987) Health complaints, $\mathrm{CO}_{2}$ levels and indoor climate in Dutch schools. Indoor Air '87: Proceedings of 4th International Conference on Indoor Air Quality and Climate, Berlin (West), Institute of Water, Soil and Air Hygiene, Volume 3, 582-586.

Rao, C.Y., H.A. Burge, and J.C.S. Chang. (1996). Review of quantitative standards and guidelines for fungi in indoor air. J. Air \& Waste Manage. Assoc., 46: 899-908.

Reed, C.E. and M.C. Swanson. (1986) Indoor allergens: identification and quantification. Environment International, 12: 115-120.

Regents Advisory Committee. (1994a) Environmental Quality of Schools, Albany, NY, Regents of the University of the State of New York.

Regents Advisory Committee. (1994b) Public Comment on the Report of the Regents Advisory Committee on Environmental Quality of Schools and Recommendations to Improve the Environmental Health and Safety of Schools, Albany, NY, Regents of the University of the State of New York.

Rhodes, W.W., Gilyard, Y.O. and Kirihara, J.K. (1993) The IAQ achetype, part 1: The interrelationship between design and actual installation of HVAC systems. Proceedings of Indoor Air '93 6th International Conference on Indoor Air and Climate, Volume 2, 699-704.

Rindel, A. Bach, E., Breum, N.O., Hugord, C., and Schneider, T. (1987) Correlating health effect with indoor air quality in kindergartens, Int. Arch. Occup. Environ. Health, 59(4): 363-373.

Roper, P. and Deitchman, S. (1988) NIOSH Health Hazard Evaluation Report: Coudersport Elementary School, Coudersport, Pennsylvania, Atlanta, GA, National Institute for Occupational Safety and Health, HETA 88-178.

Rylander, R., S. Sorensen, H. Goto, K. Yuasa, S. Tanaka. (1989) The importance of endotoxin and glucan for symptoms in sick buildings. In: Bieva, C.J., Coutois, Y.; and Govaerts, M., Eds., Present and Future of Indoor Air Quality, Proceedings of the Brussels Conference, Excerpta Medica, New York, 1989, pp. 219-226.

Rylander, R., K. Persson, H. Goto and S. Tanaka. (1992) Airborne beta-1,3-glucan may be related to symptoms in sick buildings. Indoor Environment, 1: 263-267.

Salisbury, S. and Scarf, T. (1993) NIOSH Health Hazard Evaluation Report: Athens High School, Athens, Alabama, Atlanta, GA, National Institute for Occupational Safety and Health, HETA 93-316.

Samet, J.M., Marbury, M.C. and Spengler, J.D. (1987) Health Effects and Sources of Indoor Air Pollution, Part I, American Review of Respiratory Disease, 136, 1486-1508.

Samet, J.M., Marbury, M.C. and Spengler, J.D. (1988) Health Effects and Sources of Indoor Air Pollution, Part II, American Review of Respiratory Disease, 137: 221-242.

Sanderson, W.T. (1988) NIOSH Health Hazard Evaluation Report: Dehue-Chambers Grade School, Logan, West Virginia, Morgantown, WV, National Institute for Occupational Safety and Health, MHETA 88-231.

Schwartz, J. Particulate air pollution and chronic respiratory disease. Environ. Research, 62: 7-13 (1993).

Seitz, T. and Etzel, R.A. (1988) NIOSH Health Hazard Evaluation Report: Marcus Hook Grade School, Marcus Hook, Pennsylvania, Cincinnati, OH, National Institute for Occupational Safety and Health, HETA 88-245.

Shaughnessy, R.J., Turk, B., Levetin, E., Brennan, T., Fisher, E. and Ligman, B. (1993) Impact of ventilation/pressurization on indoor air contaminants in schools (draft), Washington, DC, U.S. EPA. 
Sheldon, L.S., Handy, R.W., Hartwell, T.D., Whitmore, R.W. and Zelon, H.S. (1989a) Indoor Air Quality in Public Buildings, Volume 1, Washington, DC, U.S.EPA-Environmental Monitoring Systems Laboratory, NTIS/PB89-102503.

Sheldon, L.S., Zelon, H.S., Sickles, J., Eaton, C. and Hartwell, T. (1989b) Indoor Air Quality in Public Building, Volume 2, Washington, DC, U.S. EPA-Environmental Monitoring Systems Laboratory, NTIS/PB89-102511. (see also Sheldon, L.S., R.W. Handy, T.D. Hartwell, R.W. Whitmore, H.S. Zelon and E.D. Pellizzari. (1988) Indoor Air Quality in Public Buildings, Volumes I and II, EPA/600/6-88/009a and EPA/600/6-88/009b.)

Sim, M. and Bryant, C.J. (1993) NIOSH Health Hazard Evaluation Report: Tewksbury Memorial High School, Tewksbury, Massachusetts, Cincinnati, $\mathrm{OH}$, National Institute for Occupational Safety and Health, HETA 93-287.

Smedje, G., Norback, D., and Edling, C. (1997) Subjective indoor air quality in schools in relation to exposure. Indoor Air, 7: 143-150.

Smedje, G., Norback, D., Wessen, B. and Edling, C. (1996) Asthma among school employees in relation to the school environment. Proceedings of Indoor Air '96: The 7th International Conference on Indoor Air Quality and Climate, Nagoya, Japan, July 21-26, 1996, Vol. 1, pp. 611-616.

Stock, T. H. and Venso, E.A. (1993) The impact of residential evaporative air cooling on indoor exposure to ozone. Proceedings of the $6^{\text {th }}$ International Conference on Indoor Air Quality ad Climate, Helsinki, Finland, , Vol. 3: pp. 251-256.

Tepper, A.; Martinez, K.; Buchta, T. (1994) NIOSH Health hazard evaluation report: Lakeland Jr-Sr High School, Jermyn, Pennsylvania. National Institute for Occupational Safety and Health, Cincinnati, OH. HETA-92-0126-2358.

Thompson, C.R., Hensel, E.G. and Kats, G. (1973) Outdoor-indoor levels of six air pollutants, Journal of the Air Pollution Control Association, 23:10: 881-886.

Thome, P.S. (1993) Sump additives as a source of bioaerosols in a school building, Veterinary and Human Toxicology, 32: 2: 141-143.

Thorstensen, E., Hansen, C., Pejtersen, J., Clausen, G.H. and Fanger, P.O. (1990) Air pollution sources and indoor air quality in schools, Indoor Air '90: Proceedings of the 5th International Conference on Indoor Air Quality and Climate, Toronto, ON, Vol. 1: 531-536.

Turk, B.H., Brown, J.T., Geisling-Sobotka, K., Froehlick, D.A., Grimsrud, D.T., Harrison, J., Koonce, J.F., Prill, R.J. and Revzan, K.L. (1987a) Indoor Air Quality Ventilation Measurements in 38 Pacific Northwest Commercial Buildings, Berkeley, CA, Lawrence Berkeley Laboratory, LBL-22315.

Turk, B.H., Grimsrud, D.T., Brown, J.T., Geisling-Sobotka, K., Harrison, J. and Prill, R.J. (1987b) Commercial building ventilation rates and particle concentrations, Proceedings of Indoor Air '87: The 4th International Conference on Indoor Air Quality and Climate, West Berlin, West Germany, IWSAH.

Turk, B.H., Grimsrud, D.T., Brown, J.T., Geisling-Sobotka, K., Harrison, J. and Prill, R.J. (1989) Commercial building ventilation rates and particle concentrations, ASHRAE Transactions, 95: 422433.

Turk, B.H., Powell, G., Fisher, E., Ligman, B., Harrison, J., Brennan, T. and Shaughnessy, R. (1993) Improving general indoor air quality while controlling specific pollutants in schools. Proceedings of Indoor Air '93: The 6th International Conference on Indoor Air Quality and Climate, Helsinki, Finland, Vol. 6: 705-710.

Turner, W.A., McKnight, F.T., Luckury, R.K. and Bearg, D.W. (1993) Use of a standardized diagnostic protocol for diagnostic evaluation and mitigation of schools that have been vacated because of occupant perceived unacceptable indoor air quality, Proceedings of Indoor Air '93: The 6th International Conference on Indoor Air Quality and Climate, Vol. 6: 711-716.

U.S. GAO. (1995a) School Facilities: Condition of America's Schools, U.S. General Accounting Office, Washington, DC, GAO, GAO/HEHS-95-61. 
U.S. GAO (1995b) School Facilities: Profile of School Conditions by State, U.S. General Accounting Office, Washington, DC, GAO/HEHS-96-148.

U.S. GAO (1996) School Facilities: America's Schools Report Differing Conditions, U.S. General Accounting Office, Washington, DC, GAO, GAO/HEHS-96-103.

Verhoeff, A.P., Van Strien, T.T.,Van Wijnen, J.H. and Brunekreef, B. (1994) House dust mite allergen (Der p I) and respiratory symptoms in children: a case-control study. Clinical and Experimental Allergy, 24: 1061-1069.

Wallace, L., Pellizzari, E. and Wendel, C. (1991) Total volatile organic concentrations in 2700 personal, indoor, and outdoor air samples collected in the U.S. EPA Team studies. Indoor Air, 1: 465-477.

Walllingford, K.M. (1986) NIOSH Health Hazard Evaluation Report: Hegins-Hubley Elementary School, Valley View, Pennsylvania, Cincinnati, $\mathrm{OH}$, National Institute for Occupational Safety and Health, HETA 86-079.

Warner, J.A. (1992) Editorial. Environmental allergen exposure in homes and schools. Clinical and Experimental Allergy, 22: 1044-1045.

Weschler, C.J., H.C. Shields, and D.V. Naik. (1989) Indoor ozone exposures. Journal of the Air Pollution Control Association, 39: 1562-1568.

WHO (1979) Health Aspects Related to Indoor Air Quality. World Health Organization, Report on a WHO Working Group. EURO Reports and Studies 21, Bilthoven. Regional Office for Europe, Copenhagen.

WHO (1987) Air quality guidelines for Europe. World Health Organization, WHO Regional Publications, European Series No. 23, Copenhagen.

Wyon, D.P., I.B. Anderson, and G.R. Lundqvist. (1979) The effects of moderate heat stress on mental performance. Scand. J. Work, Environ. Health, 5: 352-361.

Zey, J.N. (1985) NIOSH Health Hazard Evaluation Report: Wyoming High School, Wyoming, Ohio, Cincinnati, OH, National Institute for Occupational Safety and Health, HETA 85-085-1615.

Zimmer, A.T. and Staynor, L.T. (1993) NIOSH Health Hazard Evaluation Report: Roosevelt Elementary School, Yakima, Washington, Cincinnati, $\mathrm{OH}, \mathrm{National}$ Institute for Occupational Safety and Health, HETA 93-384. 
APPENDICES 


\section{Appendix A}

Pre-Investigation Health and Environmental Complaints, 53 NIOSH School Health Hazard Evaluation Reports, 1981 - 1994

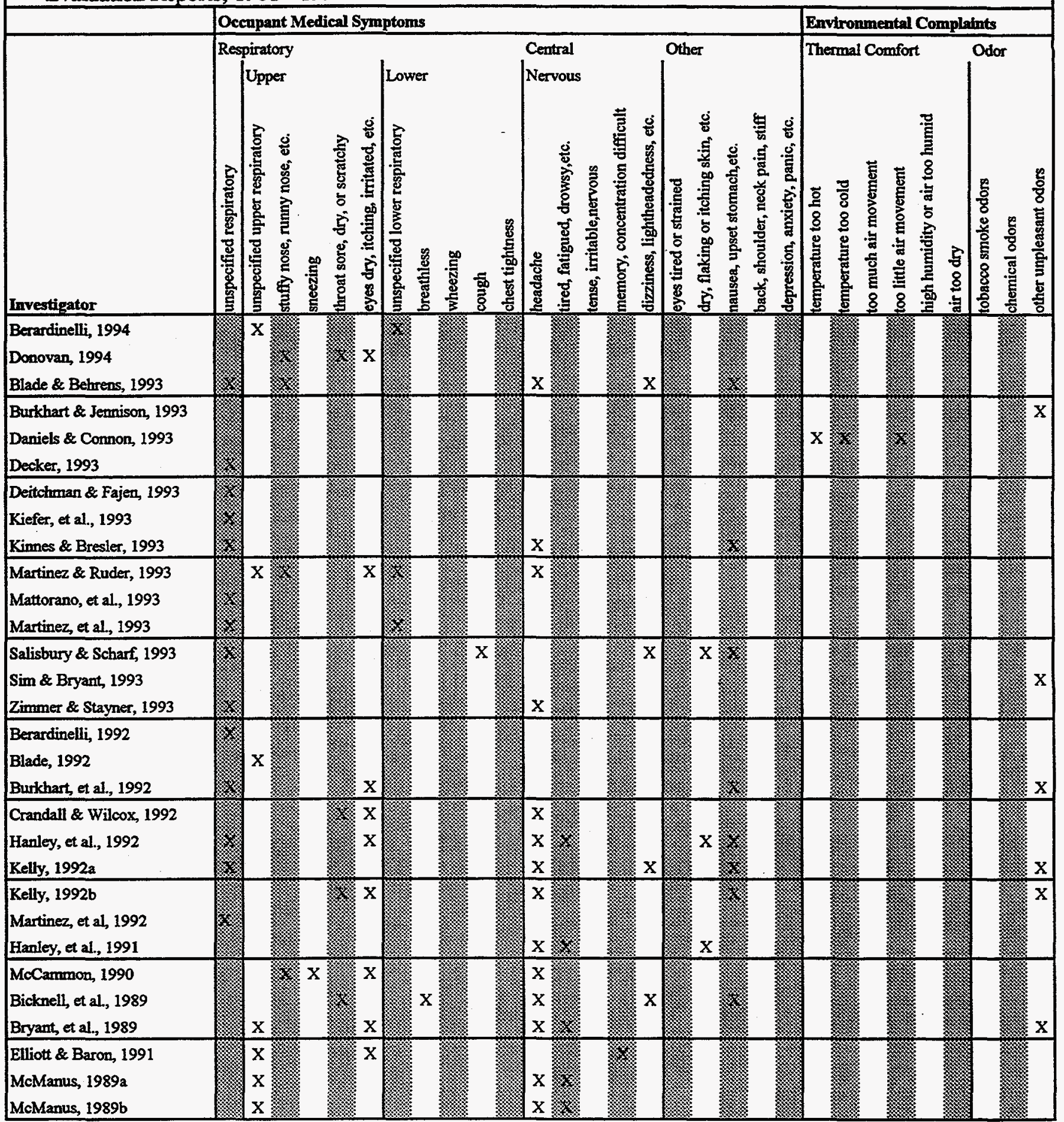




\section{Appendix A (continued)}

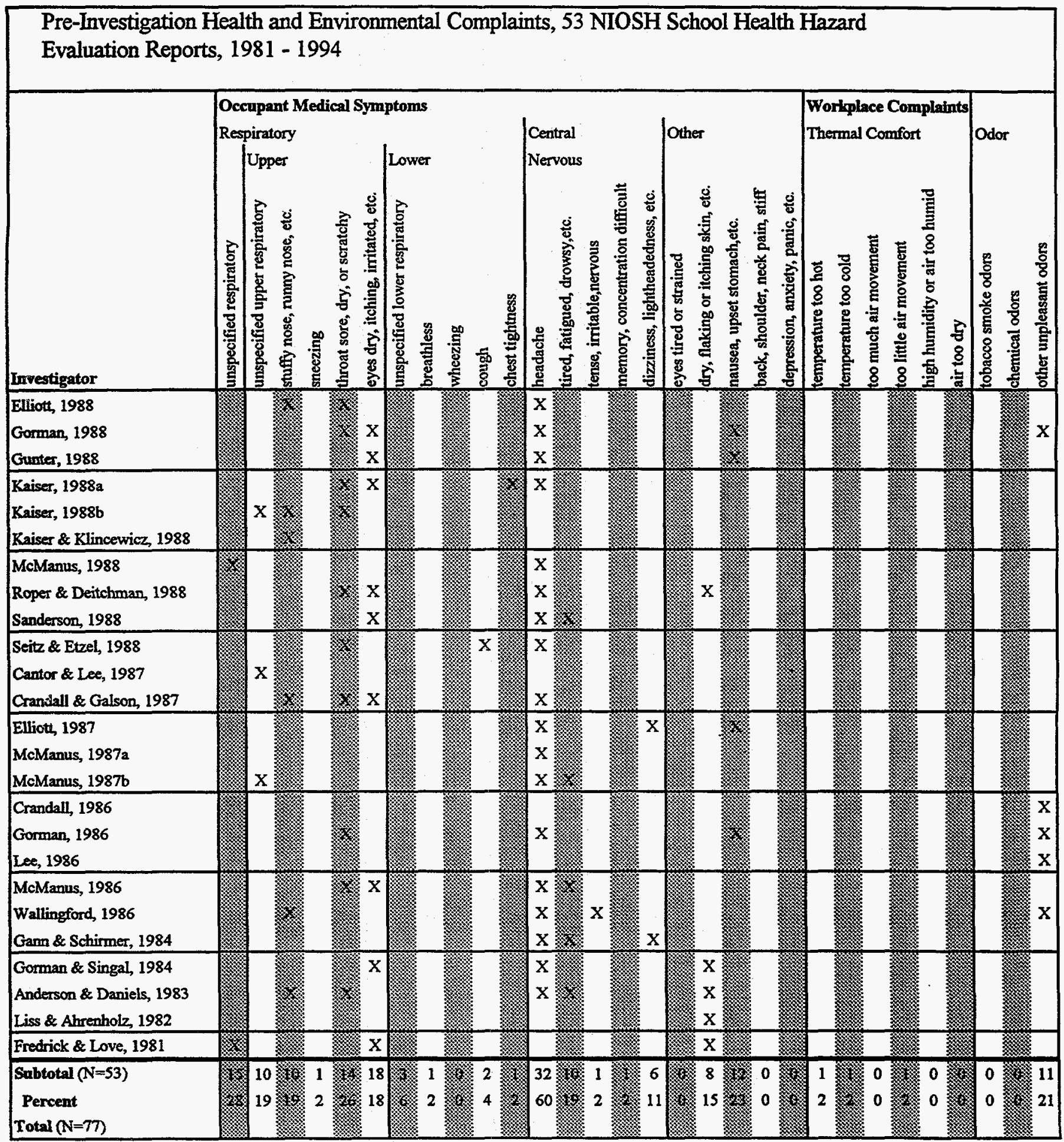




\section{Appendix B}

Health Symptoms and Environmental Complaints in Percent, 26 NIOSH School Health Hazard Evaluation Reports, 1983 - 1994

\begin{tabular}{|c|c|c|c|c|c|c|c|c|c|c|c|c|c|c|c|c|c|c|c|c|c|c|c|c|c|c|c|c|}
\hline $\mathbf{v}$ & 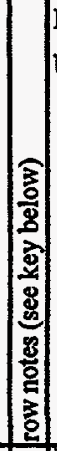 & 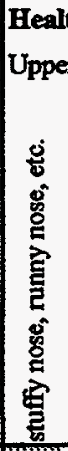 & 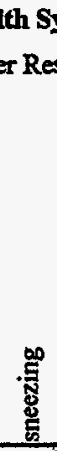 & 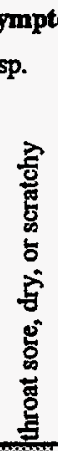 & 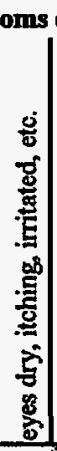 & 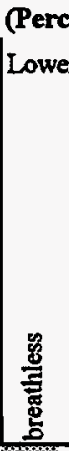 & 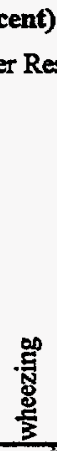 & क्षేّ & 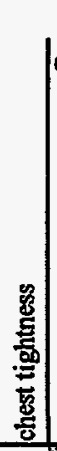 & 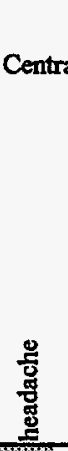 & 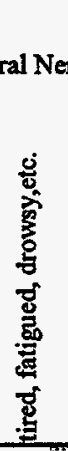 & 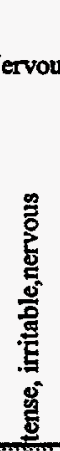 & 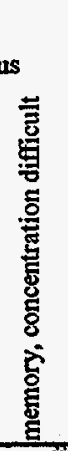 & 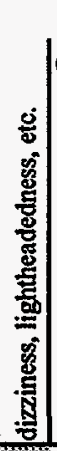 & 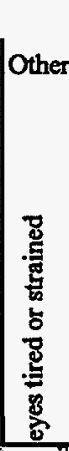 & 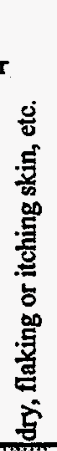 & 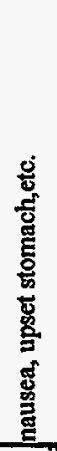 & 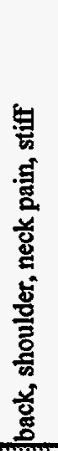 & 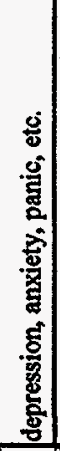 & 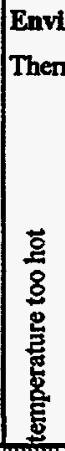 & 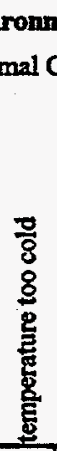 & 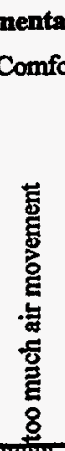 & 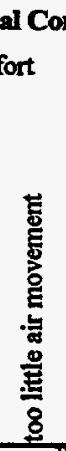 & 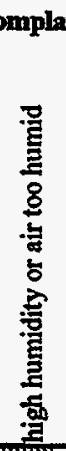 & 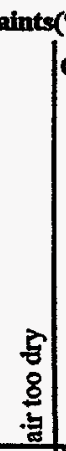 & 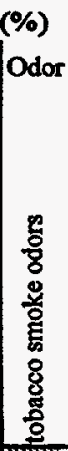 & $\frac{\frac{0}{8}}{\frac{8}{8}}$ & 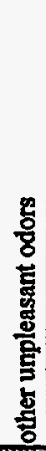 \\
\hline 994 & $\Rightarrow$ & 慈 & & L & 32 & & 78 & & 7 & 秋 & $\begin{array}{l}\text { tions } \\
11 \\
\end{array}$ & 奴叕 & ient & 极 & & 5 & 43 & 苭妙 & ing & 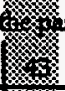 & 40 & & 50 & 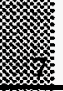 & 36 & & & 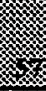 \\
\hline $\begin{array}{l}\text { Jonovan } \\
994 \\
N=18 / 19 \text { ) }\end{array}$ & c, & 器 & $\begin{array}{r}7 \\
21 \\
14\end{array}$ & 聯聯 & $\begin{array}{l}14 \\
29 \\
29\end{array}$ & 兹 & $\begin{array}{l}0 \\
0 \\
0\end{array}$ & 聯聯 & 吸 & 聯聯聯 & $\begin{array}{l}21 \\
36 \\
21\end{array}$ & 聯森 & $\begin{array}{c}0 \\
21 \\
14\end{array}$ & 聯 & $\begin{array}{l}21 \\
36 \\
36\end{array}$ & 楸 & $\begin{array}{r}7 \\
29 \\
7\end{array}$ & 聯 & $\begin{array}{l}0 \\
7\end{array}$ & 聯 & $\begin{array}{l}21 \\
43\end{array}$ &  & $\begin{array}{l}43 \\
43\end{array}$ & 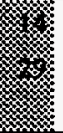 & $\begin{array}{l}21 \\
29\end{array}$ & & $\begin{array}{l}0 \\
14\end{array}$ & 然 \\
\hline $\begin{array}{l}\text { lade, } \\
\text { ehrens } \\
993 \text { N }\end{array}$ & e & 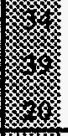 & $\begin{array}{r}7 \\
15 \\
5 \\
\end{array}$ & 聯 & $\begin{array}{l}37 \\
37 \\
34\end{array}$ & 聯 & $\begin{array}{l}0 \\
0 \\
0 \\
\end{array}$ & 森森 & $\begin{array}{r}12 \\
5 \\
5\end{array}$ & 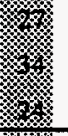 & $\begin{array}{l}15 \\
20 \\
12 \\
\end{array}$ & 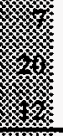 & $\begin{array}{r}7 \\
15 \\
2 \\
\end{array}$ & 聯 & $\begin{array}{l}37 \\
39 \\
27\end{array}$ & 紗 & $\begin{array}{r}5 \\
10 \\
2 \\
\end{array}$ & 聯 & $\begin{array}{r}10 \\
17 \\
7\end{array}$ & 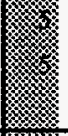 & 12 & ) & $\begin{array}{l}15 \\
17\end{array}$ & 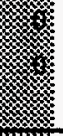 & $\begin{array}{l}29 \\
32\end{array}$ & & $\begin{array}{l}2 \\
2\end{array}$ & \\
\hline $\begin{array}{l}\text { Burkhart, } \\
\text { Tennison } \\
1993 \text { (N=38/4 }\end{array}$ & c, & 器 & $\begin{array}{l}11 \\
16 \\
11\end{array}$ & 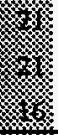 & $\begin{array}{l}37 \\
39 \\
29 \\
\end{array}$ & 聯 & $\begin{array}{l}0 \\
3 \\
0\end{array}$ & 聯 & $\begin{array}{l}5 \\
0 \\
0\end{array}$ & 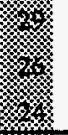 & $\begin{array}{l}45 \\
55 \\
34\end{array}$ & 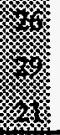 & $\begin{array}{l}21 \\
18 \\
8\end{array}$ & 聯 & $\begin{array}{l}37 \\
29 \\
18\end{array}$ & z & $\begin{array}{l}5 \\
8 \\
8\end{array}$ & 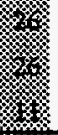 & $\begin{array}{r}8 \\
13 \\
5 \\
\end{array}$ & 聯 & & & $\begin{array}{l}63 \\
63\end{array}$ & . & $\begin{array}{l}18 \\
26\end{array}$ & & $\begin{array}{l}16 \\
21\end{array}$ & 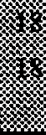 \\
\hline $\begin{array}{l}\text { Connon } \\
1993(N=44 / 47)\end{array}$ & c, & 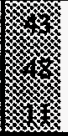 & $\begin{array}{r}18 \\
27 \\
9\end{array}$ & 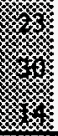 & $\begin{array}{l}43 \\
45 \\
20\end{array}$ & 森森 & $\begin{array}{r}5 \\
14 \\
9 \\
\end{array}$ & 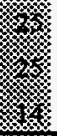 & $\begin{array}{l}2 \\
7 \\
2\end{array}$ & 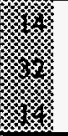 & $\begin{array}{l}30 \\
36 \\
18\end{array}$ & 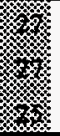 & $\begin{array}{l}11 \\
14 \\
5\end{array}$ & 樊 & $\begin{array}{l}36 \\
39 \\
23\end{array}$ & & $\begin{array}{r}14 \\
14 \\
7\end{array}$ & 聯 & $\begin{array}{r}14 \\
11 \\
2\end{array}$ & 猋 & 52 & 聯 & $\begin{array}{l}25 \\
25\end{array}$ & 签 & $\begin{array}{l}18 \\
18\end{array}$ & 䒽 & $\begin{array}{l}30 \\
11\end{array}$ & 聯 \\
\hline $\begin{array}{l}\text { Burr, } \\
\text { al. } \\
1993(N=92 / 92)\end{array}$ & c, & 齐 & & 納 & $\begin{array}{r}10 \\
13 \\
5 \\
\end{array}$ & 梦 & $\begin{array}{l}2 \\
3 \\
0 \\
\end{array}$ & x. & $\begin{array}{l}3 \\
4 \\
0\end{array}$ & x & $\begin{array}{l}18 \\
27 \\
12\end{array}$ & & 0 & 陊 & 10 & & & & & 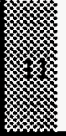 & & & 12 & & 8 & & 1 & 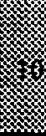 \\
\hline $\begin{array}{l}\text { Deitchman, } \\
\text { Fajen } \\
1993(\mathrm{~N}=42 / 42)\end{array}$ & c, & 㡭 & $\begin{array}{r}21 \\
10 \\
0\end{array}$ & 慈 & $\begin{array}{l}57 \\
38 \\
14 \\
\end{array}$ & 聯 & $\begin{array}{r}10 \\
7 \\
2 \\
\end{array}$ & 聯 & 幄 & 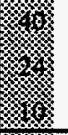 & $\begin{array}{r}40 \\
31 \\
7 \\
\end{array}$ & 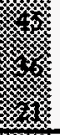 & $\begin{array}{l}31 \\
14 \\
7\end{array}$ & 慈 & $\begin{array}{l}43 \\
29 \\
14\end{array}$ & 聯 & $\begin{array}{r}12 \\
5 \\
2 \\
\end{array}$ & 聯聯 & $\begin{array}{r}19 \\
10 \\
5\end{array}$ & 聯烈 & $\begin{array}{l}36 \\
19\end{array}$ & 玆 & $\begin{array}{l}62 \\
45\end{array}$ & 㹡 & $\begin{array}{l}33 \\
21\end{array}$ & 聯 & $\begin{array}{l}17 \\
14\end{array}$ & 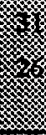 \\
\hline $\begin{array}{l}\text { ee, } \\
\text { Lales, } 1993 \\
N=17 / 20 \text { ) }\end{array}$ & a, & 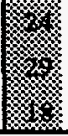 & $\begin{array}{c}12 \\
6 \\
6 \\
\end{array}$ & & $\begin{array}{l}35 \\
29 \\
18\end{array}$ & 聯森 & $\begin{array}{l}0 \\
0 \\
6\end{array}$ & 䜌 & $\begin{array}{l}0 \\
0 \\
0\end{array}$ & 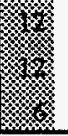 & $\begin{array}{l}18 \\
29 \\
12\end{array}$ & 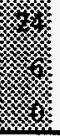 & $\begin{array}{l}0 \\
0 \\
0 \\
\end{array}$ & 聯 & $\begin{array}{l}53 \\
41 \\
12\end{array}$ & 曻 & $\begin{array}{l}0 \\
0 \\
0\end{array}$ & 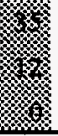 & $\begin{array}{l}6 \\
0\end{array}$ & 森 & $\begin{array}{l}18 \\
24\end{array}$ & 䋑 & $\begin{array}{l}53 \\
53\end{array}$ & 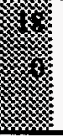 & $\begin{array}{l}48 \\
48\end{array}$ & 殮 & $\begin{array}{l}6 \\
6\end{array}$ & 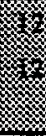 \\
\hline
\end{tabular}

$a=$ symptom experienced on day of survey while at work.

$b=$ experienced significant complaint or condition experienced at work during day of the survey.

$c=$ symptom frequently experienced during last four weeks while at work.

$d=$ significant complaint or condition experienced at work during previous four weeks.

$e=$ have frequent symptoms that improve when away from work. 


\section{Health Symptoms and Environmental Complaints in Percent, 26 NIOSH School Health Hazard Evaluation Reports, 1983 - 1994}

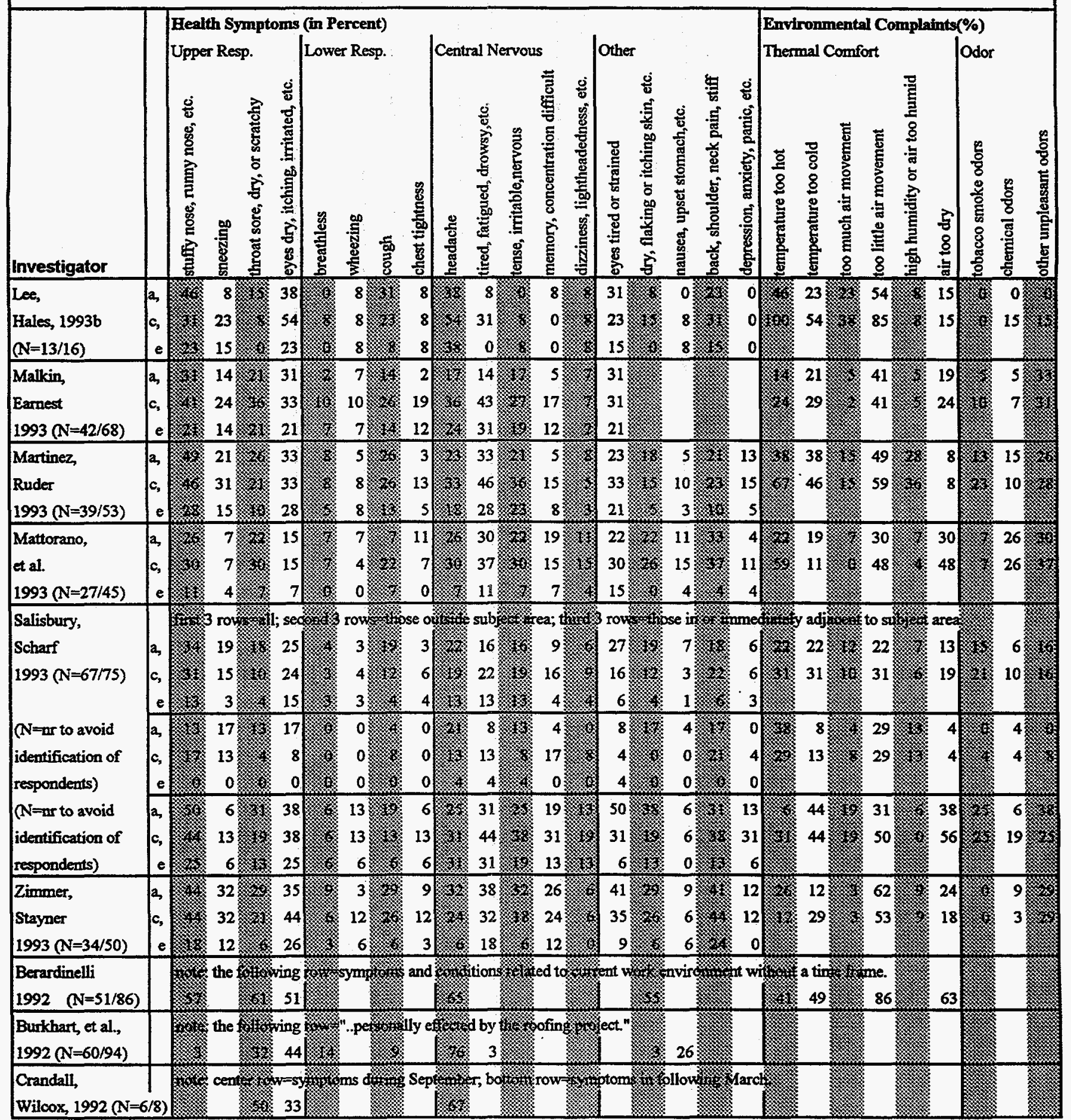


Health Symptoms and Environmental Complaints in Percent, 26 NIOSH School Health Hazard Evaluation Reports, 1983 - 1994

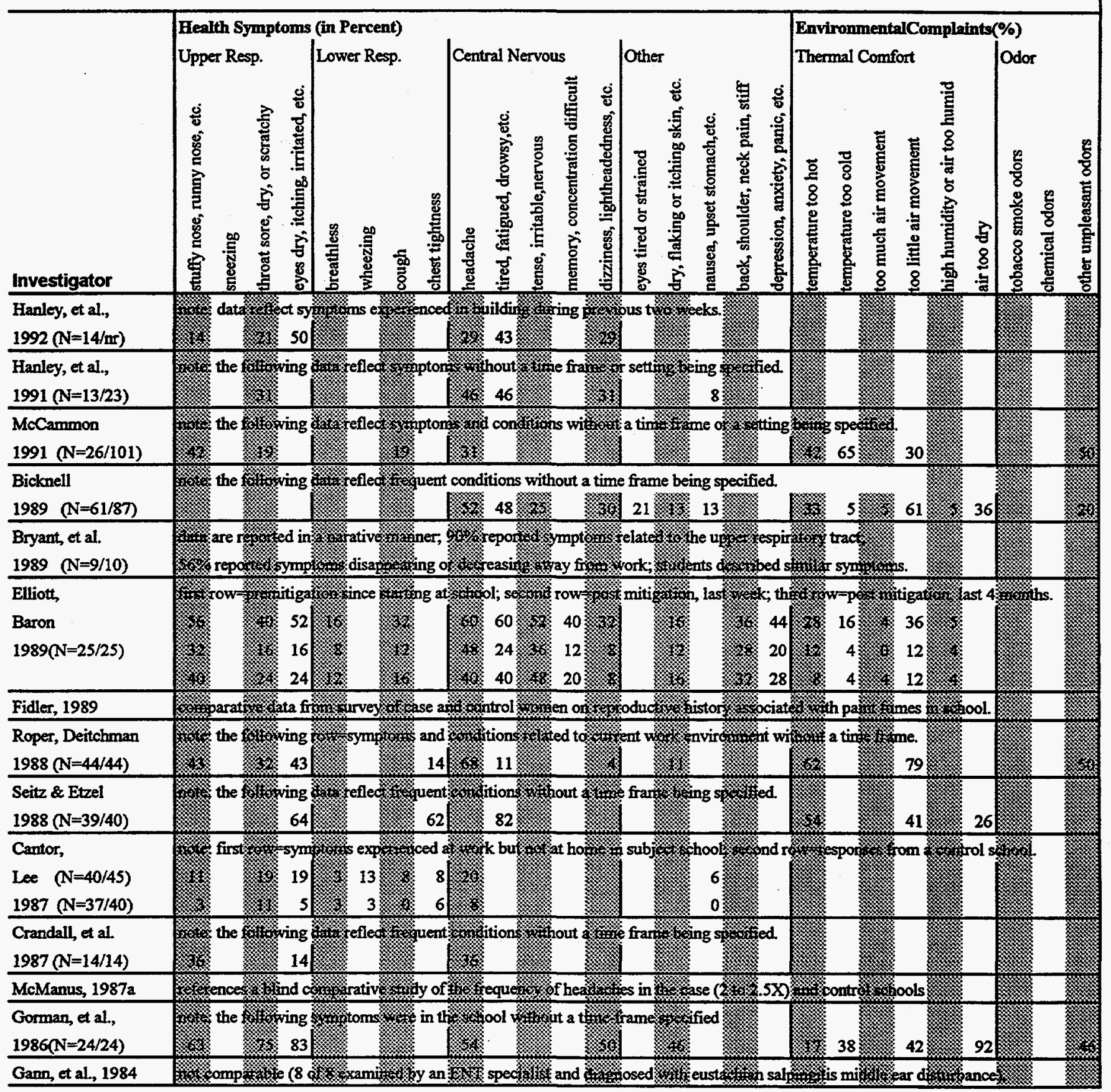


Health Symptoms and Environmental Complaints in Percent, 26 NIOSH School Health Hazard Evaluation Reports, $1983-1994$

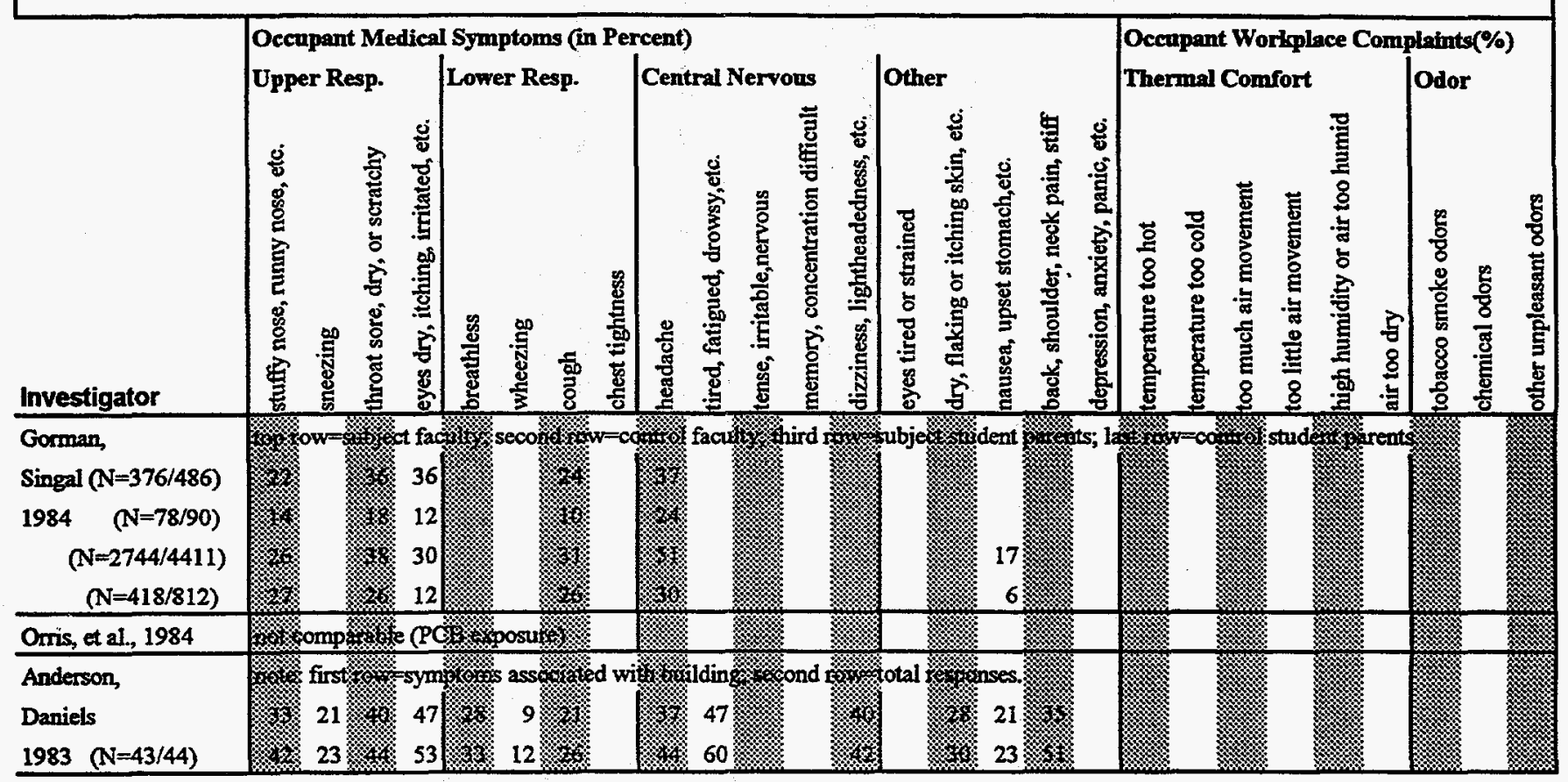


Appendix C:

Reported Building Problems, NIOSH School Health Hazard Evaluation Reports, 1981 - 1994

\begin{tabular}{|c|c|c|c|c|c|c|c|c|c|c|c|c|c|c|c|c|c|c|c|c|c|}
\hline Inveatigator & 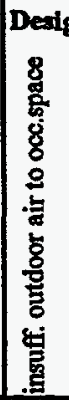 & 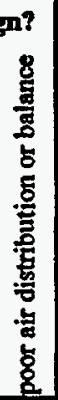 & 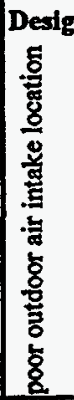 & 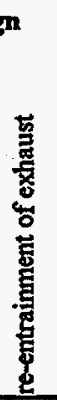 & 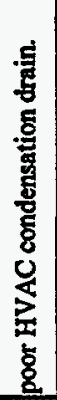 & 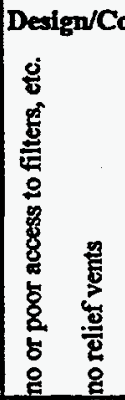 & 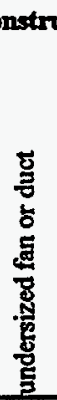 & 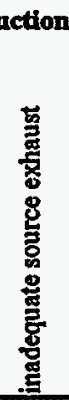 & 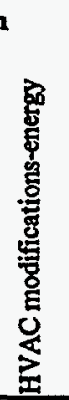 & 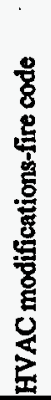 & 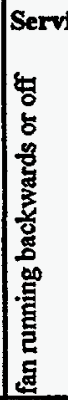 & $\begin{array}{l}\text { 多 } \\
\text { 总 } \\
\text { 总 }\end{array}$ & 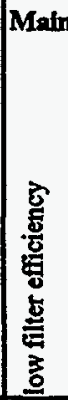 & 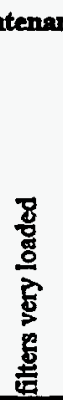 & 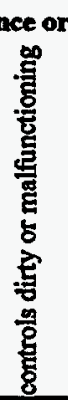 & 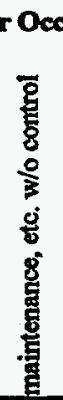 & 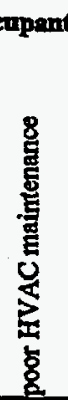 & 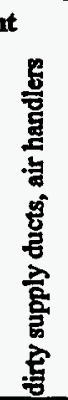 & 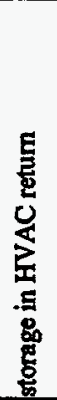 & 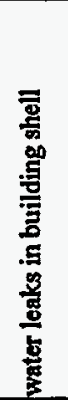 & 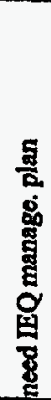 \\
\hline $\begin{array}{l}\text { Berardinelli, } 1994 \\
\text { Donovan, } 1994 \\
\text { Blade \& Behrens, } 1993\end{array}$ & 鄗 & $x$ & 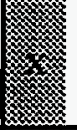 & $\mathrm{x}$ & 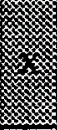 & $\mathbf{X}$ & & & $\mathbf{x}$ & & & 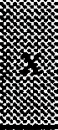 & $\begin{array}{l}x \\
x\end{array}$ & & & & $\mathbf{x}$ & & & & $x$ \\
\hline $\begin{array}{l}\text { Burkhart \& Jennison, } 199 \\
\text { Burr, et al., } 1993 \\
\text { Daniels \& Cornon, } 1993\end{array}$ & 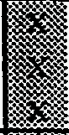 & $\mathrm{X}$ & & $\begin{array}{l}X \\
X\end{array}$ & & $\mathbf{x}$ & $\underline{x}$ & & & & $\begin{array}{l}\mathrm{X} \\
\mathrm{x}\end{array}$ & & $\begin{array}{l}x \\
x\end{array}$ & & $x$ & & $\mathbf{x}$ & & & & $\begin{array}{l}x \\
x\end{array}$ \\
\hline $\begin{array}{l}\text { Decker, } 1993 \\
\text { Deitchman \& Fajen, } 1993 \\
\text { Kicfer, et al., } 1993 \\
\end{array}$ & 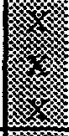 & $\mathbf{x}$ & & $x$ & & & & 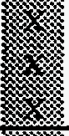 & & & & & & & & & $\mathbf{x}$ & & $\mathbf{X}$ & & $\mathrm{x}$ \\
\hline $\begin{array}{l}\text { Kimes \& Bresler, } 1993 \\
\text { Lee \& Hales, 1993a } \\
\text { Lee \& Hales, 1993b }\end{array}$ & 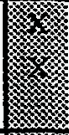 & $\mathrm{x}$ & $x$ & & & & & & & & & & & & $\bar{x}$ & & $\mathrm{x}$ & & & & \\
\hline $\begin{array}{l}\text { Malkin \& Earnest, } 1993 \\
\text { Martinez \& Ruder, } 1993 \\
\text { Mattorano, et al., } 1993\end{array}$ & 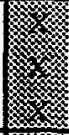 & $\begin{array}{l}X \\
X\end{array}$ & & & & $\mathrm{x}$ & & 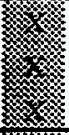 & & & & & $\mathbf{x}$ & & $\begin{array}{l}X \\
X \\
\end{array}$ & & $\begin{array}{l}X \\
X \\
X\end{array}$ & & & & $x$ \\
\hline $\begin{array}{l}\text { Salisbury \& Scharf, } 1993 \\
\text { Sim \& Bryant, } 1993 \\
\text { Zimmer \& Stayner, } 1993\end{array}$ & 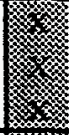 & & & $\mathrm{x}$ & & & & X. & & & & & $\bar{x}$ & & $\mathrm{x}$ & & $\begin{array}{l}X \\
X\end{array}$ & & & 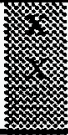 & $\mathrm{x}$ \\
\hline $\begin{array}{l}\text { Berardinelli, } 1992 \\
\text { Blade, } 1992 \\
\text { Burkhart, et al., } 1992 \\
\end{array}$ & 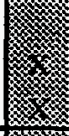 & $\begin{array}{l}\mathrm{X} \\
\mathrm{X} \\
\mathrm{X} \\
\end{array}$ & & $\mathrm{X}$ & & & & & & & & & $\mathbf{X}$ & & $\mathrm{X}$ & & & & $x$ & & $\mathbf{x}$ \\
\hline $\begin{array}{l}\text { Crandall \& Wilcox, } 1992 \\
\text { Honley, et al, } 1992 \\
\text { Kelly, 1992a }\end{array}$ & 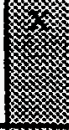 & $\mathrm{X}$ & & & & $\mathbf{X}$ & & & $\mathbf{x}$ & & & & $\mathrm{x}$ & & $x$ & & & & & 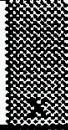 & $\mathbf{x}$ \\
\hline $\begin{array}{l}\text { Kelly, 1992b } \\
\text { Martinez, et al, } 1992 \\
\text { Hanley, et al., } 1991 \\
\end{array}$ & 8 & $\begin{array}{l}\mathbf{X} \\
\mathbf{X} \\
\end{array}$ & & & & & & & & & & & $\mathbf{X}$ & & $\mathbf{x}$ & & & & & & $\mathrm{x}$ \\
\hline $\begin{array}{l}\text { MoCammon, } 1991 \\
\text { Alamaguer, } 1989 \\
\text { Bicknell, } 1989\end{array}$ & 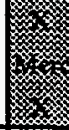 & $\begin{array}{l}x \\
x \\
x\end{array}$ & & & 6 & & & $63 x$ & $\mathbf{x}$ & & & & & & & & $x$ & 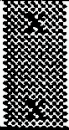 & & x & \\
\hline $\begin{array}{l}\text { Bicknell, et al., } 1989 \\
\text { Bryant, et al., } 1989\end{array}$ & 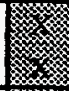 & & & & 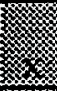 & & & & & & & & & & & & $x$ & & & & \\
\hline Elliott \& Baron, 1989 & 㥕妙 & $\mathrm{x}$ & & & & & & & & & & & & & & & $x$ & & & & \\
\hline
\end{tabular}


Appendix C (continued):

Reported Building Problems, NIOSH School Health Hazard Evaluation Reports, 1981 - 1994

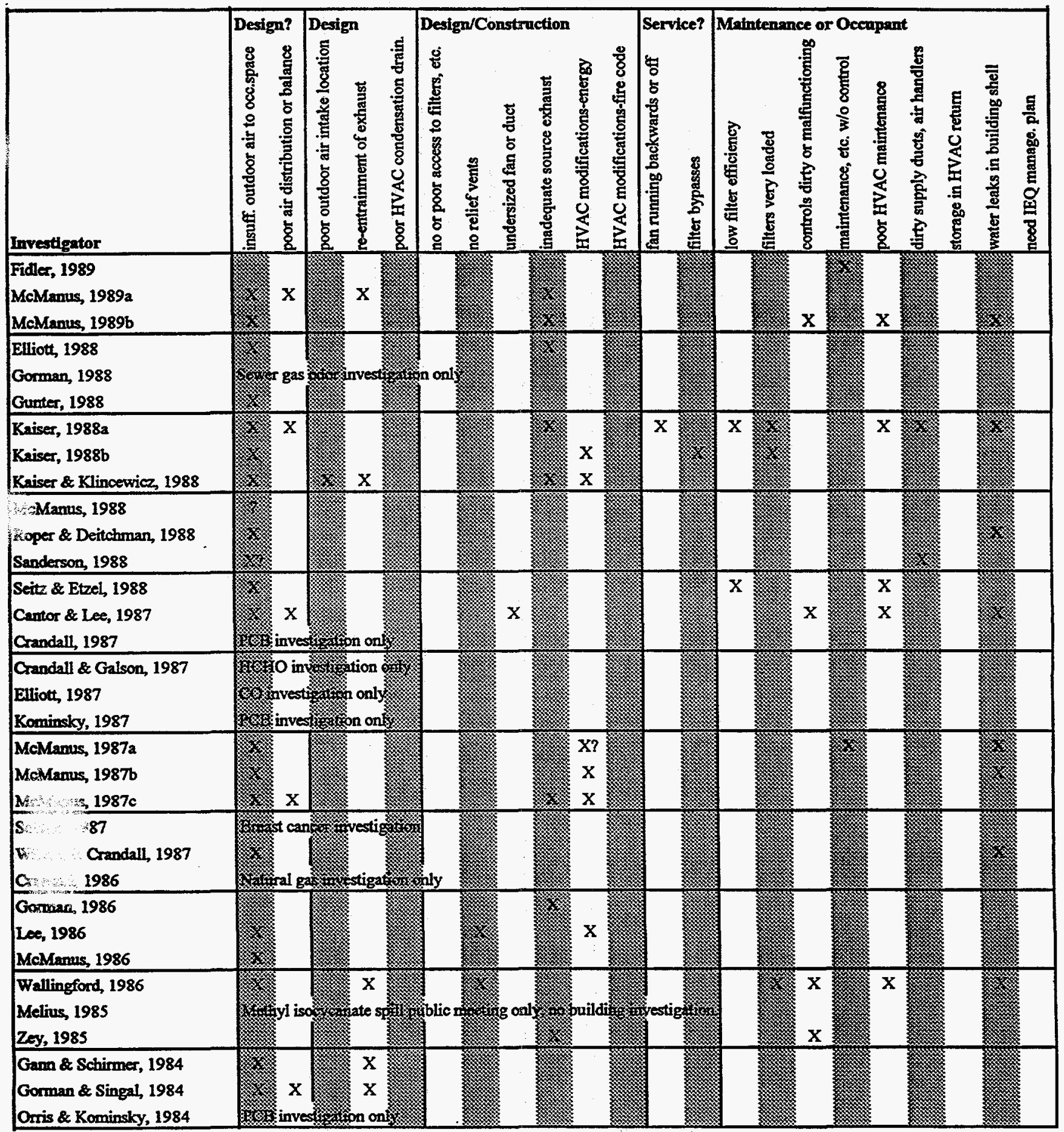


Appendix C (continued):

Reported Building Problems, NIOSH School Health Hazard Evaluation Reports, 1981 - 1994

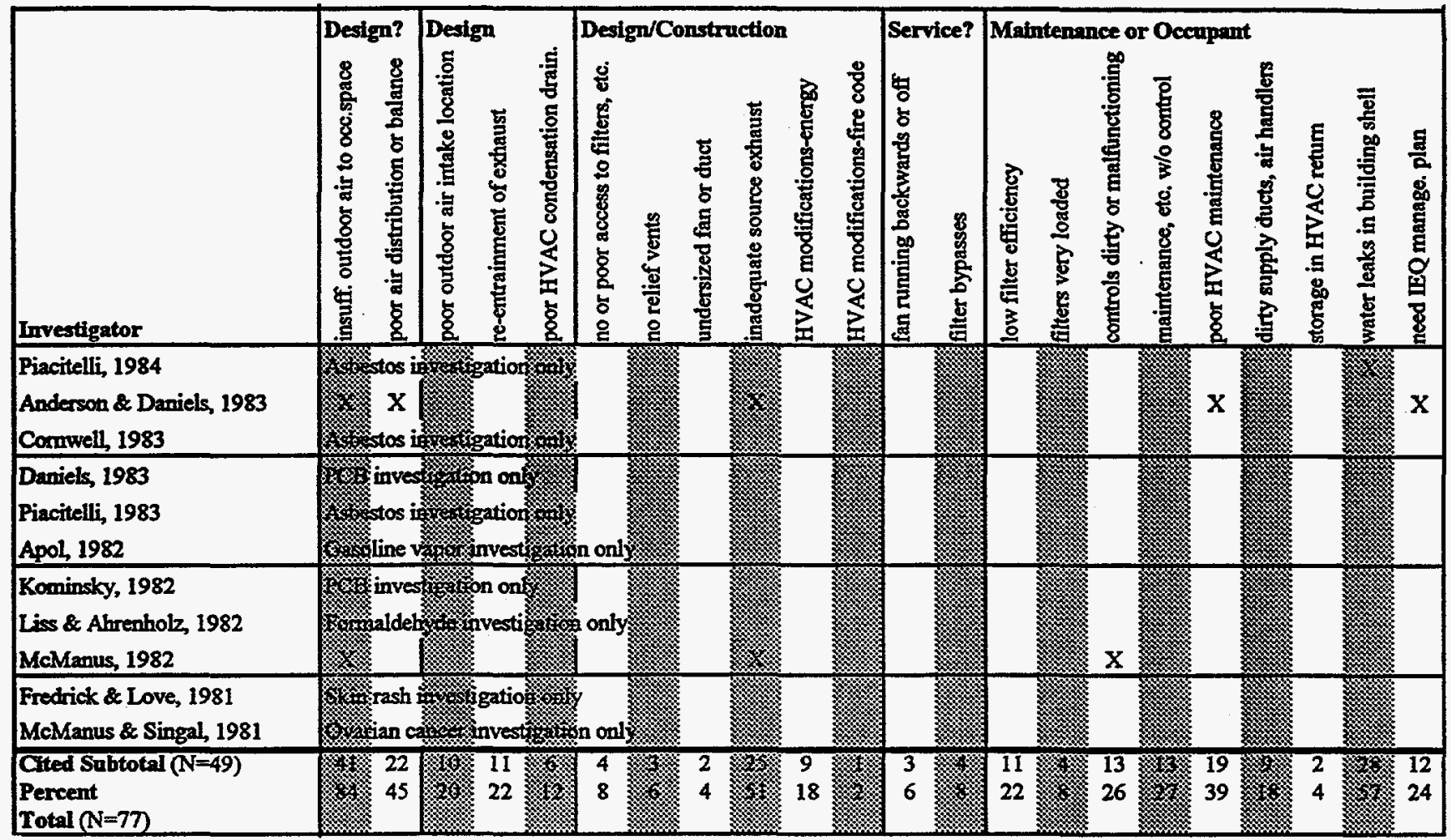

